\title{
The Timing of Early Interventions and Child and Maternal Health
}

J onas Lau-J ensen Hirani, Hans Henrik Sievertsen and Miriam Wüst

Discussion Paper $20 / 720$

30 March 2020

BRISTOL

Department of Economics

University of Bristol Priory

Road Complex Bristol BS8

1TU

United Kingdom 


\title{
The Timing of Early Interventions and Child and Maternal Health
}

\author{
J onas Lau-J ensen Hirani; Hans Henrik Sievertsen ${ }^{\dagger}$ and Miriam Wüst ${ }^{\ddagger}$
}

Version: March 23, 2020.

\begin{abstract}
What is the impact of timing of early-life investment policies on child and maternal health? Exploiting variation from a 2008 Danish nurse strike, we study this question in the context of universal nurse home visiting. We show that early but not later strike exposure increases child (and mother) general practitioner contacts in the first four years after childbirth. Mothers, who forgo an early nurse visit (rather than a later one), have a higher probability of mental health specialist contacts in the first two years after childbirth. We highlight two channels for these results, screening and information provision: We show that nurses perform well in identifying maternal mental health risks during early home visits in control years (likely preventing longer-term problems). Finally, we show that first-born children and children of parents without a health-related education drive our results. A stylized calculation confirms that short- run health benefits from early universal home visiting outweigh costs.
\end{abstract}

J EL Codes: I11, I12, I14, I18, I21

Keywords: Early-life health, early interventions, nurse homevisiting, parental invest- ments

*Department of Economics, University of Copenhagen and The Danish Center for Social Science Research

(VIVE). Herluf Trolles Gade 11, 1052 Copenhagen, email: jjh@vive.dk.

${ }^{\dagger}$ Department of Economics, University of Bristol and The Danish Center for Social Science Research (VIVE). Priory Road Complex, Priory Road, Bristol BS8 1TU, UK, email: h.h.sievertsen@bristol.ac.uk.

‡Corresponding author: University of Copenhagen, Center for Economic Behavior and Inequality (CEBI),

Department of Economics and The Danish Center for Social Science Research (VIVE). Øster

Farismagsgade 5, 1353 Copenhagen, email: miriam.w@econ.ku.dk., phone: +45 35321365

We gratefully acknowledge financial support from the Innovation Foundation Denmark grant 515500001B. The Copenhagen City Archives generously provided the data on nurse home visiting in the municipality of Copenhagen. We thank Boel Leth Emanuel (municipality of Copenhagen) for valuable input on the data. We thank Søren Leth Pedersen, Maya Rossin-Slater, Christine Valente, Stephanie Vincent Lyk-Jensen and seminar participants at briq (Bonn), SOFI (Stockholm), CEBI (University of Copenhagen), Copenhagen Business School, the NBER Children's Program Meeting 2019, the Danish Ministry of Health, CINCH Essen and at the 2019 EALE conference for helpful comments. 


\section{Introduction}

This paper studies the importance of the timing of early-life public health investments for child and maternal health. Evidence on this question is sparse but instrumental for policy: In the light of mounting evidence on the importance of early interventions for the shortand long-run health and human capital of children, policy decisionsin many settings evolve around central features of early-life investment program, such as their timing.

Westudy an investment programin Denmark, whereall newfamilies areeligiblefor up to five universal homevisits by a trained nurse during the first year of a child'slife. Thesevisits focus on health screening, the provision of information, and counseling to new parents (on topics such as infant feeding, infant development and child-parent interactions). Additionally, nurses referfamilies with identified needs to other health care professionals, suchas general practitioners (GPs) or hospitals.

To identify the impact of timing of nurse home visiting (NHV), we exploit exposure to a 2008 nurse strike for families with children born in the seven months prior to the strike. Duringthe61daysofthestrike, thevastmajority of non-emergencynursecarewascancelled. Importantly, cancelled visits were not rescheduled. Weexploit the strike-induced variation in nurse home visits, together with information on children born in non-strike years in a difference-in-differences design.

To make our study feasible, we collected individual-level data on program take-up (number and timing of nurse visits) in largest municipality in Denmark (Copenhagen) and linked these records to administrative data on family background and health outcomes. ${ }^{1}$ Thus we break new grounds by compiling data on actual program take-up (the policy-relevant margin in a universal program), which allows us to be specific about theintensity of the treatment that westudy. Thelink to administrative dataallows us to analyzethe credibility of our empirical design (by assessing the compliance with the nurse strike across different groups of families).

\footnotetext{
'While Scandinavia is well-known for its high-quality administrative data in many domains, national administrative data sources typically lack individual-level data on municipal programs-such as NHV, nurseries or preschools.
} 
In our first set of results, we show that, while children born in the 210 days prior to the strikeonaveragemissed onescheduled postnatal nursevisit, dependingontheirdateofbirth relative to thestrike, children had a different ageat theforgonevisit. In Copenhagen, nurses only performed ten percent of the homevisits that weobservein thesameweeks in theyears prior to and after thestrike. Exploiting themerged nurserecordsand administrativedata on family background, we show that the strike impacted families similarly across characteristics, likely observed by nurses. This finding illustrates the broad coverage of the strike in the population and relieves concerns that nurses to a large degree chose the families that would forgo their visit. Additionally, we show that (given that all children were born before the onset of the strike) other aspects of carearound birth (such as prenatal midwife contacts or hospital admissions at birth) were not impacted by children's strike exposure.

Moving on to our reduced form analysis of the impact of strike exposure at specific ages, we show that exposure during the initial months of a child's life is relatively more influential for child and maternal health than later exposure. We measure health by the uptake of additional medical care: Children, who were born in the two to three months up to the strike, and thus were likely to miss the early nurse visits due to the strike, havemore contacts to general practitioners (GP) in the first four years of life than children, who were older at their exposure to the strike. This result holds for both regular an emergency GP contacts (the latter not being performed by the family's regular GP and outside GP office hours). Moreover, ourresultsforyearlymeasures ofGP contactsconfirm thisfinding, i.e. our results are not driven by a closer relationship with the family GP or a substitution of nurse visits with GP visits during the strike period. ${ }^{2}$ Wealso find suggestive evidence for a higher probability of hospital contacts in the second year of the child's life for early strike-exposed children. Thisfindingfurthersubstantiatesthat ourresultsforan increased uptakeof health care reflect children's underlying health.

We also study maternal health care usage as a consequence of strike exposure. First,

\footnotetext{
${ }^{2}$ Our main outcome measures of GP contacts exclude preventive care contacts to the GP, which we study separately.
} 
we find that mothers, who are likely to forgo an early nurse visit due to the strike, have more GP contacts in the first four years after their child's birth. Second, wefind suggestive evidence for early strike-exposed mothers being more likely to haveat least one contact with a psychologist or psychiatrist in the first two years of the child's life. This finding suggests that early strike-exposed mothers (who thus lack a nurse visit focusing on earlyscreening formental health issues) end up receivingmorespecialist treatment. Whilemissingan early nurse visit initially (and mechanically) may result in fewer mothers being referred to other specialists, our findings suggest that (in the longer run) early strike exposure leads to an increased likelihood of mothers experiencingmental health problems that requirespecialist attention. Thus our finding is in line with recent studies documenting the importance of different aspects of the early home environment (in our case the early detection and prevention of severeproblems) formaternal postpartum mental health (Butikofer et al., 2018; Baranov et al., 2019; Persson and Rossin-Slater, 2019).

Having established health effects of missing an earlynursevisit, weconsider twopossible mechanisms by exploring theroleof screening and information. First, earlynursevisits may help to identify adverse conditions in a timely fashion and prompt additional treatments. Weuse data from thenon-strike exposed control period to show that, at initial visits, nurses typically record issues related to feeding, child physical health and maternal well-being. In control year data, these initial registrations correlatewith both futurenurse registrations of health issuesand theincreased useof health careservicesamongchildren, aswell as thelikelihood of future maternal psychiatric contacts. These correlations suggest that early nurse visits act as an important screening device to identify vulnerable children and mothers. In absence of early nursevisits, for themarginal child and mother, health problems may go unnoticed for alonger period and contribute to longer-term adverse health effects. Our results for theimpactof earlystrike-exposureon maternal contactstopsychologists or psychiatrists are in line with this reasoning. Moreover, given documented correlations of maternal postnatal mental health and child-parentinteractionsand child development(Cooperand Murray, 
1998; Lovejoy etal., 2000; Paulson et al., 2006; Wachs etal., 2009), screeningfor postnatal maternal well-being issues may be one driver also for impacts of early NHV on children.

Second, in theabsence of early nursevisits, parents maylackspecificinformation, which is typically provided by nurses and is difficult to replace by other and less specialized health care providers, such as GPs. Moreover, information and counselingprovided bynurses may impact parents' investment behaviors, such as breastfeeding, parent-child interactions or uptake of other preventive care. To examine the relevance of this channel, we study the impact of strike exposureamong children across different backgrounds. Wefind suggestive evidencethathigherparity children and children of parents with an educational background in a health-related field (nurses, midwives, doctors and pedagogues) are less affected bystrike exposure than their first-parity and not health-educated counterparts, respectively. At the sametime, wefind nostrongand unambiguous evidenceforasocio-economicgradientinthe effect of early strike exposure. These findings indicate that at least part of the beneficial effect of early NHV runs through a specific information channel. While we study parents' participation in the vaccination and preventive care programs (as our main measures of parental investment behaviors), we do not detect a strong impact of the timing of nurse visits in our design. However, these analyses are constrained by power issues.

Our stylized analysis of the direct costs and benefits of early nurse visits relative to later visits (based on alimited set of outcomes from the domain of health and thus ignoring other potential benefits of earlier nurse visits) shows that immediate benefits (in terms of averted child and mother GP visits) clearly outweigh costs (with 331-426 EUR). Thus our findings indicatethat early universal visits area cost-effectiveintervention to promotechildren's and mothers' health in settingsthat resembletheDanish health caresystem. Given our findings, universal child programs should havea strongfocus on theinitial period of family formation after the birth of a child.

Our work contributes to a large literature documenting causal links between childhood experiences-shocks and exposureto policies - and later life outcomes (for an overview see 
Almond and Currie, 2011; Almond et al., 2018). Wemake three contributions: First, when studyingthecausal effects of early-lifeinvestmentprograms (such asnursehomevisiting, or childcareand early education provisions), themajority of work has considered the effects of program exposure. However, we still lack insights on thecausal effects of important design aspects of early-life investment policies, such as timing or intensity. In our paper, rather than studying the margin of program exposure, we consider the so far largely unexplored impacts of the relative timing of access to early-life health programs. Our study extends earlier work by Kronborg et al. (2016), who study mothers giving birth during and shortly prior to thenurse strikeand only find short-lived effects of strike exposure on thetake-up of GP care for children. However, in their paper all strike-exposed mothers and children forgo the earliest home visits (the ones that we show are influential) and vary in their access to various treatments: prenatal midwife consultations, hospital stays after birth and the early postnatal nursevisits. ${ }^{3}$

Second, a large share of the work on early-life investment policies has been set in a U.S. context and as a consequence has considered targeted programs. ${ }^{4}$ Existing work on NHV has primarily focused on contemporary targeted programs as well (Olds et al., 1986, 1998, 2002; Vaithianathan et al., 2016; Doyle et al., 2015; Sandner et al., 2018; Sandner, 2019). ${ }^{5}$

\footnotetext{
${ }^{3}$ Strike-exposed mothers in their analysis received less pre- and postnatal care: Mothers, who gavebirth during the strike received fewer prenatal midwife consultations, were more likely to be discharged from hospital on the day of birth, and received fewer nurse home visits. Mothers, who gave birth in the two weeks prior to the strike had higher probability of not receiving the initial nurse visit but were unaffected with respect to the access of prenatal care. Mothers, who gave birth earlier (two weeks to two months prior to the strike) were unaffected with respect to the prenatal care offers, hospital care around birth but had an increased probability of a canceled second nurse visit. Given that all mothers in the sample lack the early home visits after birth, our analysis identifies a different margin of treatment (focusing only on the importance of timing of postnatal care). Moreover, while Kronborg et al. (2016) cannot link data on NHV to data on family background and health outcomes, we perform a complier analysis, i.e. assess the "coverage" of strike exposure in the population of families. Finally, we both analyze a broader set of relevant outcomes (including maternal well-being) and the potential channels for our main results.

${ }^{\mathbf{A}}$ Examples include RCT studies on the targeted Perry Preschool Program, the Abecedarian project (Heckman et al., 2013; Conti et al., 2016), and observational studies on the short- and long-run impact of Head Start (Currie and Thomas, 1995; Garces et al., 2002; Masse and Barnett, 2002; Schweinhart et al., 2005; Belfield et al., 2006; Ludwig and Miller, 2007; Anderson, 2008; Deming, 2009; Heckman et al., 2010a,b; Carneiro and Ginja, 2014; Campbell et al., 2014; García et al., 2016; De Haan and Leuven, 2016; García et al., 2017; Thompson, 2017). Also in a US context, there are a few examples for studies considering universal provision of preschool (see, for example, Cascio, 2009, 2015).

${ }^{\mathbf{5}}$ Existing evidence suggests that targeted NHV can be effective in improving a large range of short- and
} 
However, many countries offer universal programs and the results from studies on targeted programs do not easily generalize to settings with universal implementation. Our studyis the first to analyze the causal impacts of a contemporary universal program. ${ }^{6}$ Evidence on theimpact of universal health programsand their design is instrumental for policy design in many settings.

Third, weshed light on two relevant mechanisms for theimpact of timing of NHV on child and mother health: Screening (and potential referral of families to other health professionals) and information (e.g., about infant feeding or age-specific child-parent interactions). This information may matter in its own right (i.e., it may be new to parents) or modify parental beliefs (i.e., it may help parents to update their reading of information that they haveaccess to). Recent research documents theimportance of parental beliefs-their interpretation of rather than their pure awareness of information-for both child health outcomes and parental investmentbehaviors (see, for example, Cunhaetal., 2013; Attanasioetal., 2015; Bonevaand Rauh, 2018; Biroli et al., 2018). Our unique data allow us to explore the question of which elementsmatterin NHVbyusingspecificnurseregistrationsand theheterogeneity of effects of NHV across different types of parents. While we cannot formally distinguish whether nurses provide new knowledge to parents or modify their beliefs about its importance, we

long-run child outcomes and points to the role of the structure of the programs and the qualifications of service providers (for an overview on existing studies and a discussion of the impact of provider quality, target group and program features, see Almond and Currie, 2011): Focusing on the targeted Nurse Home Visiting Partnership program in the US, Olds et al. $(1986,1998,2002)$ show that high-frequency pre- and postnatal visits for at-risk mothers conducted by trained nurses reduced child abuse, decreased children's emergency room visits and their criminal convictions in adolescence. Similarly, Vaithianathan et al. (2016) provide evidence from New Zealand showing that targeted nurse visits reduced infant mortality and increased both vaccination rates and children's participation in early childhood education. Doyle et al. (2015) study the targeted Preparing for Life-program in Ireland and find some positive effects on child health (such as asthma issues) and accidents. Sandner et al. (2018) and Sandner (2019) document that the German implementation of the "Pro Kind" program, a home visiting program for low-income first-time mothers, did not impact child health but had impacts on mothers in the RCT: treated mothers reported lower levels of depression. In the longer run, the program increased fertility and decreased maternal labor supply. Work from developing country contexts highlights the important role for child development and long-run outcomes that intensive home visiting can play (Attanasio et al., 2014; Gertler et al., 2014).

'Another line of research has documented positive long-run impacts of the historical introduction of universal NHV in Scandinavia of the 1930s and 40s (Wüst, 2012; Hjort et al., 2017; Bhalotra et al., 2017; Bütikofer et al., 2019). All existing evidence on the causal short- and long-run effects of NHV in Scandinavia comes from historical data and considers the extensive margin of treatment exposure. These studies have documented positive long-run effects on the health and socio-economic outcomes of exposed cohorts. 
find that the timely provision of both components of NHV (information, screening) most likely are important for the impacts of the program.

Thepaper proceeds as follows: Section 2 providesinformation on theinstitutional background, the 2008 nurse strike and the data sources that we use. Section 3 presents our empirical strategyand discusses theidentifyingassumptions. Section 4 presentsdescriptive and main results and examines their robustness and heterogeneity. Section 5 performs a simple cost-effectiveness analysis. Finally, section 6 concludes.

\section{Background and Data}

\subsection{Institutional Background: Pre and postnatal care in Denmark}

In Denmark, pre- and postnatal care is provided in the public health care system and all residents have access to care free of charge. Midwives and general practitioners provide prenatal care that consists of regular consultations during pregnancy. ${ }^{7}$ The majority of uncomplicated births are midwife-assisted and takeplacein public hospitals only. Hospital births account for around 98 percent of all births.

After hospital discharge, the 98 municipalities are responsible for providing postnatal care in the NHV program. While there is some variation in municipal service levels, the Danish National Board of Health (DNBH) issues guidelines and regulations regarding the number, timing and content of nurse visits. As such, NHV consists of a basic package of services offered to all families with a newborn. Additionally, municipalities can choose to offer supplementary services targeted at specific populations of mothers and children. Those services includeadditional homevisits or other services. ${ }^{8}$ Moreover, Danish GPsprovidethe child preventive health program and administer recommended vaccines in the vaccination program. The Danish preventive care schedule offers eight (voluntary) GP health checksfor

\footnotetext{
${ }^{7}$ The universal offer consists of 4-7 midwife consultations, 3 GP consultations and 2 ultrasound scans Sundhedsstyrelsen (2007). At-risk pregnancies receive additional care.

${ }^{8}$ These services can include offers such as group interventions, interventions targeted at young parents or parents with specific health issues, or interventions specifically directed at fathers.
} 
all children: at around five weeks, at around five months, and yearly for children aged one through sixyears(Sundhedsstyrelsen, 2007). Additionally, GPsofferonepostpartum health check for mothers. In the first year of the child's life, the Danish vaccination program for children consists of three rounds, at three, five and twelve months, respectively. ${ }^{9}$

\subsection{NHV in Copenhagen}

Ourstudy focuses on NHV in Copenhagen, thelargest municipality in Denmark with around 500,000 inhabitantsandaround 8-10,000yearlylivebirths. Appendix TableA1presentsthe main features of NHV in Copenhagen. The default number of universally-offered visits in the program is four: an initial visit shortly after birth (A visit), a two month visit (B visit), a four month visit and an eight month visit ( $\mathrm{C}$ and $\mathrm{D}$ visit). Infants, who are discharged after short hospital stays can receive two A visits. ${ }^{10}$ Moreover, nurses can provideadditional targeted visits to children and families with identified needs at their discretion. The timing of these additional visits is flexible. Finally, the municipality offers optional visits that are available on the request of parents (visits at ages 1.5 and three years).

Home visits usually last between 30 minutes and one hour. During the visits, nurses provideinformation and counseling to parents and examine theinfant. Thevisits take their point of departure from a general set of main topics (which are of different importance at different ages of the child) outlined in the national guidelines for NHV. At the same time, those guidelines explicitly state that nurses should focus on the needs of the specific family. Thus nurses havelarge discretion to focus their timein the family homeon what they regard as most important. While some topics, typically related to screening (such as tests for certain infant reflexes, monitoring of maternal postnatal well-being and the monitoring of

\footnotetext{
${ }^{9}$ Each round consists of two separate vaccinations. First, a combined vaccination to immunize against diphtheria, tetanus, pertussis, polio and hib infection. Second, a pneumococcus bacteria vaccination to prevent infant meningitis. We focus in this paper on the vaccinations given in the first year of life but the vaccination program continues with a number of other vaccinations throughout childhood and adolescence.

${ }^{10}$ Especially for higher parity births, discharge on the day of birth is not unusual in Denmark: Among uncomplicated births in our sample, 58 percent of mothers are discharged with their infant on the day of birth.
} 
child weight and height), are part of visits to all families, other topics are only covered if the family or the nurse find them relevant.

Given thevariation in families' needs, nurse registrations are of similarvariability: Table 1illustrates the main topics that structure the universal nurse visits in the child's first year of life (A-D visits in Copenhagen) and which registrations nurses can make. Importantly, domains that are covered in each visit such as infant feeding have age-specific items that nurses can make registrations on (such as "issues with establishment of breastfeeding" or "issues with the introduction of solid food").

To illustrate the typical content of the nurse visits, Figure 1 presents nurse registrations made by Copenhagen nurses during or shortly after their home visits to families fromour control cohort. ${ }^{11}$

Weaggregate nurse registrations into broader categories and plot for each of those categories the share of families with a recorded issue by type of visit (conditional on having received the visit). As thefigureillustrates, the visits focus on different domains: Whilethe share offamilies with "registrations of an issuein anydomain" remains ratherstableoverthe course of thefourvisits, thereareimportant differences especially when comparing the first two and final two universal visits. During the initial visits, nurses typically record issues related to maternal mental well-being and infant feeding issues. The former is very well-defined, mother-specific and highlycorrelated for women across visits. Thelatteris child-related but ratherunspecificin its content. Whileregistrations on feedingissuesarecommon duringthe initial visits, nurseobservationsand registrations on child developmental problems (a summary measureof various dimensions of child development) aremoreprevalent in thevisitsat aroundfourand eightmonths. Usingthischaracterization of thecompositenursetreatment, we will return to the importance of different aspects of the treatment in section 4.4.

\footnotetext{
"As we will detail in section 2.3, we use data on several cohorts of children and mothers, one of them exposed to the nurse strike. In Figure 1, we focus on non-strike exposed children and mothers as strikeexposed families naturally lack nurse registrations.
} 
Table 1Overview on main topics at nurse visits and options for nurse registrations in the municipality of Copenhagen.

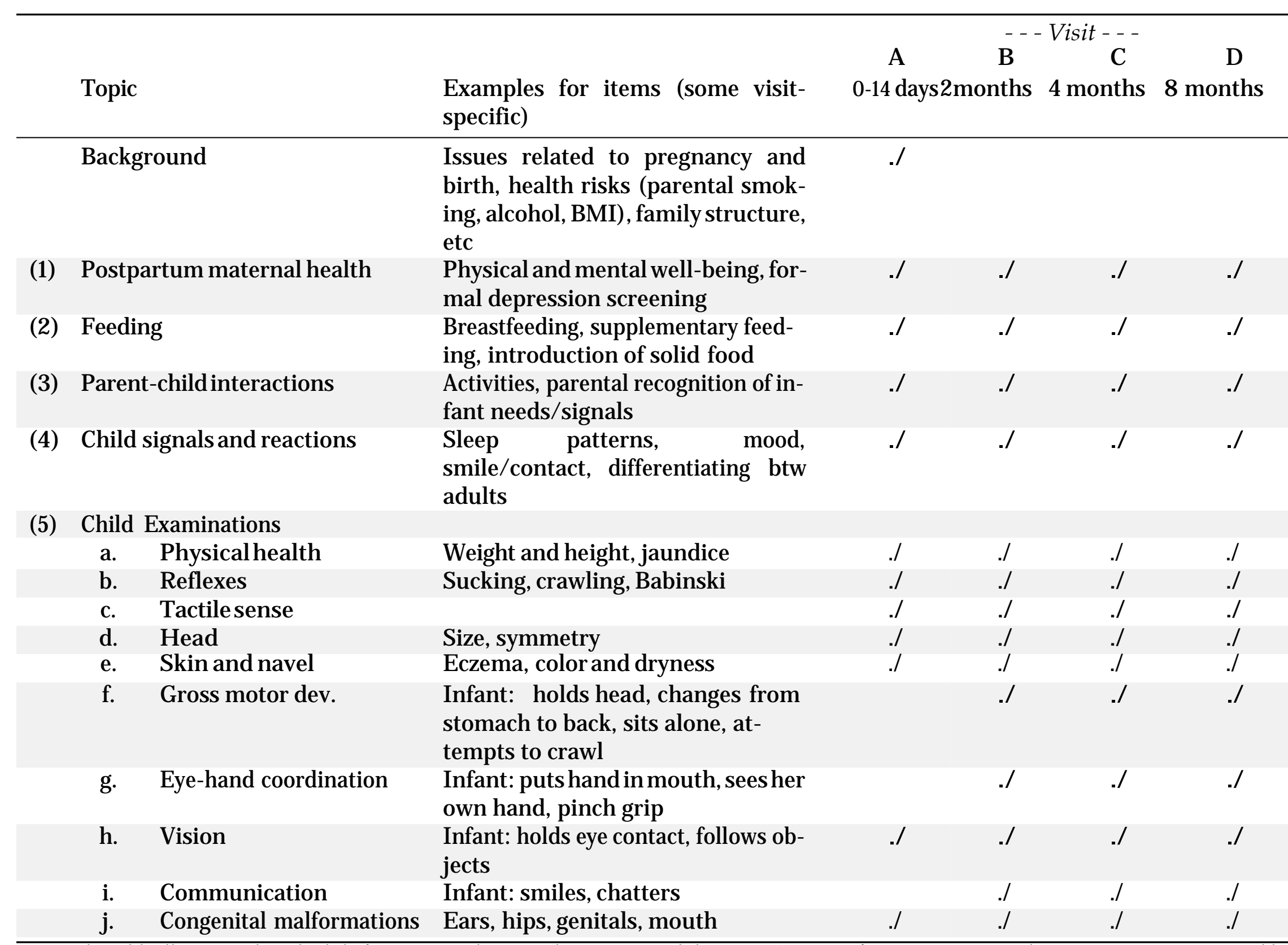

Notes: The table illustrates the schedule for topics at the given home visit and the nurses' options for registrations in the registration system used by nurses in Copenhagen in the period that we study. Visits A-D refer to the type of the four scheduled universal visits. Additionally, nurses can offer a targeted pregnancy visit (around week 30 of the pregnancy), visits based on identified needs in the family, and a visit at age 1.5 and 3 years (on parental demand), respectively. 


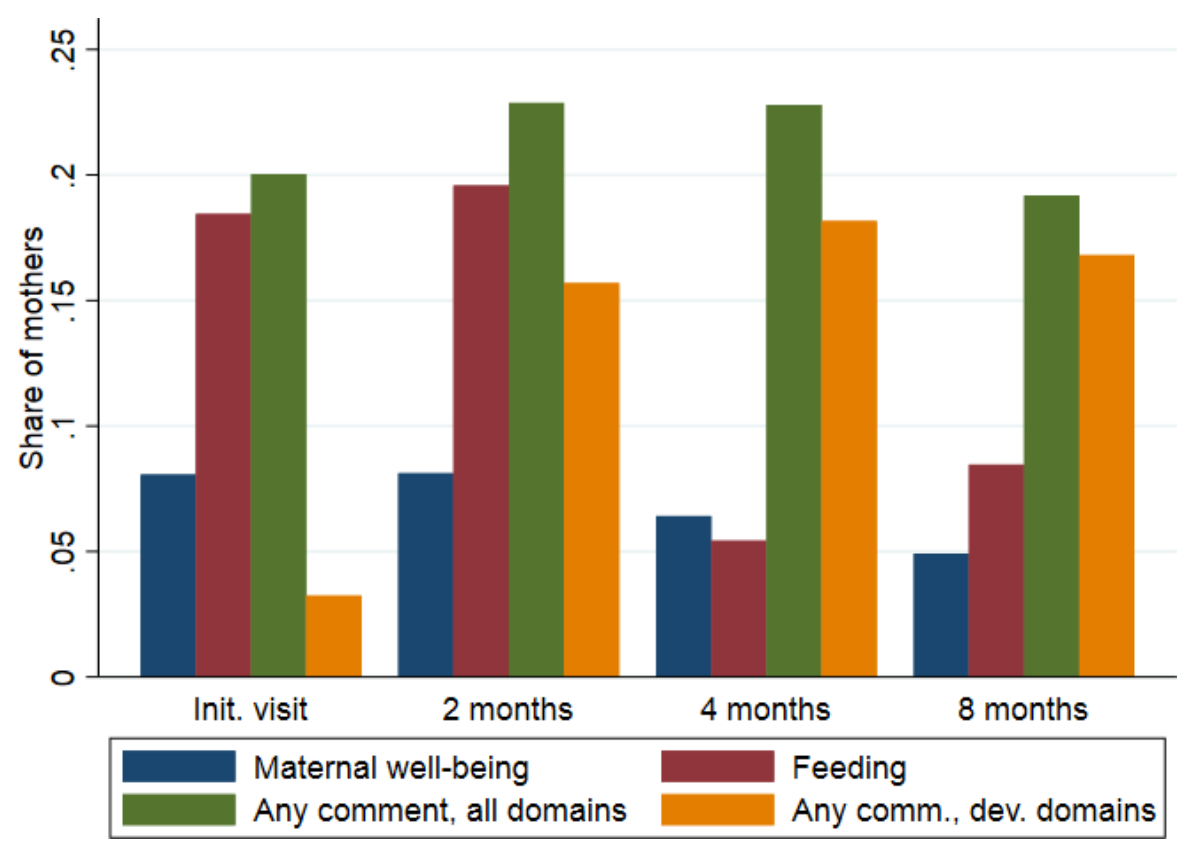

Fig. 1 Share of mothers/children with nurse registrations of issues at a given nurse visit (initial visit through eight months visit)

Notes: The share of children with registered issues in each domain for all children with a performed visit and born between September 17, 2008 - April 15, 2009 (the control period). Each domain aggregates a set of binary measures. Children's issue indicator is one if at least one binary measure is registered as problematic by the family's nurse.

\subsection{Data and Variable Construction}

In our analysis, we use data from two sources. First, we access archived records on the universe of home visits from the municipality of Copenhagen for the 2007-2009 period. ${ }^{12}$ These registrations were either completed at the family home (using a laptop) or at the nurse's office directly after a completed visit. For each visit, the data contain the date and type of visit. Additionally, nurses register their observations regarding factors such as child and maternal health, feeding problems, or relevant risk factors in the family (see Table 1 for

\footnotetext{
${ }^{12}$ These data come from an archive version of the municipality's administrative system. The full archive of nurse records from Copenhagen includes data on all visits and examinations of children resident in the municipality from January 1, 2007 to December 31, 2010-a total of 35,213 children. These records were transferred to the Copenhagen city archive due to a change of the software used by the Copenhagen nurses. As we are interested in studying the impact of timing of nurse visits in the first year of the child's life, we do not consider data from the 2010 cohort as they are right-censored, i.e. we do not observe information on all visits before the end of the data period.
} 
examples of focus areas and registration options at different visits).

Second, using children'suniquesocial security number, wemergethenurserecords with population administrative data from Statistics Denmark for the birth cohorts 2007-2010. ${ }^{13}$ The administrative data contains a large set of parental background characteristics such as educational attainment, income, age, civil status and family links irrespective of co-residence, and municipality of residenceand birthrecords. Moreover, theadministrativebirth records provide information on measures such as children's birth weight and length, gestation age, the five minuteAPGAR-score, hospital of birth identifiers and take-up and number of prenatal midwife contacts.

Usingdatafortheyears 2007-2014, wecreatethreesets of health outcomemeasuresfrom the administrative data: First, to study child and maternal health, we examine both the yearly and accumulated number of GP contacts from child age zero to four. GP contacts include both physical meetings and phone and e-mail correspondence with a GP. ${ }^{14}$ Given that we only measure health care usage in our data, weare concerned as to whether we pick up actual impacts of strike exposure on child health: Parents may behave more cautious and-in the short run-substitute nurse care with GP care. In the longer run, parents may continue to demand more care, for example, because they build a strong relationship with their family GP due to increased initial contacts.

While we cannot fully disentangle true health effects from alternative explanations for changesin health caretake-up, weattempt to providemoreinsights bydividing ourmeasure of GP contacts into two categories: i) regular (scheduled) GP contacts that typically involve the family GP, and ii) emergency GP contacts (i.e., GP contacts on weekends or outside default opening hours, which are not performed by the family GP). ${ }^{15}$ While not perfectly

\footnotetext{
${ }^{13}$ In our reduced form analysis of strike exposure on child outcomes, we use an additional cohort of children (2010) in our control group. Our results are not sensitive to the choice of control years, as detailed in section 4.5.

${ }^{\text {I }} \mathrm{GPs}$ offers regular phone consultation hours (typically in the early morning).

${ }^{15}$ Emergency GP care was restructured in 2015 and thus there is a data break in the administrative data. Therefore, in our main analysis, we focus on GP contacts in the first four years of life where both treated and control children are exposed to the same regime of emergency GP care. Analyses that also include 2015 and later years (and only consider non-emergency GP care) lead to very similar results that are available on
} 
independent, emergency GP contacts may be a more direct measure of poor health that requires attention. Importantly, we do not include child GP contacts in the preventive care program in our main outcome measure, but analyze those contacts separately. Thus our measures of GP contacts (scheduled contacts and emergency contacts) do not measure the participation in the voluntary preventive care program but focus on contacts due to health problems or parental concerns about the child's health. Moreover, our follow-up period of up to four years (and our analyses of GP contacts after the initial year of the child's life) allows us to speak to the role of substitution between nurse visits and GP contacts: While first-year effects on GP contacts may be caused by substitution, the scope for substitution in the longer-run is likely small.

As alternative measures of child health, wealso consider two types of hospital contacts: Hospital admissions and outpatient contacts. Around 25 and 39 percent of children are admitted to the hospital or have an outpatient contact during their first year of life, respectively. While contacts to hospitals may capture more extreme health problems, these figures illustrate that, in general, hospital contacts are not rare and often related to routine check-ups. Oneaspect worth notingis that the 2008 strikecovered all unionized nurses and thushospital carefornon-emergency patients was restricted. Therefore, GPs may havebeen more reluctant in referring children to hospitals in the strike period.

Second, weconsidertheimpactof strikeexposureon maternal postpartummental health problems. Thesepotential effectsareinterestingin theirownrightandalso asmechanismsor reinforcing factors for longer-run effects of strike exposure on children. We create an indicator that is equal to one if mothers have any contact with a psychologist and/ or psychiatrist in the first two years after the child's birth. We also consider the more extreme margin of maternal outpatient and inpatient contacts with psychiatric specialists up to twoyears after the child's birth. ${ }^{16}$

${ }^{16}$ We include diagnoses (using the International Statistical Classification of Diseases and Related Health Problems (ICD) system) between F01-F99.
} 
Third, we study the impact of strike exposure on parental health investmentdecisions. As we exploit information on a sample of children exposed to the nurse strike (and thus the absence of nurse visits at specific ages), we are constrained in our ability to use nurse registrations on parental inputs as outcome measures in our main analyses. ${ }^{17}$ Relyingon administrative data instead, we consider indicators for participation in the GP preventive careprogram, participation in thevaccination program, and thetimelycompletion of rounds in thevaccination program. As the nurse visits are closely spaced around the recommended ageforthefirstyearvaccinations, weassess whethermissingaspecificnursevisitimpactsthe probability of atimelyvaccination, which wetakeasaproxy forparental healthinvestments.

\section{Empirical Methods}

ToexaminetheeffectsofthetimingofNHV, weexploitchildren'sexposuretothenursestrike in a difference-in-differences framework. Specifically, we estimate the following reduced form relationship:

$$
\begin{aligned}
y_{\mathrm{it}}= & a_{0}+{ }_{\mathrm{j}=-7}^{-1} \varphi_{\mathrm{j}} 1\left(\text { bin30 }_{\mathrm{it}}=j\right) \times 1\left(\text { Year }_{\mathrm{t}}=2008\right) \\
& +{ }_{\mathrm{j}=-7}^{-1} \beta_{\mathrm{j}} 1\left(\text { bin30 }_{\mathrm{it}}=j\right)+{ }_{\gamma} \boldsymbol{X}_{\mathrm{it}}+\lambda_{\mathrm{t}}+E_{\mathrm{it}}
\end{aligned}
$$

where $y_{i t}$ is an outcome measure, such as GP contacts in the first year of life for child $i$ born at time $t$. In our analyses for outcome measures from the administrative data, we considerall children born in the210 dayperiod prior to April 15in theyears 2008, 2009 and 2010 (12,078 children).$^{18}$ Wesplit each period in seven 30-days bins and includeindicators

\footnotetext{
${ }^{17}$ In supplementary analyses, we have constrained our sample to early strike-exposed children and study their outcomes at the nurse visit around eight months (D visit). We have considered indicators for nurseobserved issues concerning mother well-being, feeding, child-parent contact as well as indicators for any nurse comments at all and referrals by nurses. However, these analyses rely on a very small sample relative to the expected effect sizes (and the expected noise in the measurement of outcomes by nurses) and is thus not very informative. Unfortunately, the nurse data on infant feeding (duration of breastfeeding) in the archived data are of very poor quality and we cannot use them at all.

${ }^{18}$ As mothers given birth during the strike also had a larger probability of being discharged on the day
} 
that are equal to one if child i's date of birth is within a particular bin. Weinclude a set of fixed effects for therelevant cohort, $\lambda .{ }^{19}$ Theinteractions of the period bins with an indicator for the 2008 cohort (theyear of the strike) identify our estimates of interest: Children born prior tothestrikein 2008 aretreated whilechildren born at thesamedatesin 2009 and 2010 are untreated. We omit the bin furthest from April 15 and children in this group constitute the referencegroup.

In our main specification, we include the following covariates $\left(X_{\mathrm{it}}\right)$ : paternal and maternal total income, indicators for the highest level of education (primary school, higher education, university degree), indicators for currently studying and for being employed, an indicator for parental civil status (cohabiting, married) and indicators for missing covariates. All the $X_{\text {it }}$ are measured one year prior to birth of the focal child. Additionally, we control for measures drawn from the birth records, including the number of prenatal midwifevisits and indicators for parents being below21years old, indicators for having had a Caesarean section or a home birth, and indicators for the child having been low birth weight (below 2500g), a preterm birth (below 37 weeks), child gender and maternal smoking status at birth.

The coefficients from interacting the age bins and the strike period indicator provide intention-to-treat(ITT) estimates of strikeexposureata certain agerelativeto thereference group. To show that strike exposure is relevant, we present estimates for theimpact of strike exposure on the probability of missing a nurse visit at a specific time in the child's life (the first stage). Furthermore, we present evidence on complier characteristics that substantiates our assessment of thestrikeasabroad treatmentimpactingfamiliesacrossmanyobservable dimensions.

of birth and fewer midwife visits (Kronborg et al., 2016), including children born during the strike would confound the impact of NHV with the impact of other aspects of care.

${ }^{19}$ Note that the year indicators cross calendar years: As an example the indicator for the year 2008 (the treated year) is equal to one for all birth in the 210 days prior to April 15, 2008 and thus identifies births in the calendar years 2007/2008. 


\subsection{Identifying assumptions}

For our estimates to identify the causal impact of exposure to the nurse strike, we make two identifyingassumptions. First, weassumethat, in theabsenceof thestrike, thedifference-indifferences between children born in specific periods up to April 15 in the strikeand control years should bezero (common trend). Thus our frameworkallows for theyears 2008, 2009 and 2010 to differ in levels. These differences could, for example, be due to overall trends in children's health or macroeconomic shocks that affect care and health of children. Our focus on births from different months of the year also calls for a discussion of the impact of seasonality: Weallow children born across seasons to be systematically different from each other (with respect to their average outcomes) as long as this seasonality is the same across all cohorts.

One way of empirically assessing the untestable common trend assumption is tostudy predetermined variables, which should beunrelated to treatment exposure. In other words, we estimate model (1) using parental and birth characteristics as dependent variables. Our treated and control groups are balanced across observable pre-treatment characteristics (Appendix TablesA2 and A3). Wefind very fewdifferencesacross thegroupsand only at modest levels of significance. ${ }^{20}$ Another informal test is the assessment of pre-trends in outcomes across groups. As we do not observe children's GP visits prior to treatment, we consider maternal pre-birth outcomes: Appendix FigureA2 plots pre-birth averages of maternal GP contacts and mothers receivingmedical contacts with a psychiatric diagnosis for thetreated and control children (born in the 210 day period up to the strike in treated and control years) ${ }^{21}$ The figure shows similar trends and levels for both measures of maternal health prior to birth.

Second, weassume that there are no other policies or shocks that covary with thetiming of the strike. To provide support for this assumption, we assess whether strike exposure

\footnotetext{
${ }^{20}$ We have also tested the joint significance of the interaction between the age bins and the strike indicator in each of these regressions. None of the joint tests are significant at the 10 percent-level. Results are available on request.

${ }^{21}$ We include hospital contact diagnoses (using the ICD system) between F00-F99.
} 
is related to differential health care provision through other channels than NHV. Similarly to Appendix Figure A2, Appendix Figure A3 plots the average number of prenatal midwife visits and GP consultations, theaveragenumber of days admitted to hospital after birth, and the share of mothers having a C-section for mothers in the strike-exposed year and control years. The graphs do not indicate systematic differences or trends in any of these types of care around birth across the groups that we consider.

A final concerns that we address is individuals' selection out of the strike treatment or out of our sample. First, families could not to manipulate their treatment status since all children in our analysis sample were born either prior to the strike or a minimum of four month after the strike ended. ${ }^{22}$ Second, families could select out of our analysis sample by moving to a different municipality or out of the country. In our main analysis, to focus on children who were either treated with default care in Copenhagen or by the strike while residing in Copenhagen, we omit data for 1,962 children who move out of the municipality duringtheirfirstyearoflife. Ifstrikeexposed familiesaremore(orless) inclined to move, our estimates could be biased. ${ }^{23}$ Appendix Figure A5 shows that this concern is not important as the share of children that we observe as Copenhagen residents during their first year of life is not impacted for treated and control cohorts. However, as a robustness check, we include domestic movers into our main analyses (so that only death and migration abroad cause exclusion). ${ }^{24}$

\footnotetext{
${ }^{22}$ In Appendix Figure A4 we show that the density of births around the strike does not indicate bunching around the beginning or end of the strike period.

${ }^{23}$ As the strike was a nation-wide strike and of relative short duration (which parents were aware of), the risk of strike-induced domestic migration should be small.

${ }^{24}$ We know individuals municipality of residence at January 1 each year. We restrict children born 210 days prior to April 15, 2008, 2009 and 2010 to still reside in Copenhagen at January 1, 2009, 2010, 2011 respectively.
} 


\section{Results}

\subsection{Descriptive Statistics}

Table 2 presents summary statistics for our main sample of children born in Copenhagen acrossthegroupsoftreated children (born September 18, 2007-April 14, 2008) and children in the control group (born September 17, 2008 (2009) - April 14, 2009 (2010)). In the top panel, we present summary statistics for outcomes and covariates from the administrative data. In the bottom panel, we present variables on nurse visits from the nurse records from Copenhagen. In this panel, wefurther constrain our sample to the data periods in theyears 2008 and 2009 as the nurse data is right-censored for the children born in 2010.

Control children have on average 4.6 and $10.4 \mathrm{GP}$ contacts during the first and second year of life respectively. During the third and fourth year of life children have 10.2 contacts. RegularGP contacts constitutearound two thirds of thetotal number of contacts. Theinfant vaccinationsand preventivehealthcheckshavehigh coverageratesataround 90 percent. The treated and control groups are well-balanced across covariates.

Focusing on the bottom panel of Table 2, we find that the four universal nurse visits are well attended. The average number of universal visits per child is 3.3 for controlchildren. This figure implies that the average child receives three out of the four universal visits. On average, children additionally receive one home visit scheduled due to a specific need. This average masks heterogeneity across children. 
Table 2 Variable means, strike exposed and control period

\begin{tabular}{|c|c|c|c|c|}
\hline & \multicolumn{2}{|c|}{ Treated group } & \multicolumn{2}{|c|}{ Control group } \\
\hline & Mean & Obs. & Mean & Obs. \\
\hline Total GP 1st year & 4.44 & 4081 & 4.55 & 8725 \\
\hline Total GP 2nd year & 10.69 & 4049 & 10.35 & 8649 \\
\hline Total GP 3-4 years & 11.10 & 3955 & 10.22 & 8451 \\
\hline Emerg. GP 1st year & 1.42 & 4081 & 1.47 & 8725 \\
\hline Emerg. GP 2nd year & 3.75 & 4049 & 3.46 & 8649 \\
\hline Emerg. GP 3-4 years & 3.50 & 3955 & 3.18 & 8451 \\
\hline Vacc., 1st round & 0.85 & 4081 & 0.90 & 8725 \\
\hline Vacc., 2nd round & 0.87 & 4081 & 0.91 & 8725 \\
\hline Vacc., 3rd round & 0.88 & 4081 & 0.91 & 8725 \\
\hline Prev. care, 5 weeks & 0.88 & 4081 & 0.92 & 8725 \\
\hline Prev. care, 5 months & 0.92 & 4081 & 0.93 & 8725 \\
\hline Prev. care, 12 months & 0.93 & 4081 & 0.93 & 8725 \\
\hline Emerg. GP 1st year mothers & 0.72 & 4081 & 0.70 & 8725 \\
\hline Emerg. GP 2-4 years mothers & 2.10 & 3950 & 1.97 & 8445 \\
\hline Mother psych. diag. 1st year & 0.01 & 4081 & 0.01 & 8725 \\
\hline Mother psych. hosp. adm. 3 years & 0.01 & 4081 & 0.01 & 8725 \\
\hline Mother psych. outpat. cont. 3 years & 0.03 & 4081 & 0.03 & 8725 \\
\hline Midwife visits & 4.80 & 3970 & 4.75 & 8507 \\
\hline Smoking status, Mother & 0.10 & 4014 & 0.09 & 8587 \\
\hline Child sex & 0.48 & 4081 & 0.48 & 8725 \\
\hline Low birth weight & 0.04 & 4009 & 0.06 & 8598 \\
\hline Preterm birth & 0.06 & 4014 & 0.06 & 8587 \\
\hline C-section & 0.21 & 4081 & 0.21 & 8725 \\
\hline Home birth & 0.01 & 4081 & 0.01 & 8725 \\
\hline Cohabiting & 0.76 & 4081 & 0.78 & 8725 \\
\hline Married & 0.37 & 4081 & 0.39 & 8725 \\
\hline Prim. school, mother & 0.15 & 4081 & 0.12 & 8725 \\
\hline Uni. degree, mother & 0.30 & 4081 & 0.32 & 8725 \\
\hline Student, mother & 0.05 & 4081 & 0.05 & 8725 \\
\hline Employed, mother & 0.77 & 4081 & 0.77 & 8725 \\
\hline Danish, mother & 0.76 & 4081 & 0.74 & 8725 \\
\hline Young mother & 0.02 & 4081 & 0.02 & 8725 \\
\hline Young father & 0.01 & 4014 & 0.01 & 8551 \\
\hline Income, mother & 281.78 & 4081 & 289.58 & 8725 \\
\hline No. of nurse visits & 3.77 & 4081 & 4.40 & 4269 \\
\hline Number of registered A-D visits & 2.70 & 4081 & 3.28 & 4269 \\
\hline No initial visit & 0.16 & 4081 & 0.08 & 4269 \\
\hline No 2-month visit & 0.44 & 4081 & 0.25 & 4269 \\
\hline No 4-month visit & 0.44 & 4081 & 0.24 & 4269 \\
\hline No 8-month visit & 0.26 & 4081 & 0.15 & 4269 \\
\hline
\end{tabular}


Table 2 also illustrates the impact of strike exposure on the program coverage: For all types of visits, treated children have a higher probability of missing the given visit. The differencein thenumber of universal visitsacross groupsisidentical tothedifferencein their total number of visits. This finding indicates that the average number of extra visits was not affected dramatically by the strike. In the following, we will in analyze these patterns greater details. ${ }^{25}$

\subsection{First Stage and Compliers}

In Denmark, both private and public wages are to a large degree determined by collective bargaining (Ibsen et al., 2011). In 2008, the negotiations for all publicly-employed nurses, midwives and alarge fraction of other employees in the publichealth sector brokedown and resulted in a conflict. Thus on April 15, 2008 the unionized employees in the health care sector went on a national strike. As a result, a total of 45 percent of publicemployees wereon strikein the following weeks (Dueand Madsen, 2008). The strikelasted 61 days and ended on J une 14, 2008. ${ }^{26}$ During the strike period, only managing nurses and a small fraction of regular nurses (employed on specificterms and thus not participating in the strike) wereon duty in Copenhagen, the setting for our analysis. Thesenurses carried out around onetenth of theexpectablenon-strikedefaultof nursevisits. ${ }^{27}$ Moreover, theyprovided phoneservices for families that were affected by the strike.

\footnotetext{
${ }^{25}$ To assess the representativeness of our sample of families from the capital of Denmark, Appendix Table A4 compares children and parents from Copenhagen to the general Danish population of parents. Children and parents from Copenhagen differ from the general population on a number of characteristics: they are more likely to cohabit and less likely to be married. Mothers from Copenhagen have a higher educational attainment. Parents from Copenhagen are less likely to be employed and of Danish origin. With respect to children's health and characteristics, children in Copenhagen resemble children from the rest of county: 5 percent of children are low birth weight children and 7 percent are born prematurely. Children in Copenhagen are also similar to the rest of Denmark with respect to the number of nights at hospital after birth, the number of prenatal midwife visits, the rate of C-section deliveries, and the share of home births. At the same time, 62 percent of children born in Copenhagen are firstborns compared to 43 percent outside Copenhagen, their parents are older and less likely to smoke.

${ }^{26}$ The unions demanded a 15 percent wage growth. The agreement resulted in a 13.3 percent wage increase over a three-year duration.

${ }^{27}$ We calculate this share of performed visits by comparing the strike period to the same period in the following year.
} 
Appendix FigureA1 presents graphically theimpact of strikeexposure on thenumber of nurse visits for children in the treated and control cohorts in Copenhagen (2007/ 2008 and $2008 / 2009$, respectively). Strike exposure impacted the total number of nurse visits that children received. Panel (a) of Appendix Figure A1 shows that control children receive an average of 3.3 visits while treated children receive 2.7. Panel (b) shows the total number of visits (universal + extra) divided by treatment status. Theyoungest strike exposed children appear to not only loose one but two nurse visits. This finding reflects that early hospitaldischarged children receive two visits within the first 14 days of life- one universal visit and one extra visit. In section 4.5, we examine the robustness of our general conclusions to the omission of this group of children (a doughnut hole-approach).

Tofurther examinetheimpact of thestrikeon nursevisitsand toillustratetheidentifying variation that we use (i.e., the overall decrease of the number of visits is driven by a lack of visits at specific ages), Figure 2 shows the impact of strike exposure on the probability of missing a specific nurse visit. The figure shows the raw relationship between date of birth and missing a nursevisit estimated with kernel weighted local polynomials. Weusean epanechnikov kernel, arule-of-thump bandwidth and 42 (5-day) smoothingpoints through out. Blacklinesand confidenceintervalsarefor thetreated period, greylinesand confidence intervals are for the control periods. ${ }^{28}$ The graphs plot the probability of missing a nurse visit for children born in the 210 days before the strike for the years 2008 and 2009.

In absence of strike, the share of children, who miss a specific nurse visit, is stable as indicated by the grey lines in Figure 2. 60 percent of children born immediately before the strike miss theinitial visit whileall children older than approximately 20 days at strikestart miss the initial visit with unaffected probability (20 percent). Panels (b) and (c) show that missing the two and four month visits is also correlated with child ageat strike. Finally, only the oldest children in our sample have an increased probability of missing the eight month visit while all theyounger children are unaffected at that time (because the strike ended by

\footnotetext{
${ }^{\mathbf{2 8}}$ We construct graphs that plot outcomes similarly unless otherwise noted.
} 
the time their visit was due).

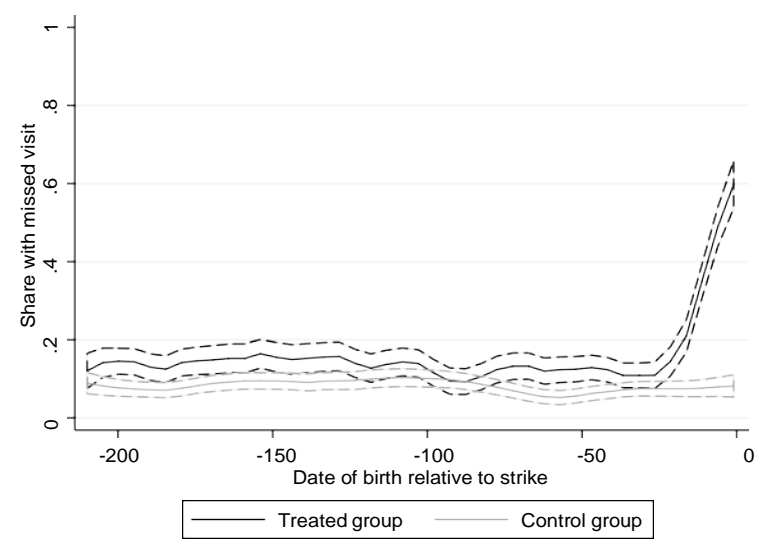

(a) Missed initial visit

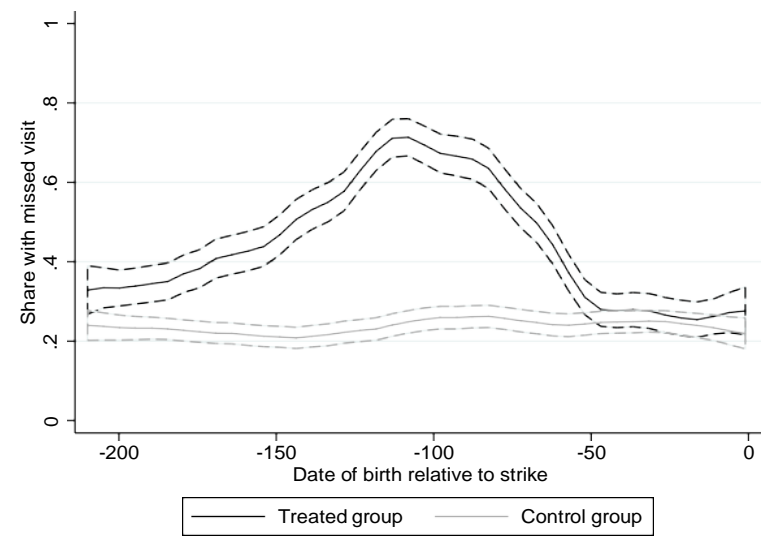

(c) Missed four months visit

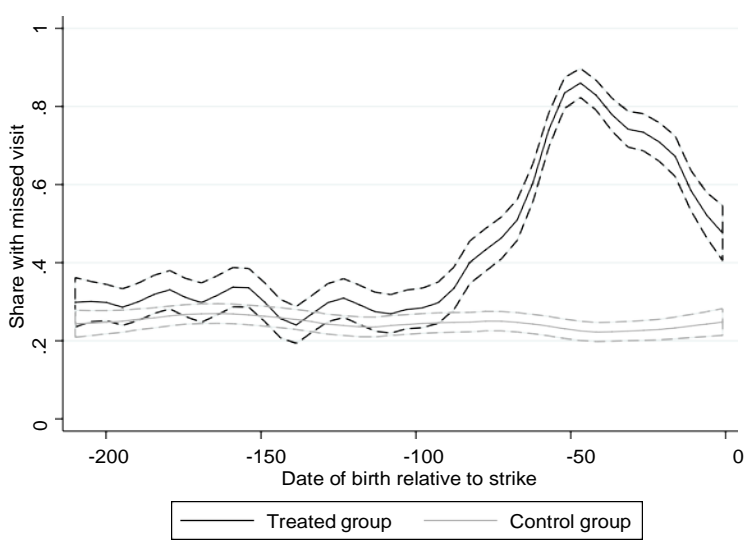

(b) Missed two months visit

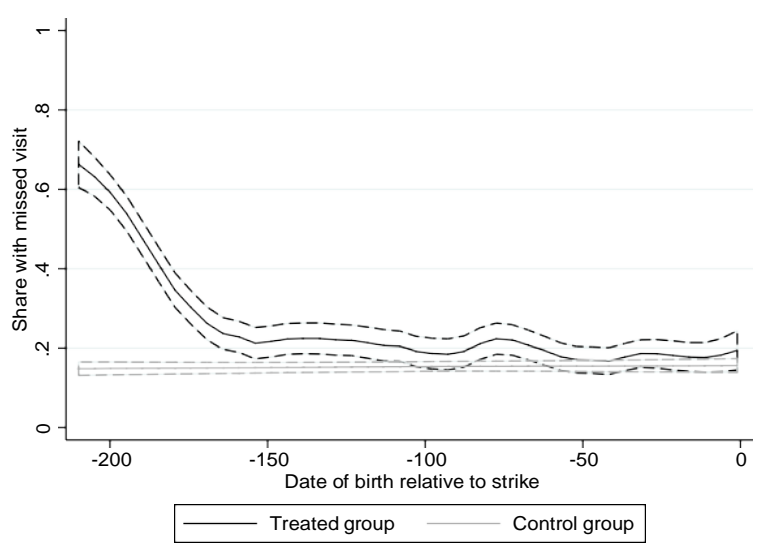

(d) Missed eight months visit

Fig. 2 Share of children with missed nurse visits for children born in the treated and control period Notes: The figure shows the raw relationship between date of birth and missing a nurse visit estimated with kernel weighted local polynomials using an epanechnikov kernel, a rule-of-thump bandwidth and 42 (5-day) smoothing points. The black line and dashed black confidence intervals are for the treated period, the grey line and dashed grey confidence intervals are for the control period. Treated period: September 18, 2007 April 15, 2008. Control period: September 17, 2008 - April 15, 2009).

Table 3 presents formal estimates from regressions based on Equation (1). Coefficients reflect the effect of being born in a specific bin on the probability of not receiving each nurse visit (the omitted baseline is the 30 days bin furthest from strike start). The columns show results for the different types of universal nurse visits. The regression results mirror the graphical representation: The strike only has an impact on theinitial visit for children who 
were between 30-0 days at strike start. On average children in this bin have 17.1 percentpointshigherprobability ofmissingtheinitial visit(relativetothereferencegroup). Children who were 90 days and below at strike start have an increased probability of a missed two month visit with the 60-31 bin most severely affected (51.1 percent-points). Children who were between 61 and 150 days at strike start have their four month visit most severely affected by the strike. Only the oldest children in the strike exposed period haveincreased probability of a missed eight month visit compared toyounger children (around 40 percentpoints difference when compared to the children, who were youngest at strike start). As shown in column (5) strike exposure does not differentially impact children's number of completed universal visits. However, children in the 30-1 day bin loose on average 0.267 nurse visits more than the reference group (significant at the 10 percent level). This result reflects that children below age two weeks at strike start potentially loose two visits, theuniversal initial visit and an additional early visit if discharged shortly after birth.

Having established that age at strike start has a meaningful impact on timing of the missed nursevisit for strike-exposed children, we havethe concern that nurses strategically chosethechildren they visited, i.e. that only the most well-off children wereimpacted by the child. This question is important for theinterpretation of our findings. In general, thelarge scale of the strike-with only one tenth of performed nurse visits in Copenhagen during the strikerelativeto thedefault-suggests that thestrikeimpactedlarge parts of thepopulation. However, our unique data also allows us to characterize compliers (i.e. children who missed nurse visits due to the strike) more formally in our sample.

Table 4 characterizes the compliers with respect to the probability of missing the first nurse visit (analyses for the other three universal visits lead to similar conclusions and are available on request). Following Angrist and Pischke(2008), we characterize the compliers byi) splitting thefull sample into relevant subgroups, ii) estimating the model for each subgroupindividuallyand iii) calculating theratio between thecoefficientsfrom each subgroup and thefull population. Theratios are therelativelikelihood that a complier belongs to that 
Table 3 First stage: Effects of strike exposure on the probability of a missed nurse visit

\begin{tabular}{|c|c|c|c|c|c|c|}
\hline & $\begin{array}{c}\text { (1) } \\
\text { No initial } \\
\text { visit }\end{array}$ & $\begin{array}{c}\text { (2) } \\
\text { No 2-months } \\
\text { visit }\end{array}$ & $\begin{array}{c}\text { (3) } \\
\text { No 4-months } \\
\text { visit } \\
\end{array}$ & $\begin{array}{c}\text { (4) } \\
\text { No 8-months } \\
\text { visit }\end{array}$ & $\begin{array}{c}\text { (5) } \\
\text { Number of registered } \\
\text { A-D visits }\end{array}$ & $\begin{array}{c}\text { (6) } \\
\text { No. of } \\
\text { nurse visits }\end{array}$ \\
\hline \multicolumn{7}{|c|}{ C } \\
\hline 180-151 & $\begin{array}{r}0.002 \\
(0.026)\end{array}$ & $\begin{array}{c}-0.040 \\
(0.037)\end{array}$ & $\begin{array}{c}0.100^{* * *} \\
(0.037)\end{array}$ & $\begin{array}{c}-0.324^{* * *} \\
(0.034)\end{array}$ & $\begin{array}{c}0.261^{* * *} \\
(0.091)\end{array}$ & $\begin{array}{c}0.223 \\
(0.166)\end{array}$ \\
\hline $150-121$ & $\begin{array}{r}0.003 \\
(0.026)\end{array}$ & $\begin{array}{c}-0.018 \\
(0.037)\end{array}$ & $\begin{array}{c}0.247^{* * *} \\
(0.037)\end{array}$ & $\begin{array}{c}-0.357^{* * *} \\
(0.034)\end{array}$ & $\begin{array}{c}0.126 \\
(0.090)\end{array}$ & $\begin{array}{c}0.205 \\
(0.162)\end{array}$ \\
\hline 120-91 & $\begin{array}{l}-0.027 \\
(0.026)\end{array}$ & $\begin{array}{c}-0.017 \\
(0.037)\end{array}$ & $\begin{array}{c}0.364^{* * *} \\
(0.037)\end{array}$ & $\begin{array}{c}-0.363^{* * *} \\
(0.033)\end{array}$ & $\begin{array}{c}0.043 \\
(0.088)\end{array}$ & $\begin{array}{c}0.181 \\
(0.164)\end{array}$ \\
\hline $90-61$ & $\begin{array}{l}-0.007 \\
(0.025)\end{array}$ & $\begin{array}{c}0.155^{* * *} \\
(0.038)\end{array}$ & $\begin{array}{c}0.225^{* * *} \\
(0.038)\end{array}$ & $\begin{array}{c}-0.353^{* * *} \\
(0.034)\end{array}$ & $\begin{array}{c}-0.020 \\
(0.087)\end{array}$ & $\begin{array}{c}0.247 \\
(0.163)\end{array}$ \\
\hline $60-31$ & $\begin{array}{l}-0.005 \\
(0.024)\end{array}$ & $\begin{array}{c}0.511^{* * *} \\
(0.035)\end{array}$ & $\begin{array}{c}-0.039 \\
(0.036)\end{array}$ & $\begin{array}{c}-0.423^{* * *} \\
(0.033)\end{array}$ & $\begin{array}{c}-0.044 \\
(0.083)\end{array}$ & $\begin{array}{c}0.115 \\
(0.153)\end{array}$ \\
\hline 30-1 & $\begin{array}{c}0.171^{* * *} \\
(0.028)\end{array}$ & $\begin{array}{c}0.323^{* * *} \\
(0.037)\end{array}$ & $\begin{array}{c}-0.079 * * \\
(0.036)\end{array}$ & $\begin{array}{c}-0.395^{* * *} \\
(0.033)\end{array}$ & $\begin{array}{c}-0.019 \\
(0.085)\end{array}$ & $\begin{array}{c}-0.267^{*} \\
(0.158)\end{array}$ \\
\hline Obs. & 7874 & 7874 & 7874 & 7874 & 7874 & 7874 \\
\hline \multicolumn{7}{|c|}{$\begin{array}{l}\text { Notes: Each column shows estimates from separate regressions. The coefficients are for the interactions of 30-day bins and a strike year indicator. All } \\
\text { regressions include period and bin fixed effects, as well as control variables. Parental covariates are paternal and maternal income, indicators for the } \\
\text { highest level of parental education (primary school, high school, university degree), indicators for the mother currently studying or being employed, } \\
\text { parental cohabitation and marital status and separate indicators for missing covariates. All covariates are measured one year prior to birth of the } \\
\text { focal child. Child/birth covariates include indicators for parental age below } 21 \text { at birth, indicators for a C-section, home birth, low birth weight (below } \\
2500 \mathrm{~g} \text { ), a preterm birth (below } 37 \text { weeks), child gender, maternal smoking status at birth and the number of prenatal midwife visits. The sample } \\
\text { includes children born in Copenhagen in the treated period (September } 18,2007 \text { - April } 15,2008 \text { ) and in control period (September } 17,2008-\text { April } \\
15,2009 \text { ). The outcomes in columns (1)-(4) are indicators for the probability of having missed the respective universal home visit. The outcome in } \\
\text { column (5) is the number of universal nurse visits received. Column }(6) \text { presents results for the total number of nurse visits (universal and additional } \\
\text { visits). Robust standard errors in parentheses. }{ }^{* * *}<0.01,{ }^{* * p}<0.05 \text { and }{ }^{*} p<0.10 \text {. }\end{array}$} \\
\hline
\end{tabular}


particular subgroup. Welook at the first stage estimates across groups of families defined by characteristics that may at least be partly observed by the nurses: child gender, parental education in a health-related field, ${ }^{29}$ initial child health, ${ }^{30}$ and child parity. ,We show coefficients for the 30-day bin as only children born in that bin were affected by the strike. In general, the complier analysis suggests that the strike affected the considered subgroups relatively similarly and a stronger first stage does not covary with characteristics that may indicate positive potential outcomes. Thus we think it is reasonable to state that nurses did not prioritize to a great degree based on thegiven characteristics. Thisfinding is relevantfor our interpretation of especially heterogeneous effects (because we can rule out that nurses' prioritized certain subgroups during the strike as a main driving factor).

Taken together, strike-exposed children missed on average one nurse visit. Thus we cannot fully disentangle the effect of having one less nurse visit from the effects of timing. Strike exposed children missed this visit at different ages and we compare outcomes of children across yearsrelativetothereferencegroup of children born 180-210 dayspriortothestrike. Ourfirst stage results providepowerful evidencefor the differential timing of theassigned treatment (one less visit). Thus we think it is reasonable to interpret our findings as predominantly being driven by timing given that the different visits coverage-specific topics, as outlined in section 2.

\subsection{Main Results: Child and Maternal Health}

Tomeasuretheimpact of strike exposureat differentages on children's and mother's health, we use outcomes from the administrative data. Figure 3 presents graphical evidence of the raw relationship between age at strike start and accumulated GP contacts at ages one through four. ${ }^{31}$ The number of accumulated GP contacts reveal a clear pattern: Children,

\footnotetext{
${ }^{29}$ Having parents with an educational background in a (child) health-related field implies that either one of the parents are educated as doctor, midwife, nurse or pedagogue.

${ }^{30} \mathrm{We}$ define a children with low initial health as having a birth weight below $2500 \mathrm{~g}$ and/or being born preterm.

3'Figures for regular and emergency contacts are available on request.
} 
Table 4 Compliers: Effects of strike exposure on the probability of missing the initial visit by subgroup

\begin{tabular}{|c|c|c|c|c|c|c|c|c|}
\hline & \multicolumn{2}{|c|}{ Gender } & \multicolumn{2}{|c|}{ Education } & \multicolumn{2}{|c|}{ Initial health } & \multicolumn{2}{|c|}{ Parity } \\
\hline & $\begin{array}{l}\text { Boys } \\
\text { (1) }\end{array}$ & $\begin{array}{c}\text { Girls } \\
\text { (2) }\end{array}$ & $\begin{array}{c}\text { Not health } \\
\text { (3) }\end{array}$ & $\begin{array}{l}\text { Health } \\
\text { (4) }\end{array}$ & $\begin{array}{l}\text { Not poor } \\
\text { (5) }\end{array}$ & $\begin{array}{c}\text { Poor } \\
(6)\end{array}$ & $\begin{array}{l}>1 \\
(7)\end{array}$ & $\begin{array}{l}=1 \\
(8)\end{array}$ \\
\hline \multicolumn{9}{|l|}{ Days } \\
\hline 30-1 & $\begin{array}{c}0.199 * * * \\
(0.040)\end{array}$ & $\begin{array}{l}0.130^{* * *} \\
(0.039)\end{array}$ & $\begin{array}{c}0.151^{* * *} \\
(0.032)\end{array}$ & $\begin{array}{c}0.217^{* * *} \\
(0.059)\end{array}$ & $\begin{array}{c}0.157^{* * *} \\
(0.029)\end{array}$ & $\begin{array}{c}0.237^{* *} \\
(0.117)\end{array}$ & $\begin{array}{l}0.132^{* * *} \\
(0.046)\end{array}$ & $\begin{array}{l}0.194^{* * *} \\
(0.035)\end{array}$ \\
\hline Ratio to full pop. & 1.19 & 0.78 & 0.90 & 1.29 & 0.94 & 1.41 & 0.78 & 1.15 \\
\hline Control group mean & 0.09 & 0.07 & 0.08 & 0.09 & 0.08 & 0.11 & 0.10 & 0.07 \\
\hline Observations & 4101 & 3773 & 6156 & 1718 & 7276 & 598 & 3026 & 4848 \\
\hline
\end{tabular}

Notes: See notes for Table 3. In this table, we present estimates for the interactions of 30-day bins and a strike indicator from separate regressions for various subgroups along with the ratio between the full-sample estimates and the various subgroup-estimates (both sets of regressions excluding control variables). We only show the estimates for the 30-1 day bin because only children in this bin had their initial visit affected by the strike in the full population. Robust standard errors in parentheses. ${ }^{* *} p<0.01,{ }^{* *} p<0.05$ and ${ }^{*} p<0.10$. 
who were youngest at strike start in 2008 have significantly more GP contacts relative to children of older age groups and this pattern looks different in the control group. As Figure 3 further illustrates, there is a gradient inside the early strike-exposed group of children such that the youngest children have most GP contacts. This finding indicates that earlier $\mathrm{NHV}$ is relatively more important for child health than later NHV. For children older than 100 days at strike start, the average number of GP contacts is similar to the average for control children. Interestingly, theimpact of missing an early nurse visit is persistent as the differences increase as the children ages.

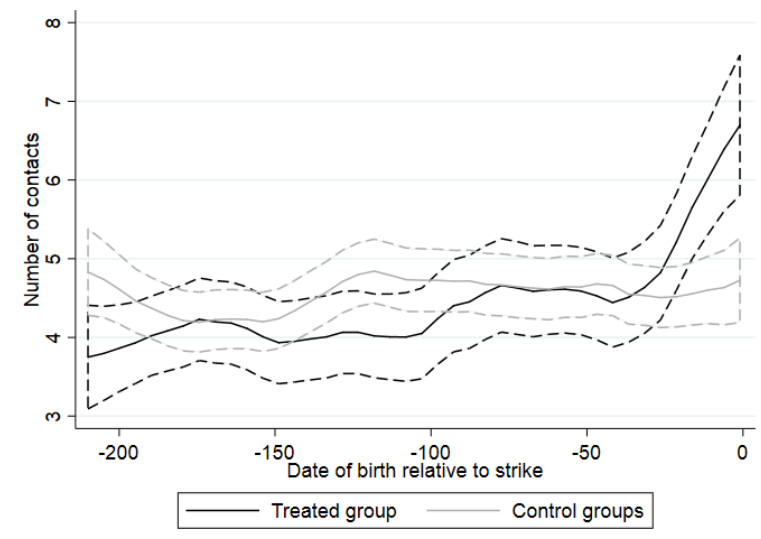

(a) Total GP contacts - one year

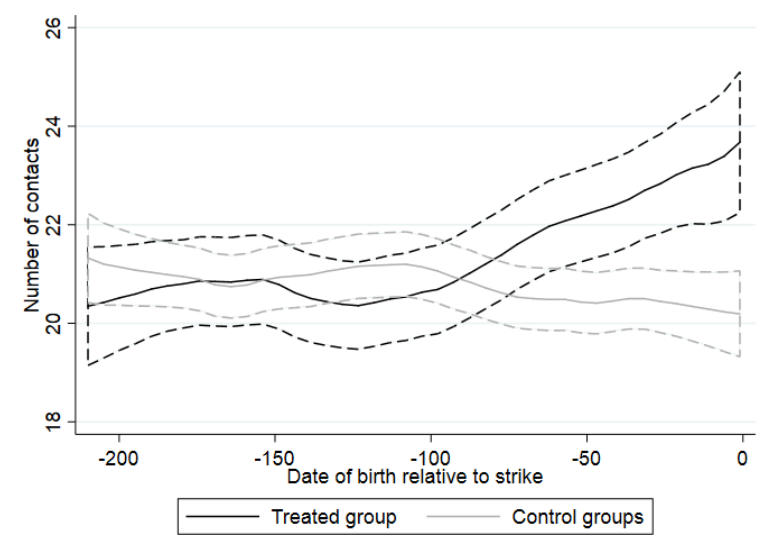

(c) Total GP contacts - three years

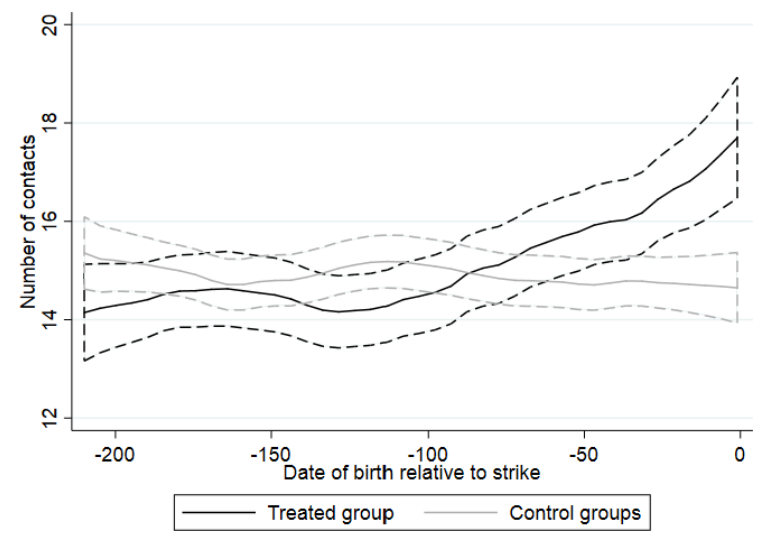

(b) Total GP contacts - two years

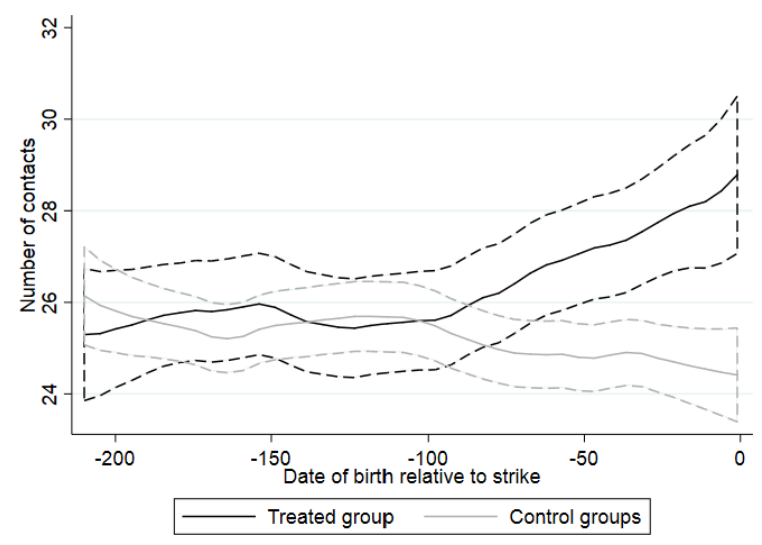

(d) Total GP contacts - four years

Fig. 3 Accumulated number of GP contacts for children born in the treated (September 18, 2007 - April 15, 2008) and control periods (September 17, 2008 and 2009 - April 15, 2009 and 2010) Notes: The figure shows the relationship between date of birth and accumulated total GP contacts. See Figure 2 for further details. 
Table 5 shows our main results for the impact of strike exposure on child health decomposed by the type of GP contact. To rule out that substitution toward GP visits during the first year of life drive our findings, we present estimates for yearly outcome measures, i.e., child GP contacts measured in each year of life of the child. ${ }^{32}$ Across periods the estimated effects are significant and the patterns documented in the graphical analysespersist: Children born in the 30-1 days age group have 1.8, 1.6 and 1.3 additional GP visits during the first, second and third to fourthyear of life. In percentageterms (evaluated at theaverage number of GP visits of the control group) our results translate to 40.3 percent, 15.5 percent and 12.4 percentincreases. Consideringemergency GP contacts, therelativeeffects arelarger at 50.0 percent, 18.4 percent and 18.2 percent during the first, second and third to fourth year of life. Children in the60-31 days agegroup havesignificantly more GP contacts (across types) in their second year of life. For all other age groups the timing of strike exposure has no significant effects on GP contacts.

To assess the impact of strike exposure at other margins, we havealso considered alternative measures of child health (Appendix TableA5): child hospitalizations and outpatient contacts. While most point estimates for first year hospitalizations are imprecise, we find suggestive evidence that early strike-exposed children are 7-8 percent-points (40 percent) more likely to be hospitalized during the second year of life. These results carefully support that our results for GP care and indicate actual health effects that do not exclusively reflect substitution and precautionary parental behavior. Furthermore, we see some indication for a decreasein firstyear outpatient contacts. Whilenursesin non-strikeyears can referfamilies as outpatients to hospitals in case of health or feeding issues, during the strike this option

\footnotetext{
${ }^{32}$ We have also estimated the regression equivalents of the graphs for the accumulated GP contacts for all years between year one and four in one combined graph. The effects on GP contacts increase as the child ages, in particular during the first two years of life. At age four, treated children have 4.6 (18.3 percent) more GP contacts in total for the 30-1 bin, 2.8 (11.1 percent) for the 60-31 bin and 2.4 (9.5 percent) for the 90-61 bin. For regular GP contacts the percentage effect is 15.8 percent for the youngest age groups and 8.1 percent for the 60-31 age bin (for the 90-61 age bin we see no significant effect on the number of regular GP contacts). The percentage effects on emergency contacts are 23.2 percent, 17.1 percent and 13.4 percent for the 30-1, 60-31 and 90-61 age bins.
} 
Table 5 Effects of strike exposure on child health: Yearly GP contacts by type

\begin{tabular}{|c|c|c|c|c|c|c|c|c|c|}
\hline & $\begin{array}{c}\text { (1) } \\
\text { Total GP } \\
\text { 1st year }\end{array}$ & $\begin{array}{c}(2) \\
\text { Total GP } \\
\text { 2nd year }\end{array}$ & $\begin{array}{c}(3) \\
\text { Total GP } \\
\text { 3-4 years }\end{array}$ & $\begin{array}{c}\text { (4) } \\
\text { Ordin. GP } \\
\text { 1st year }\end{array}$ & $\begin{array}{c}\text { (5) } \\
\text { Ordin. GP } \\
\text { 2nd year }\end{array}$ & $\begin{array}{c}\text { (6) } \\
\text { Ordin. GP } \\
\text { 3-4 years }\end{array}$ & $\begin{array}{c}\text { (7) } \\
\text { Emerg. GP } \\
\text { 1st year }\end{array}$ & $\begin{array}{c}\text { (8) } \\
\text { Emerg. GP } \\
\text { 2nd year }\end{array}$ & $\begin{array}{c}\text { (9) } \\
\text { Emerg. GP } \\
\text { 3-4 years }\end{array}$ \\
\hline \multicolumn{10}{|l|}{ Days } \\
\hline $180-151$ & $\begin{array}{r}0.469 \\
(0.516)\end{array}$ & $\begin{array}{c}0.129 \\
(0.515)\end{array}$ & $\begin{array}{c}0.707 \\
(0.597)\end{array}$ & $\begin{array}{c}0.142 \\
(0.348)\end{array}$ & $\begin{array}{c}-0.147 \\
(0.319)\end{array}$ & $\begin{array}{c}0.447 \\
(0.391)\end{array}$ & $\begin{array}{c}0.327 \\
(0.222)\end{array}$ & $\begin{array}{c}0.277 \\
(0.296)\end{array}$ & $\begin{array}{c}0.260 \\
(0.312)\end{array}$ \\
\hline $150-121$ & $\begin{array}{r}0.297 \\
(0.517)\end{array}$ & $\begin{array}{c}0.402 \\
(0.508)\end{array}$ & $\begin{array}{c}0.539 \\
(0.594)\end{array}$ & $\begin{array}{c}0.149 \\
(0.342)\end{array}$ & $\begin{array}{c}0.191 \\
(0.319)\end{array}$ & $\begin{array}{c}0.358 \\
(0.386)\end{array}$ & $\begin{array}{c}0.148 \\
(0.229)\end{array}$ & $\begin{array}{c}0.211 \\
(0.290)\end{array}$ & $\begin{array}{c}0.181 \\
(0.310)\end{array}$ \\
\hline 120-91 & $\begin{array}{c}-0.187 \\
(0.527)\end{array}$ & $\begin{array}{c}-0.161 \\
(0.492)\end{array}$ & $\begin{array}{c}0.007 \\
(0.564)\end{array}$ & $\begin{array}{c}-0.212 \\
(0.355)\end{array}$ & $\begin{array}{c}0.022 \\
(0.310)\end{array}$ & $\begin{array}{c}0.193 \\
(0.383)\end{array}$ & $\begin{array}{c}0.025 \\
(0.222)\end{array}$ & $\begin{array}{c}-0.183 \\
(0.283)\end{array}$ & $\begin{array}{l}-0.186 \\
(0.291)\end{array}$ \\
\hline $90-61$ & $\begin{array}{c}0.758 \\
(0.550)\end{array}$ & $\begin{array}{c}0.701 \\
(0.512)\end{array}$ & $\begin{array}{c}0.849 \\
(0.580)\end{array}$ & $\begin{array}{c}0.332 \\
(0.379)\end{array}$ & $\begin{array}{c}0.445 \\
(0.329)\end{array}$ & $\begin{array}{c}0.509 \\
(0.390)\end{array}$ & $\begin{array}{c}0.426^{*} \\
(0.223)\end{array}$ & $\begin{array}{c}0.255 \\
(0.284)\end{array}$ & $\begin{array}{c}0.340 \\
(0.303)\end{array}$ \\
\hline $60-31$ & $\begin{array}{c}0.364 \\
(0.529)\end{array}$ & $\begin{array}{c}1.707^{* * *} \\
(0.508)\end{array}$ & $\begin{array}{c}0.692 \\
(0.576)\end{array}$ & $\begin{array}{c}0.087 \\
(0.352)\end{array}$ & $\begin{array}{c}0.923^{* * *} \\
(0.321)\end{array}$ & $\begin{array}{c}0.408 \\
(0.381)\end{array}$ & $\begin{array}{c}0.277 \\
(0.227)\end{array}$ & $\begin{array}{c}0.783^{* * *} \\
(0.291)\end{array}$ & $\begin{array}{c}0.284 \\
(0.300)\end{array}$ \\
\hline $30-1$ & $\begin{array}{c}1.835^{* * *} \\
(0.555)\end{array}$ & $\begin{array}{c}1.614^{* * *} \\
(0.519)\end{array}$ & $\begin{array}{l}1.271^{* *} \\
(0.584)\end{array}$ & $\begin{array}{c}1.109^{* * *} \\
(0.376)\end{array}$ & $\begin{array}{c}0.977^{* * *} \\
(0.332)\end{array}$ & $\begin{array}{c}0.692^{*} \\
(0.394)\end{array}$ & $\begin{array}{c}0.726^{* * *} \\
(0.233)\end{array}$ & $\begin{array}{c}0.637^{* *} \\
(0.288)\end{array}$ & $\begin{array}{c}0.579 * \\
(0.296)\end{array}$ \\
\hline $\begin{array}{l}\text { Control } \\
\text { group } \\
\text { mean } \\
\text { Obs. }\end{array}$ & 12078 & 10.35 & 10.22 & 12078 & 11982 & 7.04 & 12078 & 11982 & 11709 \\
\hline
\end{tabular}


waslikely limited (dueto nurses in hospitals also beingon strike). ${ }^{33}$ Given that we do not see longer-run impacts of strike exposure on outpatient contacts, weconclude that our finding for outpatient care supports the idea of some substitution of care during the strike (from hospital care to GP care). ${ }^{34}$

Our main results show that early strike-exposure impacts children's number of GP contacts- in theshortandlongerrun. Importantly, nursesalso focustheirattention onmaternal physical and mental well-being. Table6 presents results formaternal (total and emergency) GP contacts, as well as (non-emergency) maternal contacts to psychologists and psychiatrists (after referrals from their GP). Finally, whilewealso consider maternal psychiatric hospital admission and outpatient contacts within the first two years after birth. However, this outcome is a very rare event limiting our ability to detect impacts given our design and sample size.

Table6 shows that mothers, who are strike-exposed shortly after the birth (90-1days) of theirchild, have1.8-2.6additional GPcontacts(9.5-13.6percentincreaseatthemean) during the second to fourth year of life but no additional visits in the first year. Also for mothers, the GP results are both driven by scheduled and emergency GP contacts. For ourmeasure of contacts to a psychologist or psychiatrist two years after birth, wefind that mothers with early strike exposure (30-1 days bin) are 3.6 percent-points more likely to have a contact with a specialist ( 72 percent). In sum, our results indicate that early strike-exposure that resulted in reduced access to early NHV has impactsalso on maternal psychical and mental

\footnotetext{
${ }^{\mathbf{3 3}}$ However, hospitals were obliged to ensure an adequate level of care provision.

${ }^{34} \mathrm{We}$ have also attempted to analyze child outcomes based on nurse registrations at age eight months and longer run outcomes: Constraining our sample to children who received the eight month visit, we do not find precise estimates for the impacts of strike exposure on child development at eight months. However, these analyses are based on around 40 percent of our main analysis. Considering longer-run outcomes, we have explored the impact of timing of strike exposure on the probability of delayed school start of children. We do not detect any effects. Given the age of the strike-exposed and control children, we cannot yet examine longer-run impacts of the 2008 strike on academic test scores (observed for the first time during grade two). Assessing the school entry examination of around 75 percent of the children in our sample, we do not see any impact of timing of strike exposure on child BMI or probability of being overweight. In our sample we likely lack power to analyze these outcome (given low level of obesity prevalence at around 7 percent). Furthermore, we miss 25 percent of children in our school entry records that only cover Copenhagen and thus do not include children, who move.
} 
Table 6 Effects of strike exposure on maternal health: GP contacts, postnatal psychiatric diagnoses and contacts with psychiatric specialists

\begin{tabular}{|c|c|c|c|c|c|c|}
\hline & $\begin{array}{c}\text { (1) } \\
\text { Total GP } \\
\text { 1st year mothers }\end{array}$ & $\begin{array}{c}(2) \\
\text { Total GP } \\
\text { 2-4 years mothers }\end{array}$ & $\begin{array}{c}\text { (3) } \\
\text { Emerg. GP } \\
\text { 1st year mothers }\end{array}$ & $\begin{array}{c}\text { (4) } \\
\text { Emerg. GP } \\
\text { 2-4 years mothers }\end{array}$ & $\begin{array}{c}\text { (5) } \\
\text { Psychologist } \\
\text { psychiatrist } \\
\text { two years }\end{array}$ & $\begin{array}{c}\text { (6) } \\
\text { Psych. hosp. adm. } \\
\text { and outpat. cont. } \\
\text { twoyears }\end{array}$ \\
\hline \multicolumn{7}{|l|}{ Days } \\
\hline $180-151$ & $\begin{array}{l}-0.087 \\
(0.375)\end{array}$ & $\begin{array}{c}-1.325 \\
(0.986)\end{array}$ & $\begin{array}{c}0.007 \\
(0.097)\end{array}$ & $\begin{array}{c}0.046 \\
(0.217)\end{array}$ & $\begin{array}{c}0.025 \\
(0.016)\end{array}$ & $\begin{array}{l}-0.002 \\
(0.002)\end{array}$ \\
\hline $150-121$ & $\begin{array}{c}0.024 \\
(0.371)\end{array}$ & $\begin{array}{c}1.205 \\
(0.984)\end{array}$ & $\begin{array}{c}0.067 \\
(0.103)\end{array}$ & $\begin{array}{c}0.204 \\
(0.210)\end{array}$ & $\begin{array}{c}0.024 \\
(0.015)\end{array}$ & $\begin{array}{c}0.003 \\
(0.003)\end{array}$ \\
\hline $120-91$ & $\begin{array}{c}0.439 \\
(0.394)\end{array}$ & $\begin{array}{c}0.802 \\
(1.013)\end{array}$ & $\begin{array}{c}0.015 \\
(0.098)\end{array}$ & $\begin{array}{c}0.250 \\
(0.215)\end{array}$ & $\begin{array}{l}-0.001 \\
(0.015)\end{array}$ & $\begin{array}{l}-0.000 \\
(0.002)\end{array}$ \\
\hline $90-61$ & $\begin{array}{c}0.366 \\
(0.390)\end{array}$ & $\begin{array}{l}2.355^{* *} \\
(1.019)\end{array}$ & $\begin{array}{c}0.124 \\
(0.096)\end{array}$ & $\begin{array}{c}0.633^{* * *} \\
(0.225)\end{array}$ & $\begin{array}{c}0.025 \\
(0.016)\end{array}$ & $\begin{array}{c}0.005 \\
(0.003)\end{array}$ \\
\hline $60-31$ & $\begin{array}{c}0.274 \\
(0.399)\end{array}$ & $\begin{array}{l}1.862 * \\
(1.034)\end{array}$ & $\begin{array}{l}0.215^{*} \\
(0.121)\end{array}$ & $\begin{array}{c}0.702^{* * *} \\
(0.228)\end{array}$ & $\begin{array}{c}0.019 \\
(0.016)\end{array}$ & $\begin{array}{l}0.008^{* *} \\
(0.003)\end{array}$ \\
\hline $30-1$ & $\begin{array}{c}0.506 \\
(0.391)\end{array}$ & $\begin{array}{c}2.664^{* * *} \\
(1.007)\end{array}$ & $\begin{array}{c}0.124 \\
(0.097)\end{array}$ & $\begin{array}{c}0.585^{* * *} \\
(0.217)\end{array}$ & $\begin{array}{l}0.036^{* *} \\
(0.016)\end{array}$ & $\begin{array}{c}0.001 \\
(0.002)\end{array}$ \\
\hline Control group mean & 7.29 & 19.92 & 0.70 & 1.97 & 0.05 & 0.00 \\
\hline Obs. & 12078 & 11698 & 12078 & 11698 & 11982 & 11982 \\
\hline
\end{tabular}

Notes: See notes for Table 3. Robust standard errors in parentheses. ${ }^{* * *} \mathrm{p}<0.01,{ }^{* *} \mathrm{p}<0.05$ and ${ }^{*} \mathrm{p}<0.10$. 
health. Moreover, effects on maternal well-being may constitute a mechanism for or reinforce the health effects on children that we have documented.

\subsection{Mechanisms}

Our main analyses show that early strike-exposure matters for child and maternal health. We interpret this finding as support for the hypothesis that early NHV matters more for the considered health outcomes than later visits. To speak to potential mechanisms for the observed effects, we focus on the elements of the composite nurse treatment that are of particular importance in the initial visits: information and counseling, and screening and monitoring of infant and maternal health. First, to assess the importance of information and counseling in explaining the negative effects of forgoing an early nurse visit, we study heterogeneous effects across two relevant dimensions: the parity of the childand parental health-related education. ${ }^{35}$ Specifically, wehypothesizethat first-time parents and parents without professional knowledge about child health and development may see larger effects of early strike exposure if information is an important element that strike-exposed parents lack.

For brevity, we present results for our measure of total GP contacts in year one and year two through four of the child's life. ${ }^{36}$ Wesplit our sample into subgroups and additionally estimate a fully interacted model on the full sample. Appendix TableA6 presents our splitsampleresults. ${ }^{37}$ Column (1)-(4) showregression results for samples divided into groups of parents with and without an education in a health field. While we do not find significant effects of the timing of strike-exposure for children of parents educated in a health-related

field, for children of parents not educated in those fields, our results resemble the main results. Similarly, first-born children seestronger effectsof earlystrikeexposureandalarger gradientthan higherparitychildren asshownin column(5)-(8) inAppendix TableA6. While

\footnotetext{
${ }^{35}$ The group with parents educated in health include children who have at least one parent educated as either a medical doctor, midwife, nurse or pedagogue.

${ }^{36}$ Results for emergency GP contacts only are available on request.

${ }^{37}$ Appendix Figure A6 presents the raw relationship between the timing of strike exposure and GP contacts accumulated at age four divided by parental health education and parity.
} 
weformally cannot reject thenull hypothesis that the effects are the sameacross subgroups (see Appendix TableA7), our findings suggest that an information and counseling channel is important for explaining longer-run health impacts of early NHV. At the same time, as illustrated in Appendix Table A8, we find less systematic differences in estimates across families of high or low socio-economic status, if anything, high SES families appear tosee larger effects of earlystrikeexposure ${ }^{38}$ Thisfindingmay furtherunderlinetheimportanceof specific guidance and information for new parents and, additionally, points to the potential importance of another channel for early life NHV, namely universal screening and health monitoring.

EarlyNHVputsafocus onscreeningforpotential healthproblemsininfantsandmothers: Offered as a universal program, it represents an early window of opportunity to detect and confront health problems. Our results for maternal mental health in Table 6 suggest that lack of early screening negatively impacts maternal mental health. Another way offurther examiningtheimportanceof screeningisto assess theperformance of nurses with respect to screening in non-strike years.

Figure 4 presents nurse registrations, referrals and maternal health care usage fortwo groups of mothers in our control year data: first, mothers with registrations of maternal mental health problems at theinitial visit (10 percent of mothers) and without those registrations. Conditional on havingfollow-upvisits, weobserveinterestingpatterns thatpointto theimportance of nursescreeningsveryshortlyafterbirth: Nursesaremorelikelyto register mental health problemsinlatervisitsfor early-detectedmothers. Additionally, motherswith early detected mental health problems receive more referrals to other health professionals and, importantly, among early-detected mothers there is a higher prevalence of externally measured mental health issues.

\footnotetext{
${ }^{38}$ Appendix Table A8 also examines heterogeneity by gender, child initial health, and parental risky behaviors (proxied by maternal smoking during pregnancy). We see indication for boys, children with poor initial health and children of parents with risky parental behavior being relatively more affected by the absence of early NHV (however, also in these analyses, we cannot reject equality of effects in most cases).
} 


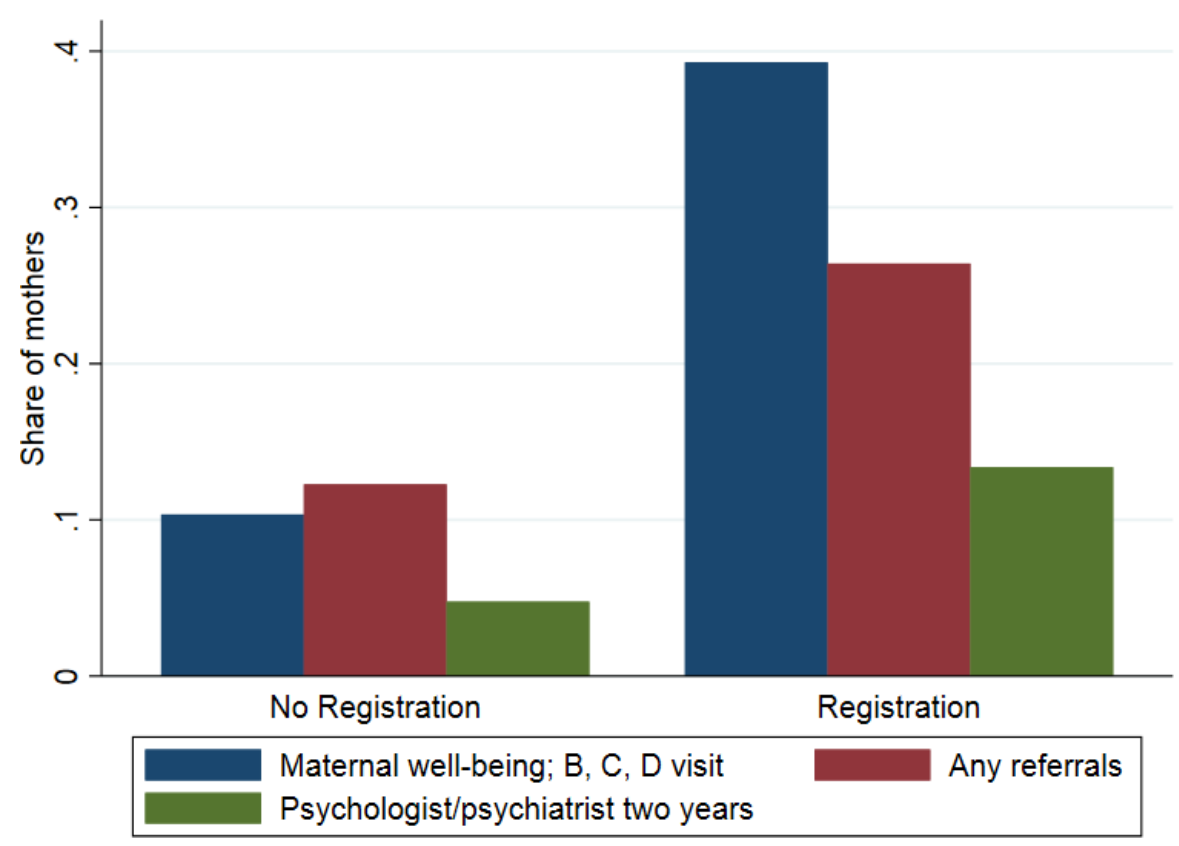

Fig. 4 Share of mothers with nurse registrations, referrals and contacts to psychologists/psychiatrists by registered maternal well-being concerns (0/1) at initial nurse visit, mothers of children born in the control period.

Notes: This figure divides mothers of control children (born in Copenhagen between September 17, 2008 April 15, 2009) into two groups: The 10 percent of mothers with nurse registrations in their initial nurse visit (concerned about maternal well-being vs not concerned) and the 90 percent of mothers without a registered concern. We constrain the control sample to mothers, who received the initial visit and plot the share of mothers who receive registrations of maternal well-being issues at later visits (B, C and D), the share who are referred to other health care professionals by nurses, and the share for whom we observe any contacts with psychologists/psychiatrists up to two years after their birth.

Relating Figure 4 to the overall prevalence of maternal mental-health related contacts, our calculations suggest that nurses during their first visit identify up to one out of four of thosemothers who end up havingamental-health related contact with specialistsin thefirst twoyears of their child'slife. ${ }^{39}$ Thisillustrativefiguresuggestslarge potential health returns from early screening efforts.

A final and important potential pathway for the effect of early NHV are parental investments in response to those. Nurses provideinformation and guidance about issues such as

\footnotetext{
${ }^{39}$ Nurses screen around 10 percent of mothers in the sample as having a mental health problem. Of those, 13 percent end up having at least one psychologist/psychiatrist contact in the first three years of the child's life. In the population, the prevalence of those contacts is around 5 percent. These figures suggest that nurses may capture around 20 percent of those mothers, who end up with a contact.
} 
other availablehealth care services, appropriateinteractions with children at differentages, and aspects such as sleep and child feeding. However, given our sample sizein combination with our empirical strategy, we are constrained in an analysis of those parental behaviors: Appendix Tables A9 and A10 study whether strike exposure impacts participation in the childhood preventive care program and vaccination program participation as outcomes. ${ }^{40}$ As the tables illustrate, we cannot draw firm conclusions due to very imprecise estimates.

\subsection{Robustness Tests}

Our main results are robust to a number of changes to our main specification and sample. For brevity, we only present robustness tests using our yearly measures of child GP contacts as outcome in the appendix material. Weshow that our conclusions are not sensitive to the omission of individual-level control variables (Appendix TableA11) and reasonablealternative choices of bin size (Appendix Tables A12 and A13). To rule out that our measure of strikeexposurecaptures other factors, weimplementa set of placebo regressions: Appendix TableA14 shows estimates from those regressions where we define "treated" children as those born 210 days prior to April 15, 2009 (theyear after thestrike). Wefind no significant effects of strike exposure in the placebo regressions.

In additional robustnesstests, wehavehaveruled out that includingmoversfrom Copenhagen alters our conclusions and confirmed that they are robust to theimplementation of a doughnut hole approach (where we drop children born within 20 days of strike start, who were likely to loose more than one visit on average). By using earlier cohorts of children as a control group, by examining theimpact of strike exposure on children aged fiveduring the strike, and by constraining our main analysis to using data from the years 2008 and 2009 (our "first stage" sample), we confirm that our choices of control and treatment groups do

\footnotetext{
${ }^{\text {10 }} \mathrm{Almost} 80$ percent of children receive all infant vaccinations and each round of vaccinations are attended by 90 percent of children in Copenhagen. Participation in the vaccination program is voluntary and the decision ultimately rests at the parents. The DNBH specifically mentions nurse visits as a central strategic element to promote the benefits of vaccinations to parents (The Danish National Board of Health [Sundhedsstyrelsen], 2018). The DNBH report highlights the close relationship between the families and their assigned nurse which facilitates dialogue if parents are in doubt or have chosen not to participate.
} 
not drive our findings. Our main conclusions-that earlier strike exposure is relative more important for children's health-remain intact across these iterations. ${ }^{41}$

\section{Costs and Benefits}

In this section, we perform a stylized analysis of immediate health benefits and the costs of early NHV (relative to later NHV). Specifically, we relate the value of prevented GP visits for mothers and children to the costs of those visits. Given the most consisten evidence for an impact of the strike on the health of children and mothers exposed early, wefocus in the following on the initial and two-month nurse visits. The assessment of the benefits of early visits is-due to our design - always relative to the benefits of later visits. Put differently, in our calculations, we assume that the the benefits of the later visits are zero.

Benefits Appendix Table A15 presents results for the impact of strike exposure on GP fees (for both mother and child) at age four. ${ }^{42}$ As we disregard longer-run benefits, such as prevented child hospital admissions, and potential spill-over effects to other domains, such as child cognitive development or maternal timely return to the labor market, our measure of benefits (prevented GP costs) is likely very conservative.

Children born in the 30-1 and 60-31 days age groups (and their mothers) have significantlyhigher GP expenses, in linewith ourfinding of increased GP contactsfor thesegroups. Specifically, children and mothers impacted by the strike in the given groups have, respectively, 154.3 and 94.2 EUR higher GP expenses at age four. To translate these costs (or the benefit from preventing them) into a measure directly linked to a forgone visit, we scale the reducedformestimates with theprobability ofmissingthespecificvisitsfor thegivengroups of children and mothers. ${ }^{43}$ Thus weestimate the benefits of theinitial nursevisit and the two

\footnotetext{
IIAll mentioned robustness tests for yearly GP and other outcomes are available on request.

${ }^{\mathbf{4 2}} \mathrm{GPs}$ are reimbursed for all procedures they provide to patients in a given calendar week. We do not find clear evidence for the treated children having more costly GP visits on average.

${ }^{\mathbf{4 3}}$ For the first group (children born 30-1 days prior to strike) both the probability of not receiving the initial and two-months visits are increased by 17.1 and 32.3 percentage points, respectively (see Table 3 ). Thus
} 
months nurse visit as 554.2 EUR and 184.3 EUR (prevented GP costs for child and mother up to the child's four year birthday).

Costs To quantify costs of a home visit, we only consider the direct costs related to nurses' salaries. ${ }^{45}$ Additionally, we assume that all types of home visits have the same average cost. We calculate the cost of a home visit in two different ways that allow us to bound our calculations: first, we conservatively assume that municipal nurses spend all working time on homevisits. Second, in the alternative scenario weincorporate that nurses have other tasks beyond home visits (such as supervision of school children, consultancy and phone hours, team meetings, administrative tasks).

We estimate the weekly number of canceled visits during the strike to be $760 .{ }^{46} \mathrm{Af}-$ ter the strike, the municipality of Copenhagen reported daily savings during the strike of 35,500 EUR per workday or 177,500 EUR per (business) week (because the municipality did not pay salaries to the unionized nurses on strike). For our most conservative measure of costs per visit, we divide the weekly divided by the weekly number of canceled visits, 177, 500 EUR/760 visits = 233.6 EUR per visit. For our alternative measure - that takes into account that nurses also have other obligations-we adjust the share of working hours nurses dedicate to home visiting to 55 percent. ${ }^{47}$ Dividing the weekly savings during the strike adjusted with the actual time spent on home visits by the number of canceled visits,

to calculate the benefit of the initial visit, we scale the increase in GP fees for the 30-1 day group with the increase in their risk of missing the initial visit while subtracting the share of their increase in GP fees that can be attributed to the higher probability of also missing the two month visit: $154.3-184.3 \times 0.323$ )/0.171= 554.2 EUR. ${ }^{\mathbf{A 4}}$ For the 60-31 day age group only the probability of missing the second nurse visit was impacted by the strike (51.1 percentage points). Thus, we scale their increase in GP fees due to strike exposure with the increase in the risk of forgoing the two month visit: 94.2/0.511 = 184.3 EUR.

${ }^{\mathbf{4 5}} \mathrm{We}$ abstract from any fixed and variable costs beyond salaries to nurses. Examples of fixed costs are the education of nurses, capital (cars, building stock and software). Variable costs beyond salaries to nurses are management costs, cleaning services, transportation, lunch and coffee among others.

${ }^{46}$ In our nurse data we observe that, during the full seven weeks of the strike, 85 weekly nurse visits were preformed. In the equivalent weeks of the following year, the weekly average of visits was 845 . We assume that the difference in weekly visits equals the number of canceled visits caused by the strike $(845$ - 85 = 760).

${ }^{\mathbf{4 7}}$ In our data for the control period, 155 nurses performed visits implying that the average nurse had $845 / 155=5.5$ weekly visits. Assuming that one visit lasts 1.5 hours and that nurses spend an additional1.5 hours on preparation, transportation and registration, nurses spend 5.5 visits $\times 1.5$ hours at actual visit $\times$ 1.5 hours for tasks related to visit $=16.5$ hours weekly on NHV. If we assume that the average nurse work 30 hours per week, we estimate that nurses spend $16.5 / 30=55$ percent of their working time on NHV. 
we find that the cost of a home visit in our alternative scenario is $128 \mathrm{EUR}^{48}$

Comparing costs and benefits In both described scenarios for ourcalculations of costs, theinitial nursevisit has a positive return of between 330.6 and 425.7 EUR. This represents a substantial return given that we only included savings related to GP care and under the fairlyconservativeassumption that thefourmonthand eightmonthvisitshavezerobenefits. For the two month visit, we conclude that the return only related to prevented GP costs is between -39.3 and 55.8 EUR. Thus our simple analysis indicates that early universal NHV is a cost-effectiveintervention. Our estimates highlight theimportance of timing: Whilethe cost of an initial visit is considerably lower than the associated health care savings at age four, the difference in the increase in GP fees and the savings from canceling a two month visit is considerably smaller.

\section{Conclusion}

Using nurse records linked to administrative data and exploiting exogenous variation induced by a national strike, we provide causal evidence on the impact of timing of early life health investments on child and maternal health. Thus our analysis of the effects of NHV moves beyond the extensive margin of treatment exposure. Studying the Danish universal program, we find that early NHV (during the initial weeks and first two months of the child's life) impacts both child and maternal health trajectories (measured in our analyses as health care usage). Weconcludethatearliervisitsaremoreimportant forchildren'sand mother's health than later visits. While we cannot fully disentangle underlying reasons for increased health care usage for children and their mothers, we show that access to early NHV impacts emergency GP contacts and children's hospitalization-also when we omit first year outcomes. Both findings point to actual health effects rather than substitution.

The heterogeneity of effects by parental health knowledge and child parity point to the

${ }^{\text {48 }}(177.500$ EUR $\times 55$ percent $) / 760$ visits $=128$ EUR per visit 
importance of information and parental confidence as a channel for health effects-supporting both is at the core of early home visits. While we do not directly observe parental beliefs and only have few measures of actual parental investment behaviors, both factors may be contributing to the effects of early home visits that we find.

Importantly, indicating theimportance of timely screening for child and maternal health issues, we find that early NHV also plays a role for maternal postpartum mental health. As a consequence, our results imply that early home visits are likely to impact children through theirimpact on mothers: Existingresearch documentsstrongcorrelations between maternal postnatal mental health and child outcomes in different domains, and highlightsthe importance of early detection of maternal mental health problems. Thus early universal home visits can play an important rolein securing population maternal and child health through the prevention of undetected and hence untreated mental health problems. In this aspect, our study echoes the finding of other recent work pointing to the importance of supporting the health of new mothers.

Finally, while initial visits in the Danish program focus on mother and infant physical health, infant feeding and sleep patterns, and maternal mental well-being, later nursevisits increasingly focus on other and more diverse domains of child development and parent-child interactions. In our setting, wedo notfind that thoselatervisitsimpact thehealth outcomes that we can study. However, these visits may play an important role in further shaping parental investments and child development in other domains. We leave this topic as an important alley for future research. 


\section{References}

Almond, D. and J . Currie (2011). Killing me softly: The fetal origins hypothesis. Journal of Economic Perspectives 25 (3), 153- 72.

Almond, D.,J . Currie, and V. Duque (2018). Childhood circumstances and adult outcomes: Act ii. Journal of Economic Literature 56 (4), 1360- 1446.

Anderson, M. L. (2008). Multipleinferenceand gender differences in the effects of early intervention: Areevaluation of theabecedarian, perrypreschool, and earlytrainingprojects. Journal of the American Statistical Association 103 (484).

Angrist, J. D. and J.-S. Pischke (2008). Mostly Harmless Econometrics: An Empiricist's Companion. Princeton University Press.

Attanasio, O., S. Cattan, E. Fitzsimons, C. Meghir, and M. Rubio-Codina (2015, February). Estimatingtheproductionfunctionforhuman capital: Resultsfromarandomized control trial in colombia. Working Paper 20965, National Bureau of Economic Research.

Attanasio, O. P., C. Fernández, E. O. Fitzsimons, S. M. Grantham-McGregor, C. Meghir, and M. Rubio-Codina (2014). Using theinfrastructure of a conditional cash transfer program to deliverascalableintegrated earlychild development programin colombia: cluster randomized controlled trial. BMJ 349, g5785.

Baranov, V., S. Bhalotra, P.Biroli, andJ . Maselko(2019). Maternal depression, women'sempowerment, and parental investment: Evidencefrom arandomized control trial. American Economic Review.

Belfield, C. R., M. Nores, S. Barnett, and L. Schweinhart (2006). The high/ scope perry preschool program cost- benefit analysis using data from the age- 40 followup. Journal of Human Resources 41 (1), 162- 190. 
Bhalotra, S., M. Karlsson, and T. Nilsson (2017). Infanthealth and longevity: Evidencefrom a historical intervention in sweden. Journal of the European Economic Association 15 (5), 1101- 1157.

Biroli, P., T. Boneva, A. Raja, and C. Rauh (2018). Parental beliefs about returns to child health investments.

Boneva, T. and C. Rauh (2018). Parental beliefs about returns to educational investments-the later the better? Journal of the European Economic Association 16 (6), 16691711.

Bütikofer, A., K. V. Løken, and K. G. Salvanes (2019). Infant health care and long-term outcomes. Review of Economics and Statistics 101 (2), 341- 354.

Butikofer, A., J . Riise, and M. Skira (2018). Theimpact of paid maternity leaveon maternal health. NHH Dept. of Economics Discussion Paper (04).

Campbell, F., G. Conti, J. J . Heckman, S. H. Moon, R. Pinto, E. Pungello, and Y. Pan (2014). Early childhood investments substantially boost adult health. Science 343 (6178), 1478- 1485.

Carneiro, P. and R. Ginja (2014). Long-term impacts of compensatory preschool on health and behavior: Evidence from head start. American Economic Journal: Economic Policy 6 (4), 135- 73.

Cascio, E. U. (2009). Do investments in universal early education pay off? long-term effects of introducingkindergartens into public schools. Working Paper 14951, National Bureau of Economic Research.

Cascio, E. U. (2015). The promises and pitfalls of universal early education. IZA World of Labor . 
Conti, G., J .J . Heckman, and R. Pinto (2016). The effects of two influential early childhood interventions on health and healthy behaviour. The Economic Journal 126 (596), F28- F65.

Cooper, P. J . and L. Murray (1998). Postnatal depression. BMJ 316 (7148), 1884- 1886.

Cunha, F., I. Elo, and J . Culhane (2013, J une). Eliciting maternal expectations about the technology of cognitive skill formation. Working Paper 19144, National Bureau ofEconomic Research.

Currie, J . and D. Thomas (1995). Does head start make a difference? American Economic Review 85 (3), 341- 364.

DeHaan, M. and E. Leuven (2016). Head start and the distribution of long term education and labor market outcomes. Technical report, CESifo Working Paper No 5870.

Deming, D. (2009). Early childhood intervention andlife-cycleskill development: Evidence from head start. American Economic Journal: Applied Economics, 111- 134.

Doyle, O., N. Fitzpatrick, J . Lovett, and C. Rawdon (2015). Early intervention and child physical health: Evidence from a dublin-based randomized controlled trial. Economics $\mathcal{E}$ Human Biology 19, 224 - 245.

Due, J. J. and J. S. Madsen (2008). Forligsmagere og Forumshoppere - Analyse af OK 2008 i Den Offentlige Sektor. J urist- og Økonomforbundets Forlag.

Garces, E., D. Thomas, andJ . Currie(2002). Longer-term effects of head start. The American Economic Review 92 (4), 999- 1012.

García, J . L., J .J . Heckman, D. E. Leaf, and M.J . Prados (2016). Thelife-cyclebenefits of an influential early childhood program. WorkingPaper22993, National Bureau of Economic Research. 
García, J . L., J . J . Heckman, and A. L. Ziff (2017, May). Gender differences in the benefits of an influential early childhood program. Working Paper 23412, National Bureau of Economic Research.

Gertler, P., J . Heckman, R. Pinto, A. Zanolini, C. Vermeersch, S. Walker, S. M. Chang, and S. Grantham-McGregor (2014). Labor market returns to an early childhood stimulation intervention in jamaica. Science 344 (6187), 998- 1001.

Heckman, J ., S. H. Moon, R. Pinto, P. Savelyev, and A. Yavitz (2010a). Analyzing social experiments as implemented: A reexamination of the evidence from the highscopeperry preschool program. Quantitative Economics 1 (1), 1- 46.

Heckman, J., R. Pinto, and P. Savelyev (2013). Understanding the mechanisms through which an influential early childhood program boosted adult outcomes. American Economic Review 103 (6), 2052- 86.

Heckman, J . J ., S. H. Moon, R. Pinto, P. A. Savelyev, and A. Yavitz (2010b). The rate of return to the highscope perry preschool program. Journal of Public Economics 94 (1), 114- 128.

Hjort, J., M. Sølvsten, and M. Wüst (2017). Universal investment in infants and longrun health: Evidence from denmark's 1937 home visiting program. American Economic Journal: Applied Economics 9 (4), 78- 104.

Ibsen, C. L., T. P. Larsen, J. S. Madsen, and J . Due (2011). Challenging scandinavian employment relations: the effects of new public management reforms. The International Journal of Human Resource Management 22 (11), 2295- 2310.

Kronborg, H., H. H. Sievertsen, and M. Wüst (2016). Care around birth, infant and mother health and maternal health investments - evidencefrom a nursestrike. Social Science and Medicine 150, 201- 211. 
Lovejoy, M. C., P. A. Graczyk, E. O’Hare, and G. Neuman (2000). Maternal depression and parenting behavior: A meta-analytic review. Clinical Psychology Review 20(5), 561- 592.

Ludwig, J . and D. Miller (2007). Does head start improve children's life chances? evidence from a regression discontinuity design*. The Quarterly Journal of economics 122 (1), 159208.

Masse, L. N. and W. S. Barnett (2002). A benefit-cost analysis of the abecedarian early childhood intervention. Cost-Effectiveness and Educational Policy, Larchmont, NY: Eye on Education, Inc, 157- 173.

Olds, D. L., C. R. Henderson, R. Chamberlin, and R. Tatelbaum (1986). Preventing child abuse and neglect: A randomized trial of nurse homevisitation. Pediatrics 78(1), 65- 78.

Olds, D. L., C. R. Henderson, R. Cole, J . Eckenrode, D. Kitzmann, Harriet Luckey, L. Pettitt, K. Sidora, P. Morris, and J. Powers (1998). Long-term effects of nurse homevisitation on childrens criminal and antisocial behavior: 15-year follow-up of a randomized controlled trial. JAMA 280 (14), 1238- 1244.

Olds, D. L., J. Robinson, R. O’Brien, D. W. Luckey, L. M. Pettitt, C. R. Henderson, R. K. Ng, K. L. Sheff, J . Korfmacher, S. Hiatt, and A. Talmi (2002). Home visiting by paraprofessionals and by nurses: A randomized, controlled trial. Pediatrics 110 (3), 486- 496.

Paulson, J . F., S. Dauber, and J . A. Leiferman (2006). Individual and combined effects of postpartum depression in mothers and fathers on parenting behavior. Pediatrics 118(2), 659-668.

Persson, P. and M. Rossin-Slater (2019). When dad can stay home: Fathers' workplace flexibility and maternal health. Technical report, National Bureau of EconomicResearch.

Sandner, M.(2019). Effectsofearlychildhoodintervention on fertilityandmaternal employment: Evidence from a randomized controlled trial. Journal of Health Economics 63, 159 $-181$. 
Sandner, M., T. Cornelissen, T.J ungmann, and P.Herrmann (2018). Evaluating the effects of a targeted home visiting program on maternal and child health outcomes. Journal of Health Economics 58, 269 - 283.

Schweinhart, L. J ., J . Montie, Z. Xiang, W. S. Barnett, C. R. Belfield, and M. Nores (2005). Lifetime effects: The High/Scope Perry Preschool study through age 40. Ypsilanti, MI: High/ Scope Press.

Sundhedsstyrelsen (2007). Primary preventivecarefor children andyouth - national guidelines [forebyggende sundhedsordninger for børn og unge - retningslinier]. Technical report, The Danish National Board of Health.

The Danish National Board of Health [Sundhedsstyrelsen] (2018). The child vaccination program - yearly report 2017 [børnevaccinationsprogrammet - Årsrapport 2017. Technical report, The Danish National Board of Health.

Thompson, O. (2017). Head start'slong-runimpact: Evidencefrom theprogram'sintroduction. Journal of Human Resources, 0216- 7735r1.

Vaithianathan, R., M. Wilson, T. Maloney, and S. Baird (2016). The Impact of the Family Start Home Visiting Programme on Outcomes for Mothers and Children: A QuasiExperimental Study. Ministry of Social Development.

Wachs, T. D., M. M. Black, and P. L. Engle (2009). Maternal depression: a global threat to children's health, development, and behavior and to human rights. Child Development Perspectives 3 (1), 51- 59.

Wüst, M. (2012). Early interventions and infant health: Evidence from the danish home visiting program. Labour Economics 19, 484- 495. 


\section{A Appendix - For online publication}

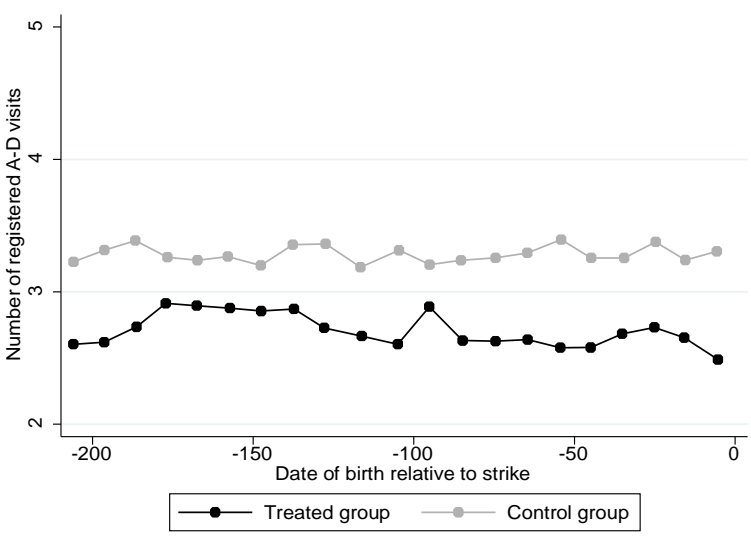

(a) Universal nurse visits

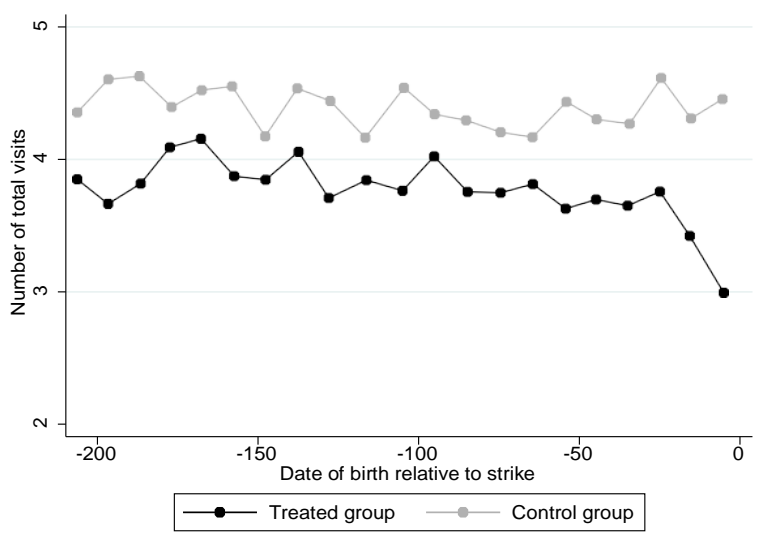

(b) Total nurse visits (universal + extra)

Fig. A1 Average number of universal and total nurse home visits for children in the treated and control period

Notes: Average number of visits is calculated for children in (September 18, 2007 - April 15, 2008) and control period (September 17, 2008 - April 15, 2009) in 21 equally sized 10-day bins. 


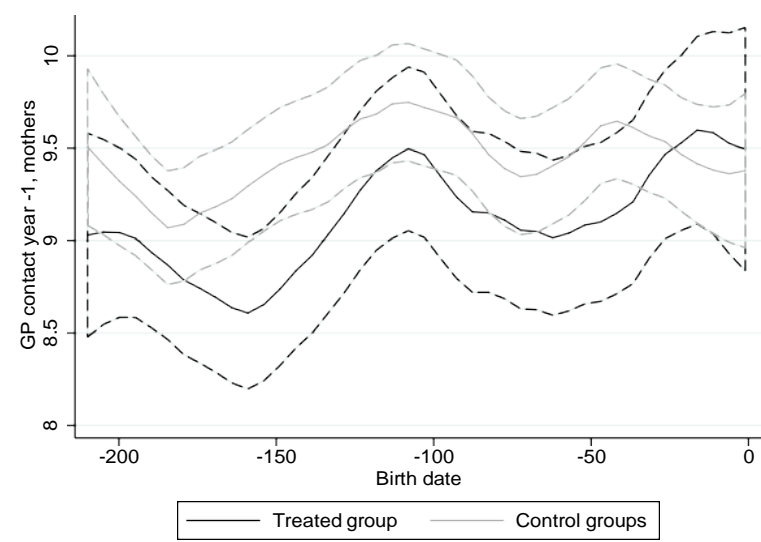

(a) Mothers GP contacts, 365 days prior birth

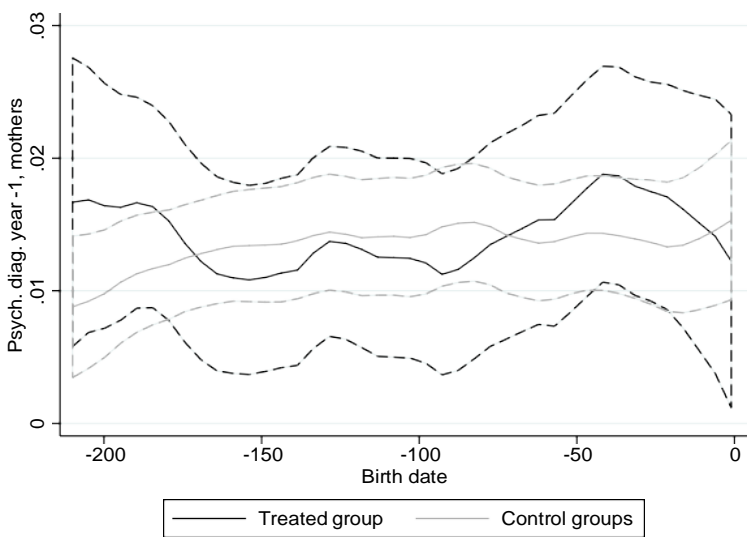

(b) Mother psychiatric diagnosis, prior to birth

Fig. A2 Common trend in pre-treatment health outcome: Number of mothers' GP contacts (a) and indicator if mother received a psychiatric diagnosis (b) in the year prior to birth Notes: Se notes to Figure 3. Treated period: September 18, 2007 - April 15, 2008. Control period: September 17, 2008 and 2009 - April 15, 2009 and 2010). 


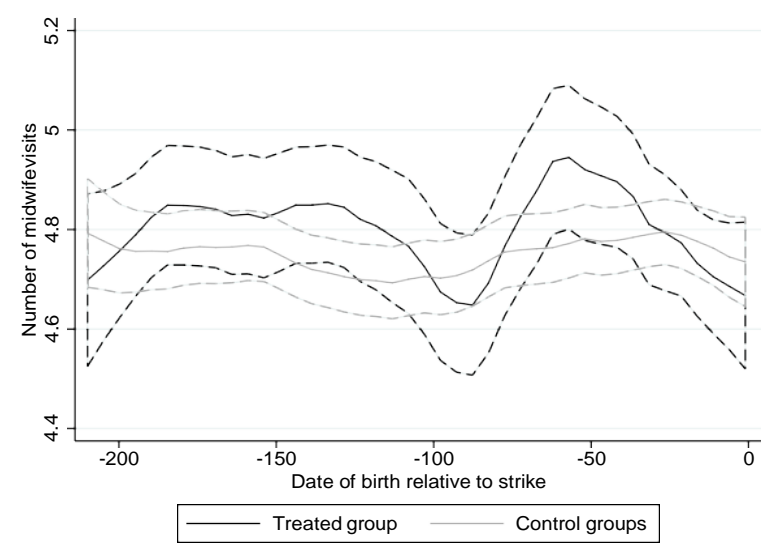

(a) Midwife visits

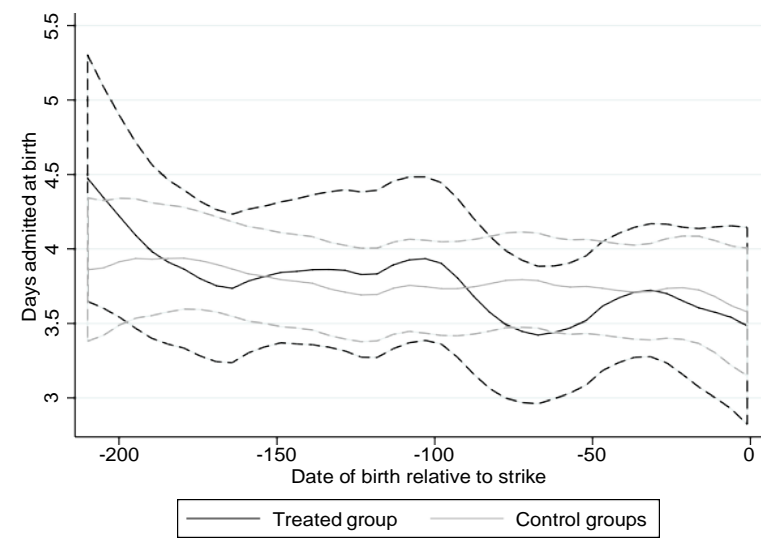

(c) Days admitted at birth

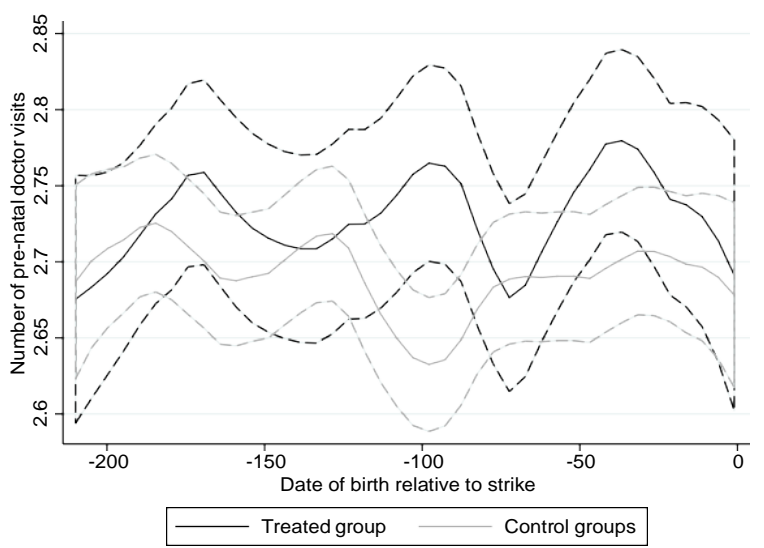

(b) Prenatal GP contacts

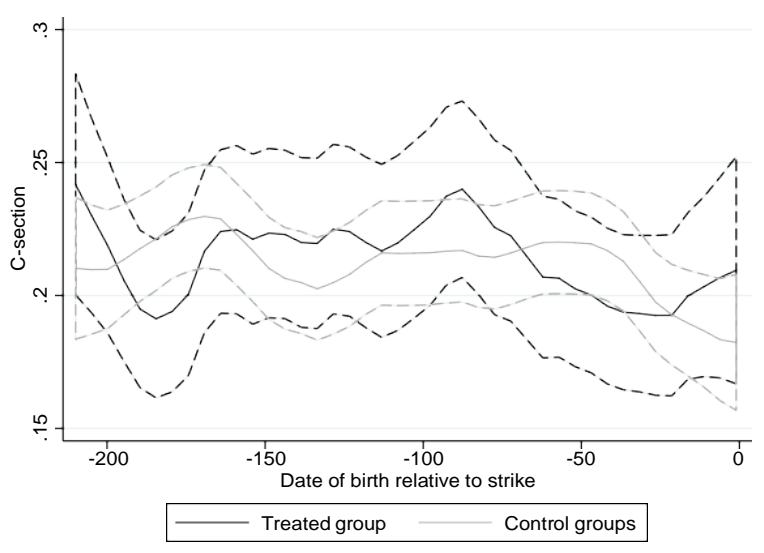

(d) C-sections

Fig. A3 Care around birth for the treated period and control periods

Notes: Panel (a) shows thenumber of prenatal midwifecontacts, panel (b) shows thenumber of prenatal GP consultations, panel (c) shows the number of days admitted to hospital at birth and panel (d) shows the C-section rate. See notes to Figure 3. The sample includes children who were born in Copenhagen in the treated period (September 18, 2007- April 15, 2008) and control periods (September 17, 2008 and 2009 - April 15, 2009 and 2010). 


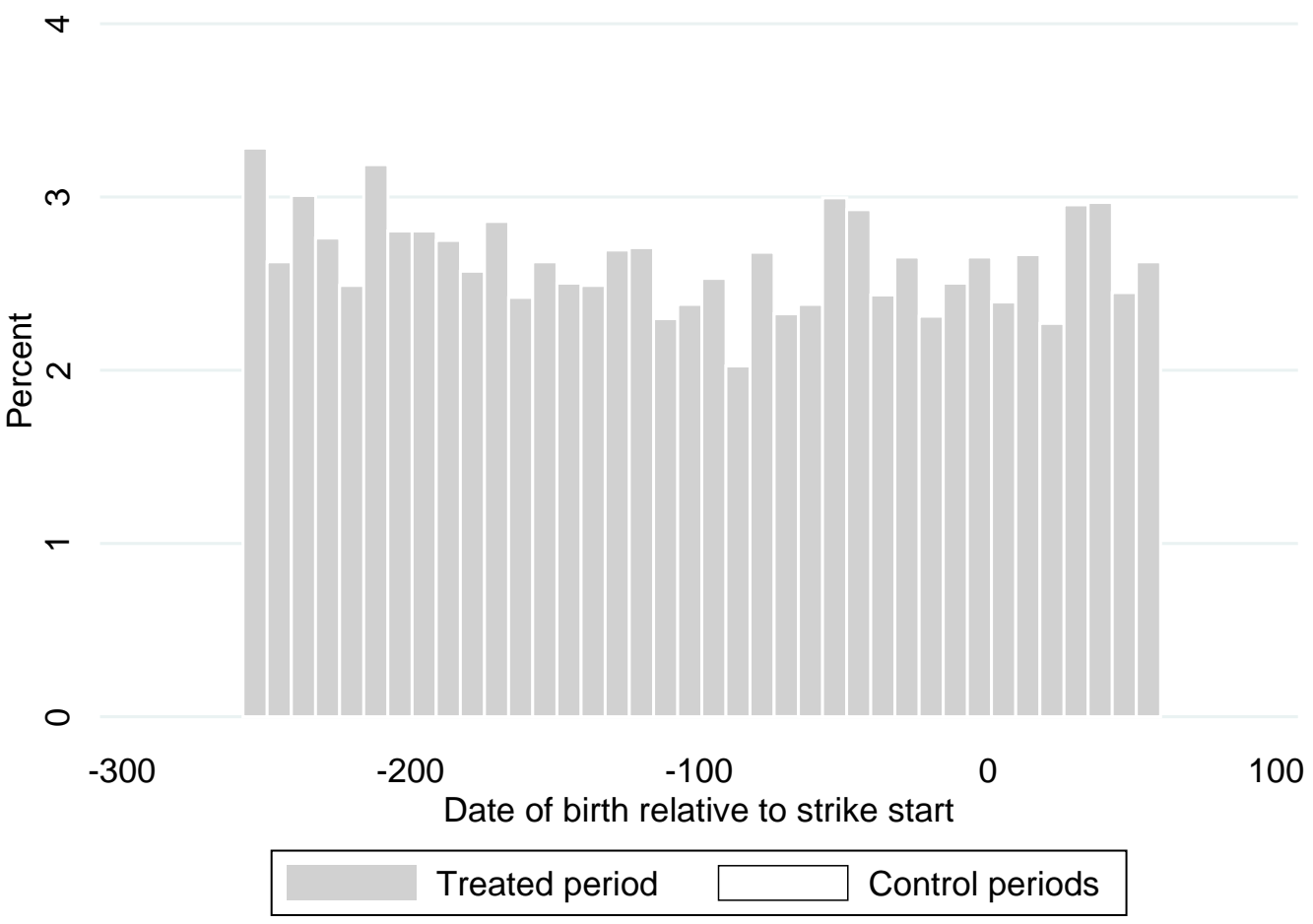

Fig. A4 Density of births

Notes: The figure show the density of births for 20 equally sized bins and a window 258 days prior to the beginning of the strike and 60 after the beginning of the strike. Grey bars are the strike exposed period and bars with black outline are children born on same dates the two followingyears. The vertical linesindicate the data period of our main analyses (treated period: September 18, 2007- April 15, 2008 and control periods: September 17, 2008 and 2009 - April 15, 2009 and 2010). 


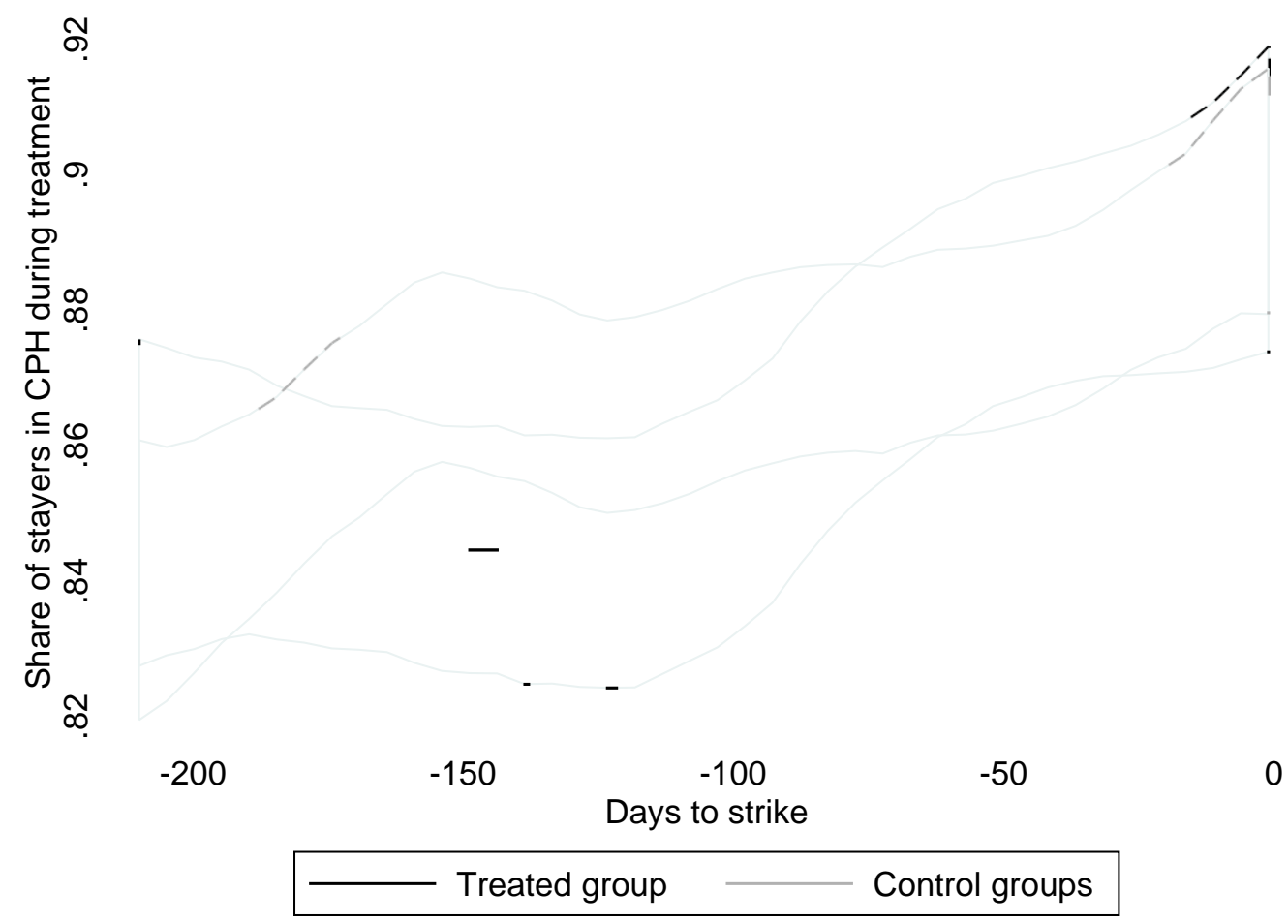

Fig. A5 Share of children observed as Copenhagen residents on January 1 in the treated and control periods

Notes: Se notes to Figure 3. The sample includes children who were born in Copenhagen in the treated period (September 18, 2007 - April 15, 2008) and control periods (September 17, 2008 and 2009 - April 15, 2009 and 2010). 


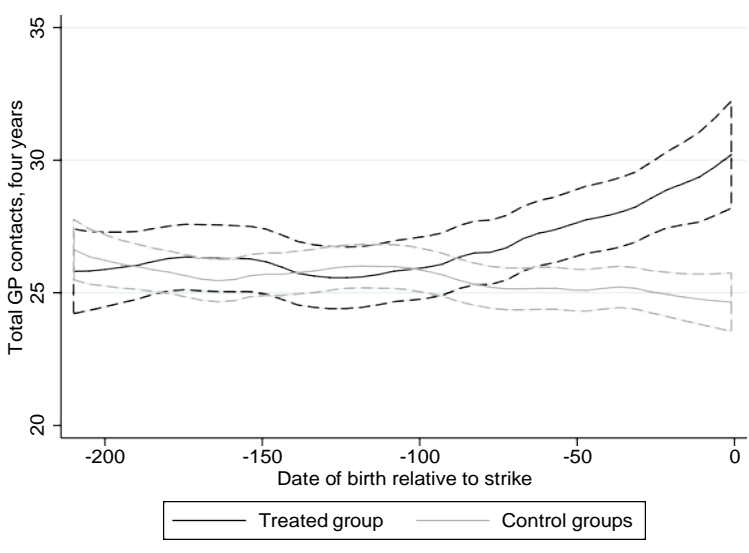

(a) Total GP contacts - Not Health educated

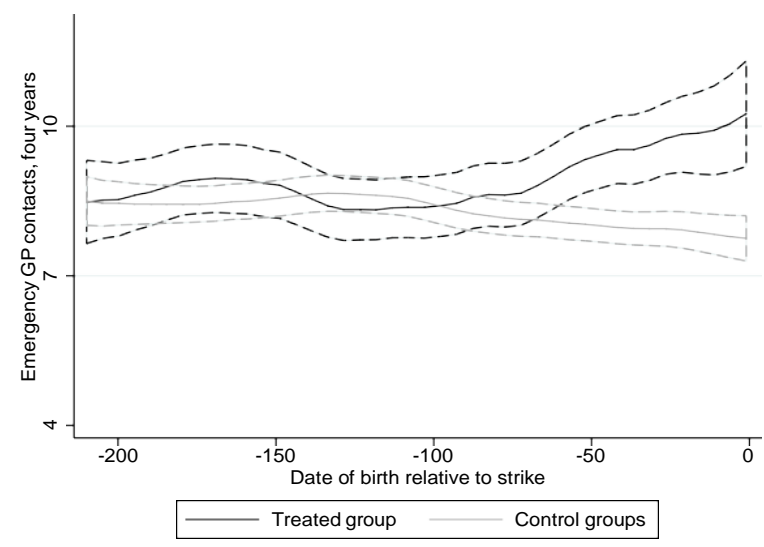

(c) Emergency GP contacts - Not health educated

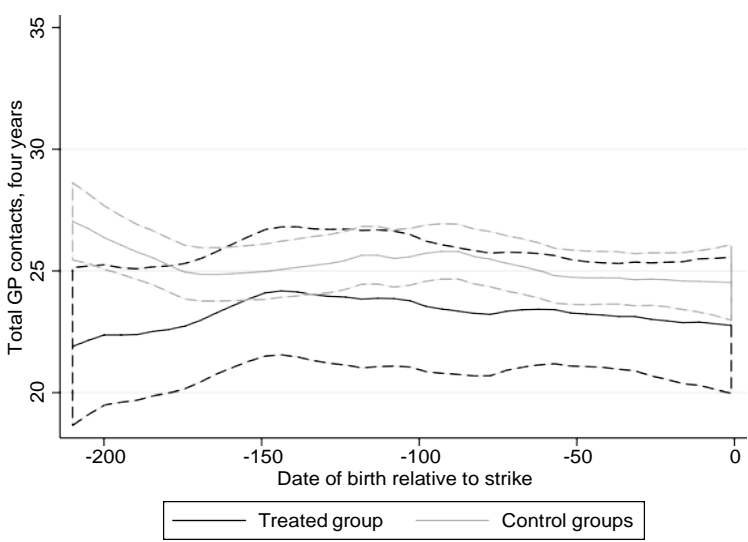

(b) Total GP contacts - Health educated

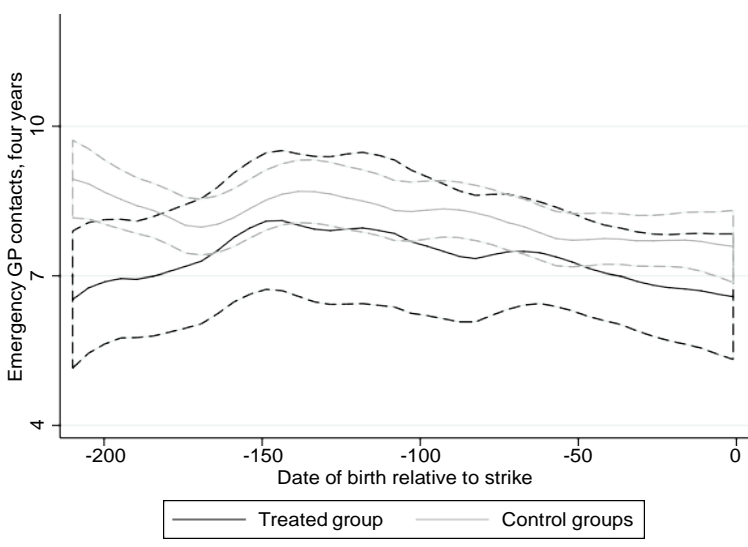

(d) Emergency GP contacts - Health educated

Fig. A6 Accumulated GP contacts at age four for children born in the treated period (September 18, 2007 - April 15, 2008) and the control periods (September 17, 2008 and 2009 - April 15, 2009 and 2010) and whether parents are educated in health Notes: The figure shows the relationship between date of birth and accumulated GP contacts at age four by parental background. See Figure 2 for further details. 
Table A1 Nurse home visiting in the municipality of Copenhagen

\begin{tabular}{ll}
\hline \hline Visit (and eligibility) & Timing \\
\hline $\begin{array}{l}\text { Universal visits } \\
\text { Initial visit (A) }\end{array}$ & 0-14 days after birth \\
2-months visit (B) & After two months of life \\
4-months visit (C) & After four months of life \\
8-months visit (D) & After eight months of life \\
& \\
Visits on parental demand & 30th week of gestation \\
Pregnancy visit & Immediately after birth. Home births and early discharge \\
$\begin{array}{l}\text { Maternity visit } \\
\text { 1,5-year visit }\end{array}$ & 1,5 years after birth \\
3-year visit & 3 years after birth \\
\multicolumn{2}{l}{ Targeted offer (at-risk families) } \\
Extra home visits & At discretion of nurses \\
\hline Notes: Source: Official guidelines for the Copenhagen NHV program.
\end{tabular}


Table A2 Balance testing: Parental covariates as outcome

\begin{tabular}{|c|c|c|c|c|c|c|c|c|}
\hline & $\begin{array}{l}\text { Prim. school, } \\
\text { mother } \\
\text { (1) }\end{array}$ & $\begin{array}{l}\text { Prim. school, } \\
\text { father } \\
(2)\end{array}$ & $\begin{array}{l}\text { Income, } \\
\text { mother } \\
\text { (3) }\end{array}$ & $\begin{array}{l}\text { Income, } \\
\text { father } \\
(4)\end{array}$ & $\begin{array}{l}\text { Onhnhitinn } \\
\text { (5) }\end{array}$ & $\begin{array}{l}\text { Anmmind } \\
\text { (6) }\end{array}$ & $\begin{array}{l}\text { Young } \\
\text { mother } \\
\text { (7) }\end{array}$ & $\begin{array}{c}\text { Young } \\
\text { father } \\
\text { (8) }\end{array}$ \\
\hline \multicolumn{9}{|l|}{ Days } \\
\hline 180-151 & $\begin{array}{l}-0.012 \\
(0.024)\end{array}$ & $\begin{array}{c}-0.023 \\
(0.024)\end{array}$ & $\begin{array}{r}-8.567 \\
(10.197)\end{array}$ & $\begin{array}{l}-123.961 \\
(140.780)\end{array}$ & $\begin{array}{c}0.034 \\
(0.031)\end{array}$ & $\begin{array}{l}-0.028 \\
(0.032)\end{array}$ & $\begin{array}{c}0.013 \\
(0.011)\end{array}$ & $\begin{array}{c}0.008 \\
(0.007)\end{array}$ \\
\hline $150-121$ & $\begin{array}{l}-0.021 \\
(0.024)\end{array}$ & $\begin{array}{c}-0.001 \\
(0.025)\end{array}$ & $\begin{array}{l}-1.703 \\
(9.999)\end{array}$ & $\begin{array}{l}-137.039 \\
(140.867)\end{array}$ & $\begin{array}{l}-0.008 \\
(0.031)\end{array}$ & $\begin{array}{c}-0.025 \\
(0.032)\end{array}$ & $\begin{array}{c}0.004 \\
(0.010)\end{array}$ & $\begin{array}{c}0.004 \\
(0.007)\end{array}$ \\
\hline $120-91$ & $\begin{array}{r}0.008 \\
(0.025)\end{array}$ & $\begin{array}{l}-0.039^{*} \\
(0.023)\end{array}$ & $\begin{array}{c}10.751 \\
(10.408)\end{array}$ & $\begin{array}{c}-113.671 \\
(141.624)\end{array}$ & $\begin{array}{c}0.045 \\
(0.031)\end{array}$ & $\begin{array}{c}-0.015 \\
(0.033)\end{array}$ & $\begin{array}{l}-0.012 \\
(0.011)\end{array}$ & $\begin{array}{l}-0.002 \\
(0.006)\end{array}$ \\
\hline $90-61$ & $\begin{array}{r}0.021 \\
(0.025)\end{array}$ & $\begin{array}{c}0.007 \\
(0.024)\end{array}$ & $\begin{array}{c}-1.872 \\
(10.817)\end{array}$ & $\begin{array}{c}-115.782 \\
(140.864)\end{array}$ & $\begin{array}{c}0.046 \\
(0.029)\end{array}$ & $\begin{array}{c}0.017 \\
(0.034)\end{array}$ & $\begin{array}{c}0.014 \\
(0.011)\end{array}$ & $\begin{array}{c}0.007 \\
(0.006)\end{array}$ \\
\hline $60-31$ & $\begin{array}{l}-0.034 \\
(0.024)\end{array}$ & $\begin{array}{c}-0.010 \\
(0.024)\end{array}$ & $\begin{array}{c}-2.525 \\
(10.205)\end{array}$ & $\begin{array}{l}-107.583 \\
(140.496)\end{array}$ & $\begin{array}{c}0.050^{*} \\
(0.029)\end{array}$ & $\begin{array}{l}-0.029 \\
(0.032)\end{array}$ & $\begin{array}{c}0.011 \\
(0.010)\end{array}$ & $\begin{array}{c}0.008 \\
(0.006)\end{array}$ \\
\hline $30-1$ & $\begin{array}{l}-0.014 \\
(0.024)\end{array}$ & $\begin{array}{l}-0.034 \\
(0.023)\end{array}$ & $\begin{array}{c}11.237 \\
(28.824)\end{array}$ & $\begin{array}{c}-86.723 \\
(140.922)\end{array}$ & $\begin{array}{c}0.034 \\
(0.029)\end{array}$ & $\begin{array}{l}-0.015 \\
(0.033)\end{array}$ & $\begin{array}{c}0.015 \\
(0.011)\end{array}$ & $\begin{array}{l}-0.003 \\
(0.006)\end{array}$ \\
\hline Obs. & 12568 & 12568 & 12568 & 12568 & 12568 & 12568 & 12568 & 12332 \\
\hline
\end{tabular}

Notes: Each column shows theestimatesfrom separateregressions. Thecoefficientsarefortheinteractions of 30-daybins anda strikeindicator. All regressionsincludeperiodand bin fixed effects. Thesampleincludeschildren who werebornin Copenhagen in the treated period (September 18, 2007 - April 15, 2008) and in control periods (September 17, 2008 and 2009 - April 15, 2009 and 2010). Robust standard errors in parentheses. ${ }^{* * *} p<0.01,{ }^{* *} p<0.05$ and $* p<0.10$. 
Table A3 Balance testing: Covariates at birth as outcome

\begin{tabular}{|c|c|c|c|c|c|c|c|c|}
\hline & $\begin{array}{l}\text { Hosp. nights } \\
\text { at birth } \\
\text { (1) }\end{array}$ & $\begin{array}{c}\text { Midwife } \\
\text { contacts } \\
(2)\end{array}$ & $\begin{array}{c}\text { C- } \\
\text { section } \\
(3)\end{array}$ & $\begin{array}{l}\text { Home } \\
\text { birth } \\
(4)\end{array}$ & $\begin{array}{c}\text { Preterm } \\
\text { birth } \\
\text { (5) }\end{array}$ & $\begin{array}{l}\text { Low birth } \\
\text { weight } \\
\text { (6) }\end{array}$ & $\begin{array}{c}\text { Head } \\
\text { size } \\
(7)\end{array}$ & $\begin{array}{c}\text { Female } \\
\text { child } \\
\text { (8) }\end{array}$ \\
\hline \multicolumn{9}{|l|}{ Days } \\
\hline 180-151 & $\begin{array}{l}-0.912 \\
(0.640)\end{array}$ & $\begin{array}{l}-0.018 \\
(0.110)\end{array}$ & $\begin{array}{l}-0.009 \\
(0.030)\end{array}$ & $\begin{array}{c}0.000 \\
(0.002)\end{array}$ & $\begin{array}{c}-0.003 \\
(0.018)\end{array}$ & $\begin{array}{l}-0.019 \\
(0.017)\end{array}$ & $\begin{array}{c}0.088 \\
(0.129)\end{array}$ & $\begin{array}{c}0.025 \\
(0.035)\end{array}$ \\
\hline $150-121$ & $\begin{array}{l}-0.308 \\
(0.636)\end{array}$ & $\begin{array}{c}0.105 \\
(0.108)\end{array}$ & $\begin{array}{l}-0.005 \\
(0.029)\end{array}$ & $\begin{array}{c}0.003 \\
(0.004)\end{array}$ & $\begin{array}{c}-0.034^{* *} \\
(0.017)\end{array}$ & $\begin{array}{l}-0.019 \\
(0.016)\end{array}$ & $\begin{array}{c}0.018 \\
(0.137)\end{array}$ & $\begin{array}{l}0.060^{*} \\
(0.035)\end{array}$ \\
\hline $120-91$ & $\begin{array}{c}-0.716 \\
(0.716)\end{array}$ & $\begin{array}{c}0.023 \\
(0.116)\end{array}$ & $\begin{array}{l}-0.003 \\
(0.030)\end{array}$ & $\begin{array}{l}-0.002 \\
(0.002)\end{array}$ & $\begin{array}{l}-0.033^{*} \\
(0.018)\end{array}$ & $\begin{array}{c}-0.040^{* *} \\
(0.016)\end{array}$ & $\begin{array}{l}-0.070 \\
(0.129)\end{array}$ & $\begin{array}{c}0.038 \\
(0.036)\end{array}$ \\
\hline $90-61$ & $\begin{array}{l}-0.703 \\
(0.624)\end{array}$ & $\begin{array}{l}-0.004 \\
(0.118)\end{array}$ & $\begin{array}{c}0.010 \\
(0.030)\end{array}$ & $\begin{array}{l}-0.000 \\
(0.004)\end{array}$ & $\begin{array}{l}-0.023 \\
(0.017)\end{array}$ & $\begin{array}{l}-0.021 \\
(0.015)\end{array}$ & $\begin{array}{l}-0.039 \\
(0.123)\end{array}$ & $\begin{array}{c}0.047 \\
(0.036)\end{array}$ \\
\hline $60-31$ & $\begin{array}{l}-0.675 \\
(0.644)\end{array}$ & $\begin{array}{c}0.090 \\
(0.116)\end{array}$ & $\begin{array}{l}-0.021 \\
(0.028)\end{array}$ & $\begin{array}{c}0.001 \\
(0.003)\end{array}$ & $\begin{array}{l}-0.019 \\
(0.017)\end{array}$ & $\begin{array}{l}-0.011 \\
(0.016)\end{array}$ & $\begin{array}{c}0.027 \\
(0.127)\end{array}$ & $\begin{array}{l}0.071^{* *} \\
(0.035)\end{array}$ \\
\hline $30-1$ & $\begin{array}{l}-0.627 \\
(0.638)\end{array}$ & $\begin{array}{l}-0.083 \\
(0.103)\end{array}$ & $\begin{array}{l}-0.001 \\
(0.029)\end{array}$ & $\begin{array}{l}-0.003 \\
(0.003)\end{array}$ & $\begin{array}{c}-0.037^{* *} \\
(0.016)\end{array}$ & $\begin{array}{l}-0.022 \\
(0.015)\end{array}$ & $\begin{array}{l}0.249^{*} \\
(0.137)\end{array}$ & $\begin{array}{c}0.058 \\
(0.035)\end{array}$ \\
\hline Obs. & 12537 & 12409 & 12568 & 12568 & 12518 & 12515 & 12332 & 12568 \\
\hline
\end{tabular}

Notes: See notes for Table A2. ${ }^{* * *} p<0.01,{ }^{* *} p<0.05$ and ${ }^{*} p<0.10$. 
Table A4 Variable means, population of children born in Copenhagen and Denmark.

\begin{tabular}{|c|c|c|c|c|}
\hline & Denmark Excl. CPH & & $\mathrm{CPH}$ & \\
\hline & Mean & Obs. & Mean & Obs. \\
\hline Cohabitation & 0.86 & 115578 & 0.78 & 17949 \\
\hline Married & 0.47 & 115302 & 0.39 & 17917 \\
\hline Prim. school, mother & 0.18 & 111553 & 0.13 & 17054 \\
\hline Uni. degree, mother & 0.13 & 111553 & 0.33 & 17054 \\
\hline Student, mother & 0.03 & 114562 & 0.05 & 17927 \\
\hline Employed, mother & 0.81 & 114562 & 0.79 & 17927 \\
\hline Prim. school, father & 0.19 & 110697 & 0.15 & 16561 \\
\hline Uni. degree, father & 0.13 & 110697 & 0.33 & 16561 \\
\hline Student, father & 0.01 & 113425 & 0.03 & 17334 \\
\hline Employed, father & 0.90 & 113425 & 0.86 & 17334 \\
\hline Danish, mother & 0.86 & 116827 & 0.76 & 18302 \\
\hline Danish, father & 0.87 & 115578 & 0.75 & 17949 \\
\hline Young mother & 0.05 & 116827 & 0.02 & 18302 \\
\hline Young father & 0.02 & 115578 & 0.01 & 17949 \\
\hline Income, mother & 255.79 & 114550 & 267.55 & 17926 \\
\hline Income, father & 367.66 & 112391 & 361.10 & 17179 \\
\hline Length child & 51.72 & 113575 & 51.66 & 17849 \\
\hline Low birth weight & 0.05 & 114518 & 0.05 & 18021 \\
\hline Preterm birth & 0.07 & 114637 & 0.06 & 18020 \\
\hline Head size & 34.94 & 112024 & 34.79 & 17746 \\
\hline First time mothers & 0.43 & 112743 & 0.62 & 17967 \\
\hline Multiple birth & 0.04 & 116827 & 0.04 & 18302 \\
\hline C-section & 0.22 & 116827 & 0.22 & 18302 \\
\hline No. of hosptial nights at birth, child & 3.83 & 114819 & 3.83 & 18070 \\
\hline Home birth & 0.01 & 116827 & 0.01 & 18302 \\
\hline Midwife visits & 4.80 & 111599 & 4.76 & 17814 \\
\hline Smoking status, Mother & 0.17 & 114653 & 0.09 & 18020 \\
\hline BMI mom & 24.46 & 107368 & 22.92 & 17424 \\
\hline Heigth mom & 167.98 & 108542 & 167.88 & 17557 \\
\hline
\end{tabular}

Notes: The Copenhagen sample includes all children born in Copenhagen in the periods: September 18, 2007- April 15, 2008 and September 17, 2008 and 2009-April 15, 2009 and 2010. The Denmark samples includes all children born in the same periods in Denmark, excluding Copenhagen. 
Table A5 Additional child health outcomes: Effects of strike exposure on child hospitalization and outpatient contacts

\begin{tabular}{|c|c|c|c|c|c|c|}
\hline & $\begin{array}{c}\text { (1) } \\
\text { Hospital adm. } \\
\text { 1st year }\end{array}$ & $\begin{array}{c}(2) \\
\text { Hospital adm. } \\
\text { 2nd year }\end{array}$ & $\begin{array}{c}\text { (3) } \\
\text { Hospital adm. } \\
\text { 3-4 years }\end{array}$ & $\begin{array}{l}\text { (4) } \\
\text { Outpat. cont. } \\
\text { 1st year }\end{array}$ & $\begin{array}{l}\text { (5) } \\
\text { Outpat. cont. } \\
\text { 2nd year }\end{array}$ & $\begin{array}{c}\text { (6) } \\
\text { Outpat. cont. } \\
\text { 3-4 years }\end{array}$ \\
\hline \multicolumn{7}{|l|}{ Days } \\
\hline 180-151 & $\begin{array}{r}0.008 \\
(0.030)\end{array}$ & $\begin{array}{c}0.007 \\
(0.027)\end{array}$ & $\begin{array}{c}0.032 \\
(0.028)\end{array}$ & $\begin{array}{c}0.009 \\
(0.035)\end{array}$ & $\begin{array}{c}-0.029 \\
(0.033)\end{array}$ & $\begin{array}{c}0.024 \\
(0.036)\end{array}$ \\
\hline $150-121$ & $\begin{array}{l}-0.032 \\
(0.030)\end{array}$ & $\begin{array}{c}-0.009 \\
(0.028)\end{array}$ & $\begin{array}{c}-0.015 \\
(0.028)\end{array}$ & $\begin{array}{c}0.038 \\
(0.035)\end{array}$ & $\begin{array}{c}-0.026 \\
(0.032)\end{array}$ & $\begin{array}{c}0.035 \\
(0.036)\end{array}$ \\
\hline $120-91$ & $\begin{array}{r}0.001 \\
(0.031)\end{array}$ & $\begin{array}{c}0.015 \\
(0.028)\end{array}$ & $\begin{array}{c}-0.032 \\
(0.028)\end{array}$ & $\begin{array}{c}-0.012 \\
(0.035)\end{array}$ & $\begin{array}{r}-0.021 \\
(0.033)\end{array}$ & $\begin{array}{c}-0.051 \\
(0.036)\end{array}$ \\
\hline $90-61$ & $\begin{array}{r}0.037 \\
(0.031)\end{array}$ & $\begin{array}{c}0.024 \\
(0.029)\end{array}$ & $\begin{array}{c}-0.015 \\
(0.028)\end{array}$ & $\begin{array}{c}-0.003 \\
(0.035)\end{array}$ & $\begin{array}{c}-0.032 \\
(0.033)\end{array}$ & $\begin{array}{c}-0.029 \\
(0.036)\end{array}$ \\
\hline $60-31$ & $\begin{array}{r}0.004 \\
(0.030)\end{array}$ & $\begin{array}{l}0.067^{* *} \\
(0.028)\end{array}$ & $\begin{array}{c}0.013 \\
(0.028)\end{array}$ & $\begin{array}{c}-0.027 \\
(0.035)\end{array}$ & $\begin{array}{c}-0.005 \\
(0.032)\end{array}$ & $\begin{array}{c}0.000 \\
(0.035)\end{array}$ \\
\hline $30-1$ & $\begin{array}{r}0.036 \\
(0.030)\end{array}$ & $\begin{array}{c}0.078^{* * *} \\
(0.029)\end{array}$ & $\begin{array}{c}0.007 \\
(0.028)\end{array}$ & $\begin{array}{l}-0.060 * \\
(0.034)\end{array}$ & $\begin{array}{c}0.025 \\
(0.033)\end{array}$ & $\begin{array}{c}-0.002 \\
(0.036)\end{array}$ \\
\hline Control group mean & 0.27 & 0.19 & 0.18 & 0.39 & 0.27 & 0.41 \\
\hline Obs. & 12078 & 11982 & 11709 & 12078 & 11982 & 11709 \\
\hline
\end{tabular}

Notes: See notes to table 3. Robust standard errors in parentheses. ${ }^{* *} p<0.01,{ }^{* *} p<0.05$ and ${ }^{*} p<0.10$. 
Table A6 Heterogeneity: Effects of strike exposure on total GP contacts by parental education and parity

\begin{tabular}{lcccccccc}
\hline & \multicolumn{2}{c}{ Not health educ. } & \multicolumn{3}{c}{ Health educ. } & \multicolumn{2}{c}{ Higher parity } & \multicolumn{3}{c}{ First-borns } \\
& $\begin{array}{c}\text { Total GP } \\
\text { 1st year } \\
(1)\end{array}$ & $\begin{array}{c}\text { Total GP } \\
2-4 \text { years } \\
(2)\end{array}$ & $\begin{array}{c}\text { Total GP } \\
\text { 1st year } \\
(3)\end{array}$ & $\begin{array}{c}\text { Total GP } \\
2-4 \text { years } \\
(4)\end{array}$ & $\begin{array}{c}\text { Total GP } \\
\text { 1st year } \\
(5)\end{array}$ & $\begin{array}{c}\text { Total GP } \\
2-4 \text { years } \\
(6)\end{array}$ & $\begin{array}{c}\text { Total GP } \\
\text { 1st year } \\
(7)\end{array}$ & $\begin{array}{c}\text { Total GP } \\
2-4 \text { years } \\
(8)\end{array}$ \\
\hline Days & & & & & & & & \\
$180-151$ & 0.478 & 0.737 & 0.723 & 2.362 & 0.564 & -1.207 & 0.478 & 2.134 \\
& $(0.569)$ & $(1.081)$ & $(1.241)$ & $(2.333)$ & $(0.745)$ & $(1.489)$ & $(0.700)$ & $(1.317)$ \\
$150-121$ & 0.153 & 0.921 & 1.313 & 1.096 & 0.198 & -1.147 & 0.381 & $2.225^{*}$ \\
& $(0.554)$ & $(1.046)$ & $(1.477)$ & $(2.859)$ & $(0.801)$ & $(1.490)$ & $(0.679)$ & $(1.307)$ \\
$120-91$ & -0.078 & -0.389 & -1.318 & 0.543 & -0.482 & -0.710 & 0.020 & 0.509 \\
& $(0.570)$ & $(1.015)$ & $(1.358)$ & $(2.522)$ & $(0.807)$ & $(1.498)$ & $(0.693)$ & $(1.236)$ \\
$90-61$ & 0.754 & 1.594 & 0.459 & 0.318 & 0.520 & 0.462 & 0.842 & 2.002 \\
& $(0.601)$ & $(1.040)$ & $(1.387)$ & $(2.619)$ & $(0.754)$ & $(1.433)$ & $(0.766)$ & $(1.307)$ \\
$60-31$ & 0.262 & $2.347^{* *}$ & 0.517 & 2.244 & 0.339 & 1.304 & 0.397 & $3.214^{* *}$ \\
& $(0.579)$ & $(1.051)$ & $(1.267)$ & $(2.410)$ & $(0.774)$ & $(1.415)$ & $(0.716)$ & $(1.318)$ \\
$30-1$ & $1.924^{* * *}$ & $3.484^{* * *}$ & 1.375 & 1.234 & $2.319^{* * *}$ & 1.574 & $1.511^{* *}$ & $3.873^{* * *}$ \\
& $(0.611)$ & $(1.101)$ & $(1.326)$ & $(2.159)$ & $(0.831)$ & $(1.462)$ & $(0.738)$ & $(1.341)$ \\
\hline Control group mean & 4.72 & 20.95 & 3.52 & 18.75 & 4.07 & 17.88 & 4.91 & 22.59 \\
Observations & 10445 & 10114 & 1633 & 1584 & 4750 & 4605 & 7328 & 7093
\end{tabular}

Notes: See notes for Table 3. Column labels indicate the relevant subgroup and outcome variable studied. Columns (1)-(4) split the sample by parental educational background in a health-related field (either one of the parents are educated as a doctor, midwife, nurse or pedagogue). Columns (5)-(8) split the sampleby parity of the child. Robust standard errors in parentheses. ${ }^{* * *} p<0.01,{ }^{* *} p<0.05$ and ${ }^{*} p<0.10$. 
Table A7 Heterogeneity: Effects of strike exposure on total GP contacts, interacted model

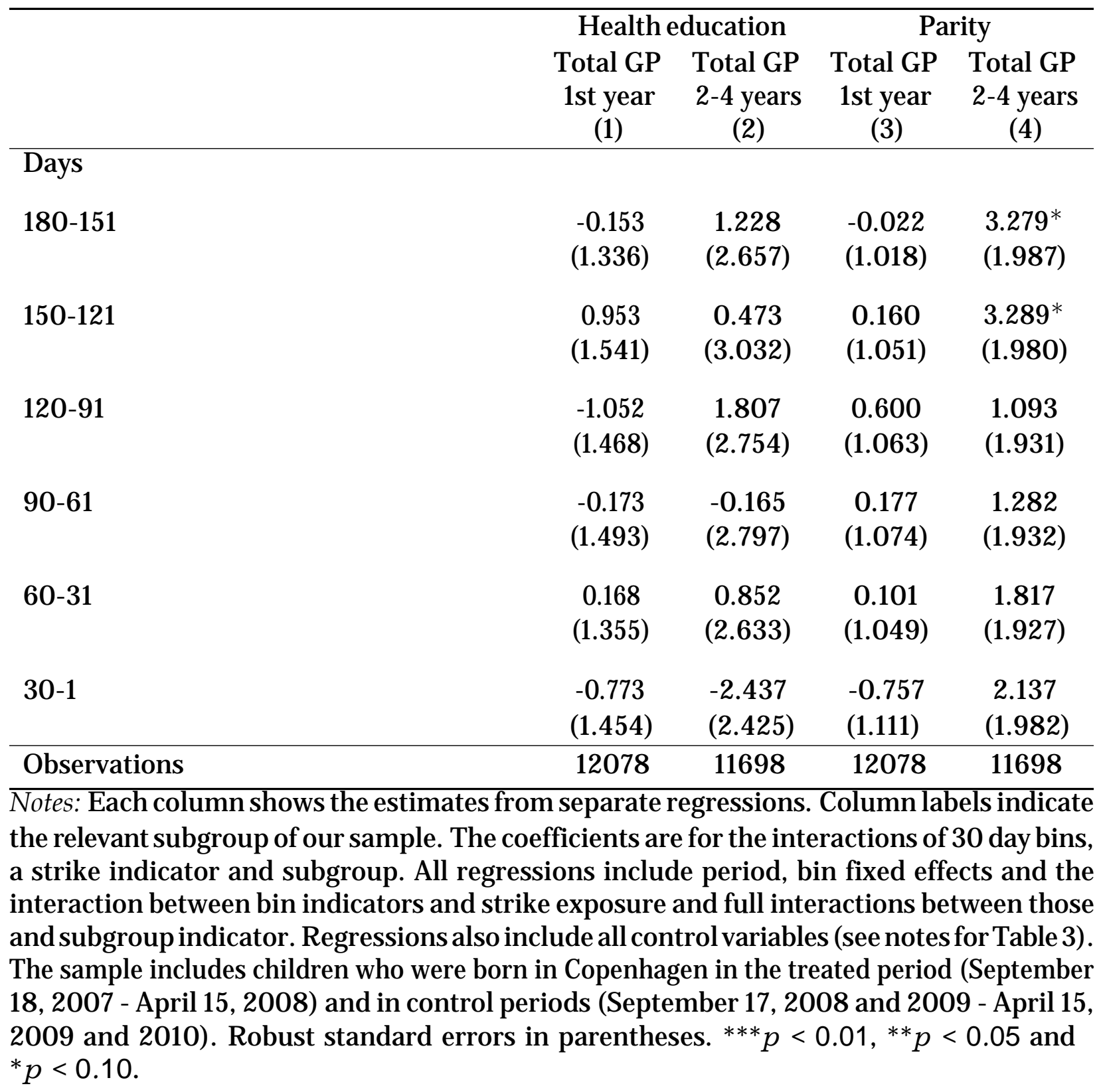


Table A8 Heterogeneity: Effects of strike exposure on total GP contacts at age four

\begin{tabular}{|c|c|c|c|c|c|c|c|c|}
\hline & \multicolumn{2}{|c|}{ Gender } & \multicolumn{2}{|c|}{ Initial health } & \multicolumn{2}{|c|}{ SES } & \multicolumn{2}{|c|}{ Smoking, mother } \\
\hline & $\begin{array}{l}\text { Boys } \\
\text { (1) }\end{array}$ & $\begin{array}{l}\text { Girls } \\
(2)\end{array}$ & $\begin{array}{l}\text { Not poor } \\
\text { (3) }\end{array}$ & $\begin{array}{l}\text { poor } \\
(4)\end{array}$ & $\begin{array}{l}\text { High } \\
\text { (5) }\end{array}$ & $\begin{array}{l}\text { Low } \\
\text { (6) }\end{array}$ & $\begin{array}{l}\text { No } \\
\text { (7) }\end{array}$ & $\begin{array}{l}\text { Yes } \\
(8)\end{array}$ \\
\hline \multicolumn{9}{|l|}{ Days } \\
\hline $180-151$ & $\begin{array}{l}3.288^{*} \\
(1.802)\end{array}$ & $\begin{array}{c}-0.946 \\
(1.846)\end{array}$ & $\begin{array}{r}1.094 \\
(1.366)\end{array}$ & $\begin{array}{c}5.329 \\
(3.803)\end{array}$ & $\begin{array}{c}2.289 \\
(1.424)\end{array}$ & $\begin{array}{l}-0.897 \\
(2.733)\end{array}$ & $\begin{array}{c}1.038 \\
(1.326)\end{array}$ & $\begin{array}{c}4.902 \\
(5.182)\end{array}$ \\
\hline $150-121$ & $\begin{array}{r}0.263 \\
(1.753)\end{array}$ & $\begin{array}{c}2.525 \\
(1.870)\end{array}$ & $\begin{array}{c}1.410 \\
(1.333)\end{array}$ & $\begin{array}{c}1.095 \\
(4.672)\end{array}$ & $\begin{array}{l}3.238^{* *} \\
(1.442)\end{array}$ & $\begin{array}{l}-3.478 \\
(2.633)\end{array}$ & $\begin{array}{c}1.211 \\
(1.326)\end{array}$ & $\begin{array}{c}3.083 \\
(4.676)\end{array}$ \\
\hline $120-91$ & $\begin{array}{r}0.596 \\
(1.770)\end{array}$ & $\begin{array}{l}-1.493 \\
(1.749)\end{array}$ & $\begin{array}{l}-0.919 \\
(1.307)\end{array}$ & $\begin{array}{l}8.509^{* *} \\
(4.152)\end{array}$ & $\begin{array}{c}1.232 \\
(1.389)\end{array}$ & $\begin{array}{l}-4.064 \\
(2.615)\end{array}$ & $\begin{array}{l}-0.892 \\
(1.284)\end{array}$ & $\begin{array}{c}4.944 \\
(4.908)\end{array}$ \\
\hline $90-61$ & $\begin{array}{l}3.727^{* *} \\
(1.837)\end{array}$ & $\begin{array}{c}0.616 \\
(1.807)\end{array}$ & $\begin{array}{l}2.263^{*} \\
(1.358)\end{array}$ & $\begin{array}{c}1.520 \\
(4.148)\end{array}$ & $\begin{array}{l}3.125^{* *} \\
(1.484)\end{array}$ & $\begin{array}{c}-0.242 \\
(2.569)\end{array}$ & $\begin{array}{c}1.846 \\
(1.360)\end{array}$ & $\begin{array}{c}5.659 \\
(4.350)\end{array}$ \\
\hline $60-31$ & $\begin{array}{l}3.580^{*} \\
(1.918)\end{array}$ & $\begin{array}{c}1.799 \\
(1.742)\end{array}$ & $\begin{array}{l}1.911 \\
(1.330)\end{array}$ & $\begin{array}{c}13.082^{* *} \\
(5.538)\end{array}$ & $\begin{array}{c}3.869^{* * *} \\
(1.443)\end{array}$ & $\begin{array}{c}0.267 \\
(2.682)\end{array}$ & $\begin{array}{c}2.224 \\
(1.363)\end{array}$ & $\begin{array}{l}8.323^{* *} \\
(4.109)\end{array}$ \\
\hline $30-1$ & $\begin{array}{c}6.457^{* * *} \\
(1.871)\end{array}$ & $\begin{array}{c}2.617 \\
(1.857)\end{array}$ & $\begin{array}{c}4.336^{* * *} \\
(1.379)\end{array}$ & $\begin{array}{c}8.088 \\
(5.189)\end{array}$ & $\begin{array}{c}5.001^{* * *} \\
(1.447)\end{array}$ & $\begin{array}{c}4.105 \\
(2.914)\end{array}$ & $\begin{array}{c}4.344^{* * *} \\
(1.374)\end{array}$ & $\begin{array}{l}8.438^{*} \\
(4.834)\end{array}$ \\
\hline $\begin{array}{l}\text { Control } \\
\text { group } \\
\text { mean }\end{array}$ & 26.35 & 24.00 & 25.17 & 26.97 & 24.68 & 26.51 & 25.05 & 27.99 \\
\hline Observatic & 6085 & 5644 & 10803 & 926 & 8381 & 3348 & 10681 & 1048 \\
\hline \multicolumn{9}{|c|}{$\begin{array}{l}\text { Notes: See notes to Table } 3 \text { and A6. Columns (1)-(2) split the sample by child gender. } \\
\text { Columns (3)-(4) split the sample by initial health (low birth weight, premature birth or } \\
\text { complications during birth). Columns (5)-(6) split the sample by parental socio-economic } \\
\text { status (SES). A low SES background is a child born to parents with either incomes in the } \\
\text { bottom decile, below age } 21 \text { at birth or with only primary schooling. Columns ( } 7 \text { )-( } 8 \text { ) split } \\
\text { the sample by whether the mother smoked during pregnancy. Robust standard errors in } \\
\text { parentheses. }{ }^{* * *} p<0.01,{ }^{* *} p<0.05 \text { and }{ }^{*} p<0.10 \text {. }\end{array}$} \\
\hline
\end{tabular}


Table A9 Parental investments: Effects of strike exposure on participation in preventive health checks

\begin{tabular}{|c|c|c|c|c|c|c|}
\hline & $\begin{array}{c}(1) \\
\text { Prev. care, } \\
5 \text { weeks }\end{array}$ & $\begin{array}{c}(2) \\
\text { Prev. care, } \\
5 \text { months }\end{array}$ & $\begin{array}{c}(3) \\
\text { Prev. care, } \\
12 \text { months }\end{array}$ & $\begin{array}{c}(4) \\
\text { Prev. care, } \\
2 \text { years }\end{array}$ & $\begin{array}{c}(5) \\
\text { Prev. care, } \\
3 \text { years }\end{array}$ & $\begin{array}{c}(6) \\
\text { Prev. care, } \\
4 \text { years }\end{array}$ \\
\hline \multicolumn{7}{|l|}{ Days } \\
\hline 180-151 & $\begin{array}{c}0.002 \\
(0.022)\end{array}$ & $\begin{array}{c}0.005 \\
(0.019)\end{array}$ & $\begin{array}{c}0.005 \\
(0.018)\end{array}$ & $\begin{array}{c}0.065^{*} \\
(0.034)\end{array}$ & $\begin{array}{c}0.057 \\
(0.035)\end{array}$ & $\begin{array}{c}0.034 \\
(0.030)\end{array}$ \\
\hline $150-121$ & $\begin{array}{c}0.007 \\
(0.021)\end{array}$ & $\begin{array}{l}-0.008 \\
(0.018)\end{array}$ & $\begin{array}{c}0.011 \\
(0.019)\end{array}$ & $\begin{array}{c}0.043 \\
(0.034)\end{array}$ & $\begin{array}{c}0.036 \\
(0.035)\end{array}$ & $\begin{array}{c}0.005 \\
(0.031)\end{array}$ \\
\hline 120-91 & $\begin{array}{l}-0.009 \\
(0.022)\end{array}$ & $\begin{array}{c}-0.008 \\
(0.019)\end{array}$ & $\begin{array}{l}-0.009 \\
(0.019)\end{array}$ & $\begin{array}{c}0.010 \\
(0.035)\end{array}$ & $\begin{array}{c}-0.034 \\
(0.036)\end{array}$ & $\begin{array}{c}-0.017 \\
(0.031)\end{array}$ \\
\hline $90-61$ & $\begin{array}{c}0.015 \\
(0.021)\end{array}$ & $\begin{array}{c}0.004 \\
(0.020)\end{array}$ & $\begin{array}{c}0.012 \\
(0.018)\end{array}$ & $\begin{array}{c}0.107^{* * *} \\
(0.034)\end{array}$ & $\begin{array}{c}0.099 * * * \\
(0.036)\end{array}$ & $\begin{array}{c}0.039 \\
(0.031)\end{array}$ \\
\hline $60-31$ & $\begin{array}{c}0.017 \\
(0.021)\end{array}$ & $\begin{array}{c}-0.014 \\
(0.019)\end{array}$ & $\begin{array}{c}0.029 * \\
(0.018)\end{array}$ & $\begin{array}{c}0.034 \\
(0.033)\end{array}$ & $\begin{array}{c}0.090^{* * *} \\
(0.034)\end{array}$ & $\begin{array}{c}0.018 \\
(0.030)\end{array}$ \\
\hline 30-1 & $\begin{array}{c}0.012 \\
(0.020)\end{array}$ & $\begin{array}{c}-0.000 \\
(0.019)\end{array}$ & $\begin{array}{c}0.017 \\
(0.018)\end{array}$ & $\begin{array}{c}0.056 \\
(0.034)\end{array}$ & $\begin{array}{l}0.083^{* *} \\
(0.035)\end{array}$ & $\begin{array}{c}0.037 \\
(0.030)\end{array}$ \\
\hline $\begin{array}{l}\text { Control } \\
\text { group } \\
\text { mean } \\
\text { Obs. }\end{array}$ & 12078 & 12078 & 12078 & 11982 & 11832 & 11729 \\
\hline
\end{tabular}


Table A10 Parental investments: Effects of strike exposure on participation in the infant vaccination program

\begin{tabular}{lccc}
\hline & $(1)$ & $(2)$ & $(3)$ \\
& Vacc., & $\begin{array}{c}\text { Vacc., } \\
\text { Vacc., } \\
\text { 1st round }\end{array}$ & $\begin{array}{c}\text { 2nd round } \\
\text { 3rd round }\end{array}$ \\
\hline Days & & & \\
$180-151$ & -0.025 & -0.015 & $-0.036^{*}$ \\
& $(0.025)$ & $(0.023)$ & $(0.022)$ \\
$150-121$ & -0.005 & -0.032 & $-0.039^{*}$ \\
& $(0.024)$ & $(0.023)$ & $(0.022)$ \\
$120-91$ & 0.013 & -0.009 & $-0.045^{* *}$ \\
& $(0.024)$ & $(0.023)$ & $(0.023)$ \\
90-61 & -0.011 & -0.010 & -0.021 \\
& $(0.025)$ & $(0.024)$ & $(0.023)$ \\
60-31 & -0.018 & -0.026 & 0.017 \\
& $(0.024)$ & $(0.023)$ & $(0.022)$ \\
30-1 & 0.006 & 0.001 & -0.034 \\
Control group mean & $(0.024)$ & $(0.023)$ & $(0.022)$ \\
\hline Obs. & 0.90 & 0.91 & 0.91 \\
\end{tabular}

Notes: See notes for Table3. Outcomes are indicators for participation in each vaccination round scheduled within thefirstyear of achild's life. Robuststandard errorsin parentheses. ${ }^{* * *} p<0.01,{ }^{* *} p<0.05$ and ${ }^{*} p<0.10$. 
Table A11 Robustness: Effects of strike exposure on child GP contacts without pre-treatment covariates

\begin{tabular}{|c|c|c|c|c|c|c|c|c|c|}
\hline & $\begin{array}{c}(1) \\
\text { Total GP } \\
\text { 1st year }\end{array}$ & $\begin{array}{c}(2) \\
\text { Total GP } \\
\text { 2nd year }\end{array}$ & $\begin{array}{c}(3) \\
\text { Total GP } \\
\text { 3-4 years }\end{array}$ & $\begin{array}{c}(4) \\
\text { Ordin. GP } \\
\text { 1st year }\end{array}$ & $\begin{array}{c}\text { (5) } \\
\text { Ordin. GP } \\
\text { 2nd year }\end{array}$ & $\begin{array}{c}\text { (6) } \\
\text { Ordin. GP } \\
\text { 3-4 years }\end{array}$ & $\begin{array}{c}\text { (7) } \\
\text { Emerg. GP } \\
\text { 1st year }\end{array}$ & $\begin{array}{c}(8) \\
\text { Emerg. GP } \\
\text { 2nd year }\end{array}$ & $\begin{array}{c}\text { (9) } \\
\text { Emerg. GP } \\
3-4 \text { years }\end{array}$ \\
\hline \multicolumn{10}{|l|}{ Days } \\
\hline $180-151$ & $\begin{array}{c}0.470 \\
(0.513)\end{array}$ & $\begin{array}{c}0.025 \\
(0.513)\end{array}$ & $\begin{array}{c}0.556 \\
(0.595)\end{array}$ & $\begin{array}{c}0.166 \\
(0.344)\end{array}$ & $\begin{array}{c}-0.211 \\
(0.318)\end{array}$ & $\begin{array}{c}0.359 \\
(0.387)\end{array}$ & $\begin{array}{c}0.304 \\
(0.221)\end{array}$ & $\begin{array}{c}0.236 \\
(0.296)\end{array}$ & $\begin{array}{c}0.197 \\
(0.313)\end{array}$ \\
\hline $150-121$ & $\begin{array}{c}0.312 \\
(0.514)\end{array}$ & $\begin{array}{c}0.305 \\
(0.505)\end{array}$ & $\begin{array}{c}0.505 \\
(0.598)\end{array}$ & $\begin{array}{c}0.174 \\
(0.339)\end{array}$ & $\begin{array}{c}0.142 \\
(0.317)\end{array}$ & $\begin{array}{c}0.428 \\
(0.385)\end{array}$ & $\begin{array}{c}0.138 \\
(0.228)\end{array}$ & $\begin{array}{c}0.163 \\
(0.289)\end{array}$ & $\begin{array}{c}0.077 \\
(0.313)\end{array}$ \\
\hline $120-91$ & $\begin{array}{l}-0.294 \\
(0.518)\end{array}$ & $\begin{array}{c}-0.334 \\
(0.486)\end{array}$ & $\begin{array}{l}-0.248 \\
(0.563)\end{array}$ & $\begin{array}{l}-0.272 \\
(0.348)\end{array}$ & $\begin{array}{l}-0.053 \\
(0.305)\end{array}$ & $\begin{array}{c}0.036 \\
(0.378)\end{array}$ & $\begin{array}{l}-0.022 \\
(0.218)\end{array}$ & $\begin{array}{l}-0.281 \\
(0.283)\end{array}$ & $\begin{array}{l}-0.284 \\
(0.295)\end{array}$ \\
\hline $90-61$ & $\begin{array}{c}0.808 \\
(0.545)\end{array}$ & $\begin{array}{c}0.763 \\
(0.510)\end{array}$ & $\begin{array}{l}1.054^{*} \\
(0.581)\end{array}$ & $\begin{array}{c}0.370 \\
(0.373)\end{array}$ & $\begin{array}{c}0.469 \\
(0.327)\end{array}$ & $\begin{array}{c}0.687^{*} \\
(0.387)\end{array}$ & $\begin{array}{l}0.438^{* *} \\
(0.223)\end{array}$ & $\begin{array}{c}0.294 \\
(0.284)\end{array}$ & $\begin{array}{c}0.366 \\
(0.305)\end{array}$ \\
\hline $60-31$ & $\begin{array}{c}0.268 \\
(0.520)\end{array}$ & $\begin{array}{c}1.571^{* * *} \\
(0.501)\end{array}$ & $\begin{array}{c}0.400 \\
(0.573)\end{array}$ & $\begin{array}{c}0.068 \\
(0.346)\end{array}$ & $\begin{array}{c}0.896^{* * *} \\
(0.317)\end{array}$ & $\begin{array}{c}0.257 \\
(0.376)\end{array}$ & $\begin{array}{c}0.201 \\
(0.222)\end{array}$ & $\begin{array}{l}0.675^{* *} \\
(0.288)\end{array}$ & $\begin{array}{c}0.143 \\
(0.300)\end{array}$ \\
\hline 30-1 & $\begin{array}{c}1.750^{* * * *} \\
(0.550)\end{array}$ & $\begin{array}{c}1.362 * * * \\
(0.516)\end{array}$ & $\begin{array}{l}1.033^{*} \\
(0.584)\end{array}$ & $\begin{array}{c}1.077^{* * * *} \\
(0.371)\end{array}$ & $\begin{array}{l}0.781^{* *} \\
(0.328)\end{array}$ & $\begin{array}{c}0.585 \\
(0.390)\end{array}$ & $\begin{array}{c}0.674^{* * *} \\
(0.233)\end{array}$ & $\begin{array}{l}0.581^{* *} \\
(0.288)\end{array}$ & $\begin{array}{c}0.448 \\
(0.297)\end{array}$ \\
\hline $\begin{array}{l}\text { Control } \\
\text { group } \\
\text { mean }\end{array}$ & 4.55 & 10.35 & 10.22 & 3.09 & 6.89 & 7.04 & 1.47 & 3.46 & 3.18 \\
\hline Obs. & 12568 & 12464 & 12177 & 12568 & 12464 & 12177 & 12568 & 12464 & 12177 \\
\hline
\end{tabular}

Notes: See notes to Table 3. We estimate the effects of strike exposure without pre-treatment covariates. Robust standard errors in parentheses. ${ }^{* *} p<0.01,{ }^{*} p<0.05$ and ${ }^{*} p<0.10$. 
Table A12 Robustness: Effects of strike exposure on child GP contacts, larger bin size - 35 days

\begin{tabular}{|c|c|c|c|c|c|c|c|c|c|}
\hline & $\begin{array}{c}\text { (1) } \\
\text { Total GP } \\
\text { 1st year }\end{array}$ & $\begin{array}{c}(2) \\
\text { Total GP } \\
\text { 2nd year }\end{array}$ & $\begin{array}{c}(3) \\
\text { Total GP } \\
\text { 3-4 years }\end{array}$ & $\begin{array}{c}\text { (4) } \\
\text { Ordin. GP } \\
\text { 1st year }\end{array}$ & $\begin{array}{c}(5) \\
\text { Ordin. GP } \\
\text { 2nd year }\end{array}$ & $\begin{array}{c}(6) \\
\text { Ordin. GP } \\
\text { 3-4 years }\end{array}$ & $\begin{array}{c}\text { (7) } \\
\text { Emerg. GP } \\
\text { 1st year }\end{array}$ & $\begin{array}{c}\text { (8) } \\
\text { Emerg. GP } \\
\text { 2nd year }\end{array}$ & $\begin{array}{c}\text { (9) } \\
\text { Emerg. GP } \\
\text { 3-4 years }\end{array}$ \\
\hline \multicolumn{10}{|l|}{ Days } \\
\hline $175-141$ & $\begin{array}{c}0.266 \\
(0.476)\end{array}$ & $\begin{array}{c}0.318 \\
(0.472)\end{array}$ & $\begin{array}{c}0.529 \\
(0.557)\end{array}$ & $\begin{array}{c}0.107 \\
(0.318)\end{array}$ & $\begin{array}{c}0.089 \\
(0.294)\end{array}$ & $\begin{array}{c}0.336 \\
(0.363)\end{array}$ & $\begin{array}{c}0.159 \\
(0.209)\end{array}$ & $\begin{array}{c}0.229 \\
(0.271)\end{array}$ & $\begin{array}{c}0.193 \\
(0.291)\end{array}$ \\
\hline $140-106$ & $\begin{array}{c}-0.544 \\
(0.483)\end{array}$ & $\begin{array}{c}-0.334 \\
(0.472)\end{array}$ & $\begin{array}{c}0.189 \\
(0.540)\end{array}$ & $\begin{array}{c}-0.377 \\
(0.323)\end{array}$ & $\begin{array}{c}-0.027 \\
(0.296)\end{array}$ & $\begin{array}{c}0.277 \\
(0.357)\end{array}$ & $\begin{array}{c}-0.168 \\
(0.207)\end{array}$ & $\begin{array}{c}-0.307 \\
(0.270)\end{array}$ & $\begin{array}{c}-0.088 \\
(0.280)\end{array}$ \\
\hline $105-71$ & $\begin{array}{c}0.174 \\
(0.508)\end{array}$ & $\begin{array}{c}0.412 \\
(0.463)\end{array}$ & $\begin{array}{c}0.206 \\
(0.524)\end{array}$ & $\begin{array}{c}0.041 \\
(0.347)\end{array}$ & $\begin{array}{c}0.355 \\
(0.293)\end{array}$ & $\begin{array}{c}0.119 \\
(0.354)\end{array}$ & $\begin{array}{c}0.133 \\
(0.211)\end{array}$ & $\begin{array}{c}0.057 \\
(0.265)\end{array}$ & $\begin{array}{c}0.087 \\
(0.274)\end{array}$ \\
\hline $70-36$ & $\begin{array}{c}0.411 \\
(0.490)\end{array}$ & $\begin{array}{c}1.450 * * * \\
(0.465)\end{array}$ & $\begin{array}{c}0.805 \\
(0.523)\end{array}$ & $\begin{array}{c}0.141 \\
(0.328)\end{array}$ & $\begin{array}{c}0.788^{* * *} \\
(0.298)\end{array}$ & $\begin{array}{c}0.419 \\
(0.348)\end{array}$ & $\begin{array}{c}0.270 \\
(0.205)\end{array}$ & $\begin{array}{l}0.662^{* *} \\
(0.265)\end{array}$ & $\begin{array}{c}0.386 \\
(0.271)\end{array}$ \\
\hline $35-1$ & $\begin{array}{l}1.454^{* * *} \\
(0.512)\end{array}$ & $\begin{array}{c}1.579^{* * *} \\
(0.485)\end{array}$ & $\begin{array}{c}0.977^{*} \\
(0.536)\end{array}$ & $\begin{array}{l}0.875^{* *} \\
(0.346)\end{array}$ & $\begin{array}{c}1.052^{* * *} \\
(0.308)\end{array}$ & $\begin{array}{c}0.552 \\
(0.363)\end{array}$ & $\begin{array}{c}0.579 * * * \\
(0.218)\end{array}$ & $\begin{array}{c}0.527^{*} \\
(0.272)\end{array}$ & $\begin{array}{c}0.425 \\
(0.270)\end{array}$ \\
\hline $\begin{array}{l}\text { Control } \\
\text { group } \\
\text { mean } \\
\text { Observati }\end{array}$ & ns12078 & 10.35 & 10.22 & 12078 & 11982 & 11709 & 12078 & 11982 & 11709 \\
\hline
\end{tabular}


Table A13 Robustness: Effects of strike exposure on child GP contacts, smaller bin size - 21 days

\begin{tabular}{|c|c|c|c|c|c|c|c|c|c|}
\hline & $\begin{array}{c}\text { (1) } \\
\text { Total GP } \\
\text { 1st year }\end{array}$ & $\begin{array}{c}\text { (2) } \\
\text { Total GP } \\
\text { 2nd year }\end{array}$ & $\begin{array}{c}(3) \\
\text { Total GP } \\
\text { 3-4 years }\end{array}$ & $\begin{array}{c}\text { (4) } \\
\text { Ordin. GP } \\
\text { 1st year }\end{array}$ & $\begin{array}{c}\text { (5) } \\
\text { Ordin. GP } \\
\text { 2nd year }\end{array}$ & $\begin{array}{c}\text { (6) } \\
\text { Ordin. GP } \\
\text { 3-4 years }\end{array}$ & $\begin{array}{c}\text { (7) } \\
\text { Emerg. GP } \\
\text { 1st year }\end{array}$ & $\begin{array}{c}\text { (8) } \\
\text { Emerg. GP } \\
\text { 2nd year }\end{array}$ & $\begin{array}{l}\text { (9) } \\
\text { Emerg. GP } \\
\text { 3-4 years }\end{array}$ \\
\hline \multicolumn{10}{|l|}{ Days } \\
\hline 189-169 & $\begin{array}{c}0.886 \\
(0.604)\end{array}$ & $\begin{array}{c}0.00730 \\
(0.599)\end{array}$ & $\begin{array}{c}1.000 \\
(0.683)\end{array}$ & $\begin{array}{c}0.463 \\
(0.407)\end{array}$ & $\begin{array}{c}-0.0659 \\
(0.381)\end{array}$ & $\begin{array}{c}0.534 \\
(0.453)\end{array}$ & $\begin{array}{c}0.423 \\
(0.258)\end{array}$ & $\begin{array}{c}0.0732 \\
(0.340)\end{array}$ & $\begin{array}{c}0.465 \\
(0.356)\end{array}$ \\
\hline $168-148$ & $\begin{array}{c}0.736 \\
(0.605)\end{array}$ & $\begin{array}{c}0.373 \\
(0.615)\end{array}$ & $\begin{array}{c}0.442 \\
(0.722)\end{array}$ & $\begin{array}{c}0.501 \\
(0.411)\end{array}$ & $\begin{array}{c}0.0792 \\
(0.378)\end{array}$ & $\begin{array}{c}0.417 \\
(0.470)\end{array}$ & $\begin{array}{c}0.235 \\
(0.258)\end{array}$ & $\begin{array}{c}0.294 \\
(0.353)\end{array}$ & $\begin{array}{c}0.0249 \\
(0.379)\end{array}$ \\
\hline $147-127$ & $\begin{array}{c}0.293 \\
(0.622)\end{array}$ & $\begin{array}{c}0.491 \\
(0.609)\end{array}$ & $\begin{array}{c}0.324 \\
(0.717)\end{array}$ & $\begin{array}{c}0.297 \\
(0.409)\end{array}$ & $\begin{array}{c}0.437 \\
(0.384)\end{array}$ & $\begin{array}{c}0.422 \\
(0.474)\end{array}$ & $\begin{array}{c}-0.00421 \\
(0.277)\end{array}$ & $\begin{array}{c}0.0540 \\
(0.346)\end{array}$ & $\begin{array}{l}-0.0976 \\
(0.362)\end{array}$ \\
\hline 126-106 & $\begin{array}{c}-0.134 \\
(0.613)\end{array}$ & $\begin{array}{c}-0.409 \\
(0.600)\end{array}$ & $\begin{array}{c}0.584 \\
(0.691)\end{array}$ & $\begin{array}{c}-0.146 \\
(0.419)\end{array}$ & $\begin{array}{c}-0.0567 \\
(0.381)\end{array}$ & $\begin{array}{c}0.500 \\
(0.461)\end{array}$ & $\begin{array}{r}0.0122 \\
(0.249)\end{array}$ & $\begin{array}{c}-0.353 \\
(0.337)\end{array}$ & $\begin{array}{c}0.0844 \\
(0.368)\end{array}$ \\
\hline $105-85$ & $\begin{array}{c}0.657 \\
(0.650)\end{array}$ & $\begin{array}{c}0.731 \\
(0.587)\end{array}$ & $\begin{array}{c}0.297 \\
(0.670)\end{array}$ & $\begin{array}{c}0.383 \\
(0.440)\end{array}$ & $\begin{array}{c}0.504 \\
(0.377)\end{array}$ & $\begin{array}{c}0.198 \\
(0.454)\end{array}$ & $\begin{array}{c}0.274 \\
(0.279)\end{array}$ & $\begin{array}{c}0.227 \\
(0.338)\end{array}$ & $\begin{array}{l}0.0991 \\
(0.353)\end{array}$ \\
\hline $84-64$ & $\begin{array}{c}0.693 \\
(0.643)\end{array}$ & $\begin{array}{c}0.260 \\
(0.606)\end{array}$ & $\begin{array}{c}0.583 \\
(0.676)\end{array}$ & $\begin{array}{c}0.344 \\
(0.444)\end{array}$ & $\begin{array}{c}0.259 \\
(0.387)\end{array}$ & $\begin{array}{c}0.400 \\
(0.461)\end{array}$ & $\begin{array}{c}0.349 \\
(0.256)\end{array}$ & $\begin{array}{c}0.00154 \\
(0.333)\end{array}$ & $\begin{array}{c}0.183 \\
(0.347)\end{array}$ \\
\hline $63-43$ & $\begin{array}{c}1.082^{*} \\
(0.627)\end{array}$ & $\begin{array}{c}1.740^{* * *} \\
(0.595)\end{array}$ & $\begin{array}{c}0.965 \\
(0.675)\end{array}$ & $\begin{array}{c}0.629 \\
(0.423)\end{array}$ & $\begin{array}{c}1.053^{* * *} \\
(0.388)\end{array}$ & $\begin{array}{c}0.607 \\
(0.454)\end{array}$ & $\begin{array}{c}0.453^{*} \\
(0.260)\end{array}$ & $\begin{array}{l}0.687^{* *} \\
(0.336)\end{array}$ & $\begin{array}{c}0.358 \\
(0.349)\end{array}$ \\
\hline $42-22$ & $\begin{array}{c}0.527 \\
(0.636)\end{array}$ & $\begin{array}{c}1.759 * * * \\
(0.620)\end{array}$ & $\begin{array}{l}1.435^{* *} \\
(0.697)\end{array}$ & $\begin{array}{c}0.245 \\
(0.426)\end{array}$ & $\begin{array}{c}1.172^{* * *} \\
(0.393)\end{array}$ & $\begin{array}{c}0.869 * \\
(0.459)\end{array}$ & $\begin{array}{c}0.282 \\
(0.274)\end{array}$ & $\begin{array}{c}0.588^{*} \\
(0.347)\end{array}$ & $\begin{array}{c}0.566 \\
(0.363)\end{array}$ \\
\hline $21-1$ & $\begin{array}{c}2.638 * * * \\
(0.665)\end{array}$ & $\begin{array}{c}1.749 * * * \\
(0.623)\end{array}$ & $\begin{array}{c}1.163^{*} \\
(0.701)\end{array}$ & $\begin{array}{c}1.687^{* * *} \\
(0.453)\end{array}$ & $\begin{array}{l}0.942 * * \\
(0.396)\end{array}$ & $\begin{array}{c}0.567 \\
(0.481)\end{array}$ & $\begin{array}{c}0.951^{* * *} \\
(0.277)\end{array}$ & $\begin{array}{l}0.807^{* *} \\
(0.350)\end{array}$ & $\begin{array}{c}0.596^{*} \\
(0.349)\end{array}$ \\
\hline $\begin{array}{l}\text { Control } \\
\text { group } \\
\text { mean } \\
\text { Observatio }\end{array}$ & ns12078 & 10.35 & 10.22 & 12078 & 6.89 & 11709 & 12078 & 11982 & 11709 \\
\hline
\end{tabular}


Table A14 Placebo test: The effect of strike exposure on child health measured as accumulated GP contacts by type, data for the two control years 2009 and 2010

\begin{tabular}{|c|c|c|c|c|c|c|}
\hline & $\begin{array}{c}(1) \\
\text { Total GP } \\
\text { 1st year }\end{array}$ & $\begin{array}{c}(2) \\
\text { Total GP } \\
\text { 2-4 years }\end{array}$ & $\begin{array}{c}\text { (3) } \\
\text { Ordin. GP } \\
\text { 1st year }\end{array}$ & $\begin{array}{c}(4) \\
\text { Ordin. GP } \\
\text { 2-4 years }\end{array}$ & $\begin{array}{c}\text { (5) } \\
\text { Emerg. GP } \\
\text { 1st year }\end{array}$ & $\begin{array}{c}\text { (6) } \\
\text { Emerg. GP } \\
\text { 2-4 years }\end{array}$ \\
\hline \multicolumn{7}{|l|}{ Days } \\
\hline 180-151 & $\begin{array}{c}0.270 \\
(0.621)\end{array}$ & $\begin{array}{l}-0.505 \\
(1.097)\end{array}$ & $\begin{array}{l}-0.076 \\
(0.411)\end{array}$ & $\begin{array}{c}0.153 \\
(0.696)\end{array}$ & $\begin{array}{c}0.346 \\
(0.267)\end{array}$ & $\begin{array}{c}-0.658 \\
(0.589)\end{array}$ \\
\hline $150-$ & $\begin{array}{c}-0.154 \\
(0.623)\end{array}$ & $\begin{array}{c}-1.188 \\
(1.084)\end{array}$ & $\begin{array}{r}-0.455 \\
(0.399)\end{array}$ & $\begin{array}{c}-0.968 \\
(0.670)\end{array}$ & $\begin{array}{c}0.300 \\
(0.284)\end{array}$ & $\begin{array}{c}-0.220 \\
(0.599)\end{array}$ \\
\hline $120-91$ & $\begin{array}{l}-0.990 \\
(0.637)\end{array}$ & $\begin{array}{c}0.315 \\
(1.096)\end{array}$ & $\begin{array}{c}-1.019 * * \\
(0.414)\end{array}$ & $\begin{array}{c}0.632 \\
(0.691)\end{array}$ & $\begin{array}{c}0.029 \\
(0.282)\end{array}$ & $\begin{array}{c}-0.317 \\
(0.592)\end{array}$ \\
\hline 90-61 & $\begin{array}{c}-0.341 \\
(0.629)\end{array}$ & $\begin{array}{c}0.678 \\
(1.089)\end{array}$ & $\begin{array}{c}-0.387 \\
(0.420)\end{array}$ & $\begin{array}{c}0.651 \\
(0.688)\end{array}$ & $\begin{array}{c}0.047 \\
(0.265)\end{array}$ & $\begin{array}{c}0.027 \\
(0.585)\end{array}$ \\
\hline 60-31 & $\begin{array}{c}0.032 \\
(0.634)\end{array}$ & $\begin{array}{c}-0.494 \\
(1.083)\end{array}$ & $\begin{array}{c}0.057 \\
(0.415)\end{array}$ & $\begin{array}{c}0.054 \\
(0.694)\end{array}$ & $\begin{array}{c}-0.025 \\
(0.279)\end{array}$ & $\begin{array}{c}-0.548 \\
(0.583)\end{array}$ \\
\hline $30-1$ & $\begin{array}{c}-0.991 \\
(0.623)\end{array}$ & $\begin{array}{l}-0.529 \\
(1.069)\end{array}$ & $\begin{array}{c}-0.863^{* *} \\
(0.417)\end{array}$ & $\begin{array}{c}0.114 \\
(0.699)\end{array}$ & $\begin{array}{c}-0.129 \\
(0.263)\end{array}$ & $\begin{array}{c}-0.643 \\
(0.552)\end{array}$ \\
\hline $\begin{array}{l}\text { Control } \\
\text { group mean }\end{array}$ & 4.55 & 20.65 & 3.09 & 13.98 & 1.47 & 6.67 \\
\hline Obs. & 8203 & 7941 & 8203 & 7941 & 8203 & 7941 \\
\hline \multicolumn{7}{|c|}{$\begin{array}{l}\text { Notes: Each column shows the estimates from separate regressions. The coefficients are for } \\
\text { theinteractions of } 30 \text { day bins and a strikeindicator. All regressions include period and bin } \\
\text { fixed effects, as well as control variables (seenotes forTable3). Thesampleincludes children } \\
\text { who were born in Copenhagen in the placebo treated period (September 17, } 2008 \text { - April 15, } \\
\text { 2009) and in control period (September 17, } 2009 \text { - April 15, 2010). Robust standard errors } \\
\text { in parentheses. }{ }^{* *} p<0.01,{ }^{*} p<0.05 \text { and }{ }^{*} p<0.10 \text {. }\end{array}$} \\
\hline
\end{tabular}


Table A15 Effect of strike exposure on child and mother health measured as accumulated and yearly total GP fees, Euro

\begin{tabular}{|c|c|c|c|c|}
\hline & $\begin{array}{c}\text { (1) } \\
\text { Total GP } \\
\text { mother and child } \\
\text { 1st year }\end{array}$ & $\begin{array}{c}\text { (2) } \\
\text { Total GP } \\
\text { mother and child } \\
\text { 2nd year }\end{array}$ & $\begin{array}{c}\text { (3) } \\
\text { Total GP } \\
\text { mother and child } \\
\text { 3-4 years }\end{array}$ & $\begin{array}{c}\text { (4) } \\
\text { Total GP } \\
\text { mother and child } \\
<4 \mathrm{y}\end{array}$ \\
\hline \multicolumn{5}{|l|}{ Days } \\
\hline $180-151$ & $\begin{array}{c}8.586 \\
(14.174)\end{array}$ & $\begin{array}{c}9.741 \\
(13.573)\end{array}$ & $\begin{array}{c}17.876 \\
(19.877)\end{array}$ & $\begin{array}{c}33.850 \\
(39.289)\end{array}$ \\
\hline $150-121$ & $\begin{array}{c}10.476 \\
(13.846)\end{array}$ & $\begin{array}{l}29.762^{* *} \\
(13.437)\end{array}$ & $\begin{array}{c}30.077 \\
(19.355)\end{array}$ & $\begin{array}{c}66.267^{*} \\
(38.443)\end{array}$ \\
\hline $120-91$ & $\begin{array}{c}0.230 \\
(14.013)\end{array}$ & $\begin{array}{c}15.548 \\
(13.329)\end{array}$ & $\begin{array}{c}1.902 \\
(18.994)\end{array}$ & $\begin{array}{c}12.530 \\
(37.556)\end{array}$ \\
\hline $90-61$ & $\begin{array}{c}8.850 \\
(14.388)\end{array}$ & $\begin{array}{c}40.319 * * * \\
(13.619)\end{array}$ & $\begin{array}{c}37.636^{*} \\
(19.205)\end{array}$ & $\begin{array}{l}87.099 * * \\
(38.453)\end{array}$ \\
\hline $60-31$ & $\begin{array}{c}14.918 \\
(14.229)\end{array}$ & $\begin{array}{c}52.904^{* * *} \\
(13.726)\end{array}$ & $\begin{array}{c}31.088 \\
(19.487)\end{array}$ & $\begin{array}{l}94.165^{* *} \\
(39.242)\end{array}$ \\
\hline $30-1$ & $\begin{array}{l}46.565^{* * *} \\
(14.761)\end{array}$ & $\begin{array}{c}61.200 * * * \\
(13.752)\end{array}$ & $\begin{array}{l}48.826 * * \\
(19.190)\end{array}$ & $\begin{array}{c}154.281^{* * *} \\
(39.327)\end{array}$ \\
\hline $\begin{array}{l}\text { Control } \\
\text { group mean }\end{array}$ & 240.22 & 307.22 & 426.41 & 978.01 \\
\hline Obs. & 12078 & 11982 & 11709 & 11698 \\
\hline
\end{tabular}

Notes: See notes for Table3. GP fees are measured in Euro (2015-prices). Robust standard errors in parentheses. ${ }^{* *} p<0.01,{ }^{* *} p<0.05$ and ${ }^{*} p<0.10$. 